\title{
Quaternary sea-level history of the United States
}

\author{
Daniel R. Muhs ${ }^{1}$, John F. Wehmiller ${ }^{2}$, Kathleen R. Simmons ${ }^{1}$ and Linda L. York ${ }^{3}$ \\ ${ }^{1}$ U.S. Geological Survey, MS 980, Box 25046, Federal Center, Denver, CO 80225, USA \\ 2 Department of Geology, University of Delaware, Newark, DE 19716, USA \\ ${ }^{3}$ U.S. National Park Service, Southeast Regional Office, 100 Alabama St. S.W., Atlanta, GA 30303, USA
}

\section{Introduction}

In the past 30 years, there have been tremendous advances in our understanding of Quaternary sea-level history, due directly to developments in Quaternary dating methods, particularly uranium-series disequilibrium and amino acid racemization. Another reason for this progress is that coastline history can now be tied to the oxygen-isotope record of foraminifera in deep-sea cores. Furthermore, both records have been linked to climate change on the scale of glacialinterglacial cycles that are thought to be forced by changes in Earth-Sun geometry, or "orbital forcing" (Milankovitch, 1941).

Prior to about 1965 , much less was known about the Quaternary sea-level record of the United States. Knowledge of the Quaternary history of U.S. coastlines at that time has been summarized by Richards \& Judson (1965) for the Atlantic coast, Bernard \& LeBlanc (1965) for the Gulf coast, Wahrhaftig \& Birman (1965) for the Pacific coast, Péwé et al. (1965) for Alaska, and Curray (1965) for the continental shelves. On many segments of U.S. coastlines, Quaternary shorelines had not even been mapped adequately. Although marine terrace maps were available for small reaches of coast (e.g. the California studies of Alexander, 1953; Vedder \& Norris, 1963; Woodring et al., 1946), much larger areas had not been studied in sufficient detail for understanding sea-level history. The oxygen-isotope composition of foraminifera in deep-sea sediments had been explored (Emiliani, 1955) and the cores partially dated (Rosholt et al., 1961), but the relations of this record to ice volume and the sea-level record were not understood. At that time, no reliable dating method beyond the range of radiocarbon was fully developed; some of the first attempts at U-series dating of marine fossils had just been published (Broecker \& Thurber, 1965; Osmond et al., 1965).

The direct dating of emergent marine deposits is possible because $\mathrm{U}$ is dissolved in ocean water but $\mathrm{Th}$ and $\mathrm{Pa}$ are not. Certain marine organisms, particularly corals (but not mollusks), co-precipitate U directly from seawater during growth. All three of the naturally occurring isotopes of $\mathrm{U},{ }^{238} \mathrm{U}$ and ${ }^{235} \mathrm{U}$ (both primordial parents), and ${ }^{234} \mathrm{U}$ (a decay product of ${ }^{238} \mathrm{U}$ ), are therefore incorporated into living corals. ${ }^{238} \mathrm{U}$ decays to ${ }^{234} \mathrm{U}$, which in turn decays to ${ }^{230} \mathrm{Th}$. The parent isotope ${ }^{235} \mathrm{U}$ decays to ${ }^{231} \mathrm{~Pa}$. Thus, activity ratios of ${ }^{230} \mathrm{Th} /{ }^{234} \mathrm{U}$, ${ }^{234} \mathrm{U} /{ }^{238} \mathrm{U}$, and ${ }^{231} \mathrm{~Pa} /{ }^{235} \mathrm{U}$ can provide three independent clocks for dating the same fossil coral (e.g. Edwards et al., 1997; Gallup et al., 2002). Until the 1980s, U-series dating was done by alpha spectrometry. Most workers since that time have employed thermal-ionization mass spectrometry (TIMS) to measure U-series nuclides, which has increased precision, requires much smaller samples, and can extend the useful time period for dating back to at least $\sim 500,000 \mathrm{yr}$.

Because corals are not found in all marine deposits, amino-acid racemization has provided a complementary method for geochronology of coastal records (see review by Wehmiller \& Miller, 2000). The basis of amino-acid geochronology is that proteins of living organisms (such as marine mollusks) contain only amino acids of the $L$ configuration. Upon the death of an organism, amino acids of the $L$ configuration convert to amino acids of the $D$ configuration, a process called racemization. Racemization is a reversible reaction that results in increased $D / L$ ratios in a fossil through time until an equilibrium ratio (1.00-1.30, depending on the amino acid) is reached. Racemization kinetics are nonlinear and are a function of environmental temperature history and taxonomy. Amino-acid methods are best applied to fossil mollusks, which occur on virtually every coastline of the world. Although numerical age estimates from amino-acid ratios are still tentative, the technique provides a valuable correlation tool that works best when combined with numerical methods such as U-series or ${ }^{14} \mathrm{C}$ dating.

The sea-level record of Quaternary glacial and interglacial periods is reflected in the oxygen-isotope composition (relative amounts of ${ }^{16} \mathrm{O}$ and ${ }^{18} \mathrm{O}$ ) of foraminifera in deep-sea sediments. Oxygen-isotope compositions of foraminifera are a function of both water temperature and the oxygen isotope composition of ocean water at the time of shell formation. Foraminifera precipitate shells with more ${ }^{18} \mathrm{O}$ in colder water. The oxygen isotope composition of ocean water is a function of the mass of glacier ice on land, because glacier ice is enriched in ${ }^{16} \mathrm{O}$. Thus, relatively heavy $\left({ }^{18} \mathrm{O}\right.$-enriched) oxygen isotope compositions in foraminifera reflect glacial periods, whereas light compositions $\left({ }^{16} \mathrm{O}\right.$ enriched) reflect interglacial periods (Fig. 1). Two difficulties arise with the intepretation of the oxygen-isotope record for sea-level studies, however: (1) it is difficult to decouple the ice-volume (or sea-level) component of oxygen-isotope composition from the water temperature component; and (2) deep-sea sediments can rarely be dated directly with any precision.

Coastal landforms and deposits provide an independent record of sea-level history. Constructional reefs or wave-cut terraces (Fig. 2) form when they can keep up with rising sea level (reefs) or when they can be cut into bedrock during a stable high sea stand (wave-cut terraces). Thus, emergent marine deposits, either reefs or terraces, on a tectonically 


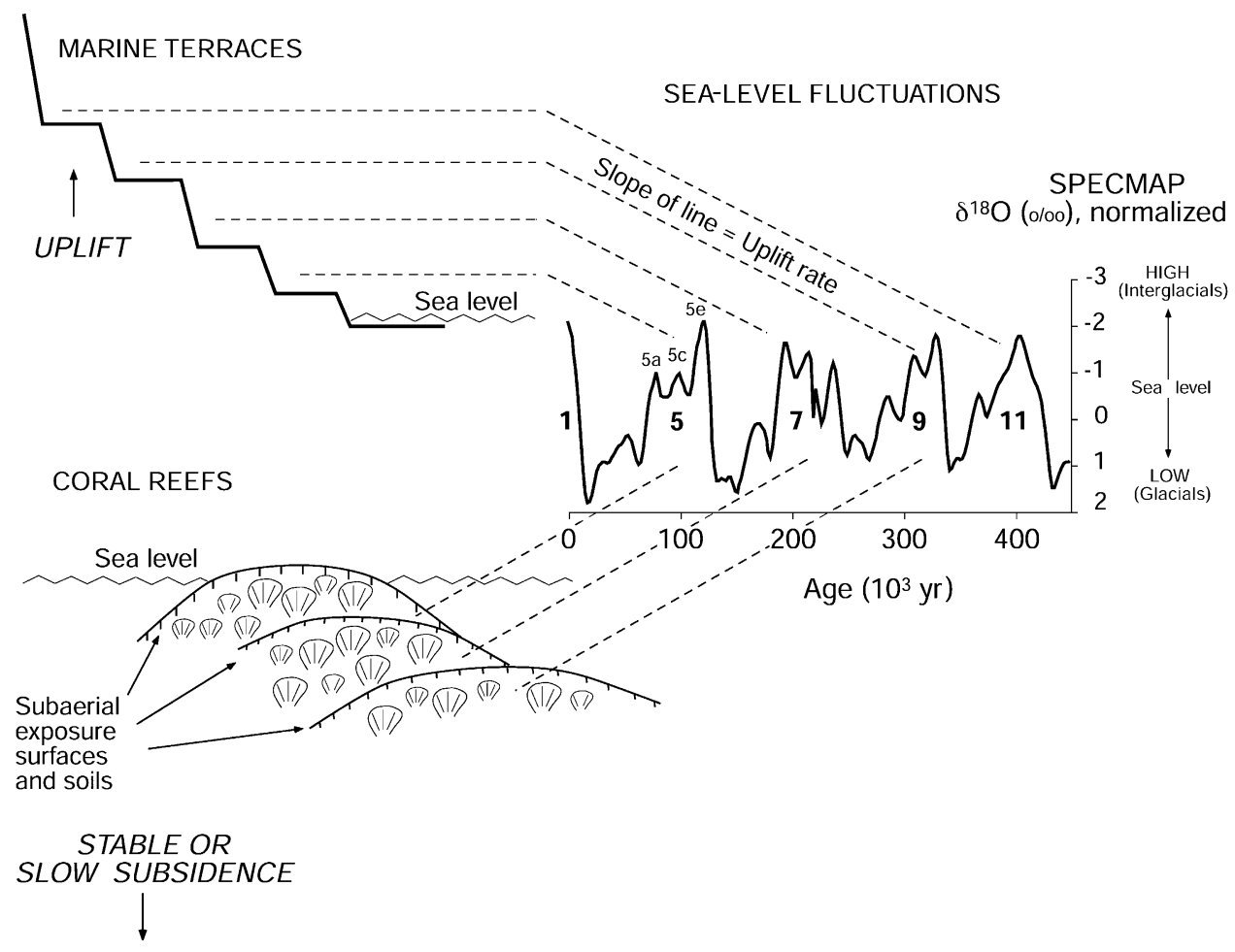

Fig. 1. Diagram of hypothetical coastlines showing relations of oxygen isotope records in foraminifera of deep-sea sediments to emergent reef or wave-cut terraces on an uplifting coastline (upper) and a tectonically stable or slowly subsiding coastline (lower). Emergent marine deposits record interglacial periods. Oxygen-isotope data shown are from the SPECMAP record (Imbrie et al., 1984).

active, uplifting coastline record interglacial periods (Fig. 1). On a tectonically stable or slowly subsiding coast, reefs will be emergent only from sea-level stands that were higher than present (Fig. 1). Paleo-sea levels can thus be determined from tectonically stable coastlines or even uplifting coastlines, if reasoned models of uplift rate can be made. Low stands of sea that occurred during glacial periods may also form reefs or wave-cut terraces, but such features will be offshore, whether on rising, stable or subsiding coasts. Coastal landforms have two advantages over the oxygen isotope record for sea-level history: (1) if corals are present, they can be dated directly; and (2) depending on the tectonic setting, estimates of paleo-sea level can be made.

A new framework for sea-level studies began with a seminal paper on U-series dating that linked the deep-sea oxygen isotope record with uplifted interglacial coral terraces of Barbados (Broecker et al., 1968). These two independently dated records were, in turn, linked to the Milankovitch (1941), or astronomical (orbital forcing) theory of climate change. In the past three decades, geologists have compared a fragmentary geomorphic record (terraces) with a nearly complete record (deep-sea sediments) of Quaternary cycles of glaciations and interglaciations (Aharon \& Chappell, 1986; Bender et al., 1979; Bloom et al., 1974; Chappell, 1974a; Chappell \& Shackleton, 1986; Dodge et al., 1983; $\mathrm{Ku}, 1968 ; \mathrm{Ku}$ et al., 1990; Mesolella et al., 1969; Veeh \& Chappell, 1970). Most of these pioneering studies concentrated on the spectacular flights of tectonically uplifted interglacial coral terraces on the islands of Barbados and New Guinea. Nevertheless, the coastlines of the United States also have abundant interglacial terraces and reefs and many localities have now been studied in detail (Fig. 3).

There have been far fewer studies of sea-level lowering on the coasts of the United States during glacial periods. The magnitude of sea-level lowering during the last glacial period has been debated for more than 160 years (see review in Bloom, 1983a). In fact, Bloom (1983a) points out that even at the time of his own review, little progress had been made in estimating the amount of last-glacial sea-level lowering since the studies of the previous century. However, in the 20 years since Bloom's (1983a, b) review, much progress has been made in estimating the magnitude of sea-level lowering during the last glacial period and subsequent sea-level rise in the Holocene. Many of the most recent estimates of sea-level lowering during the last glacial period are summarized in Fleming et al. (1998), Yokoyama et al. (2001) and Clark \& Mix (2002).

The geologic record of late-glacial and Holocene sea-level history is complicated by differential glacio-hydro-isostatic responses of the Earth's crust. Models by Walcott (1972), Chappell (1974b), Clark et al. (1978), Nakata \& Lambeck (1989), Mitrovica \& Peltier (1991), and Peltier (1994, 1996, 1999, 2002) suggest that different sea-level records should be expected on continental coasts and mid-oceanic islands 
FLORIDA-BAHAMAS TYPE:

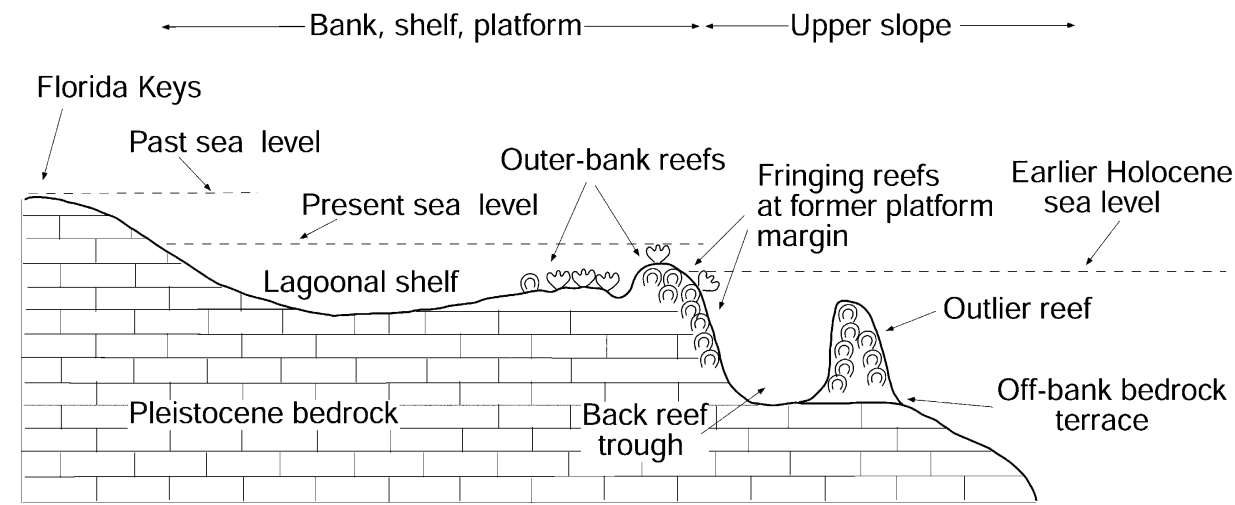

\section{CALIFORNIA-OREGON TYPE:}

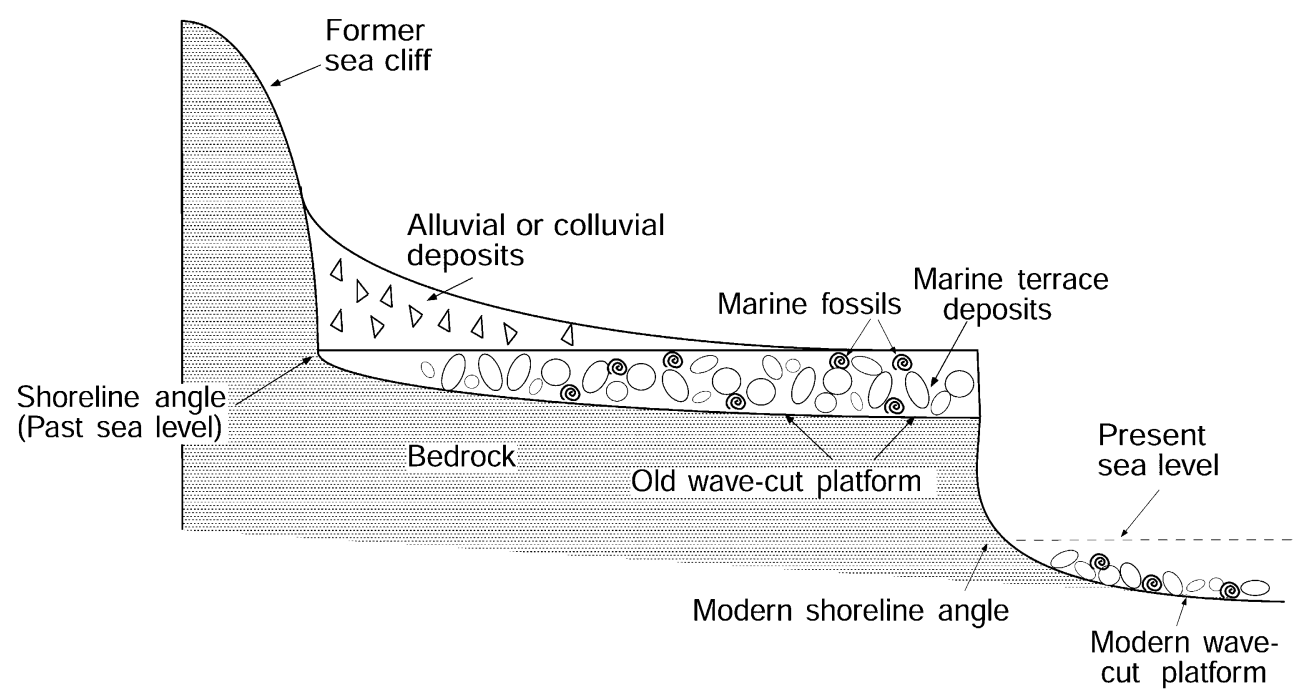

Fig. 2. Cross-sections showing idealized geomorphic and stratigraphic expression of coastal landforms and deposits found on low-wave-energy carbonate coasts of Florida and the Bahamas (upper) and high-wave-energy rocky coasts of Oregon and California (lower). Florida-Bahamas configuration redrawn from Lidz et al. (1997); Oregon-California type redrawn from Muhs (2000).

at different latitudes. During glacial periods, continental ice sheets depress the Earth's crust, with an associated forebulge at their margins. As the ice recedes, formerly glaciated regions experience rebound, or crustal uplift. As sea level rises during deglaciation, the additional water mass in the ocean basins causes crustal loading and depression at continental margins. Chappell (1974b) and Nakata \& Lambeck (1989) proposed that the same meltwater loading on ocean floors would bring about mantle flow (below the sea floor) towards islands of some minimum size distant from former ice sheets. Thus, such islands would experience uplift and should have evidence of emergent Holocene shorelines. Some of the glacio-hydro-isostatic models of Holocene sea-level history have been tested on tropical islands of the United States.
In this paper, we review some of the accomplishments in understanding Quaternary sea-level fluctuations as recorded on the coastlines of the United States. It is necessarily an incomplete review, in part because of space limitations and in part because much of the research of the past three decades has focused on specific time periods. Thus, much of our emphasis is on the sea-level record of the last interglacial complex (defined informally here as those high sea stands represented by all of oxygen isotope stage 5). Nevertheless, we touch on progress made in understanding the U.S. record of pre-late Quaternary sea-level stands, as well as sea-level changes during the last glacial period and the Holocene. Because the sea-level record in the U.S. differs geographically, our discussion is arranged in that manner (Fig. 3). 


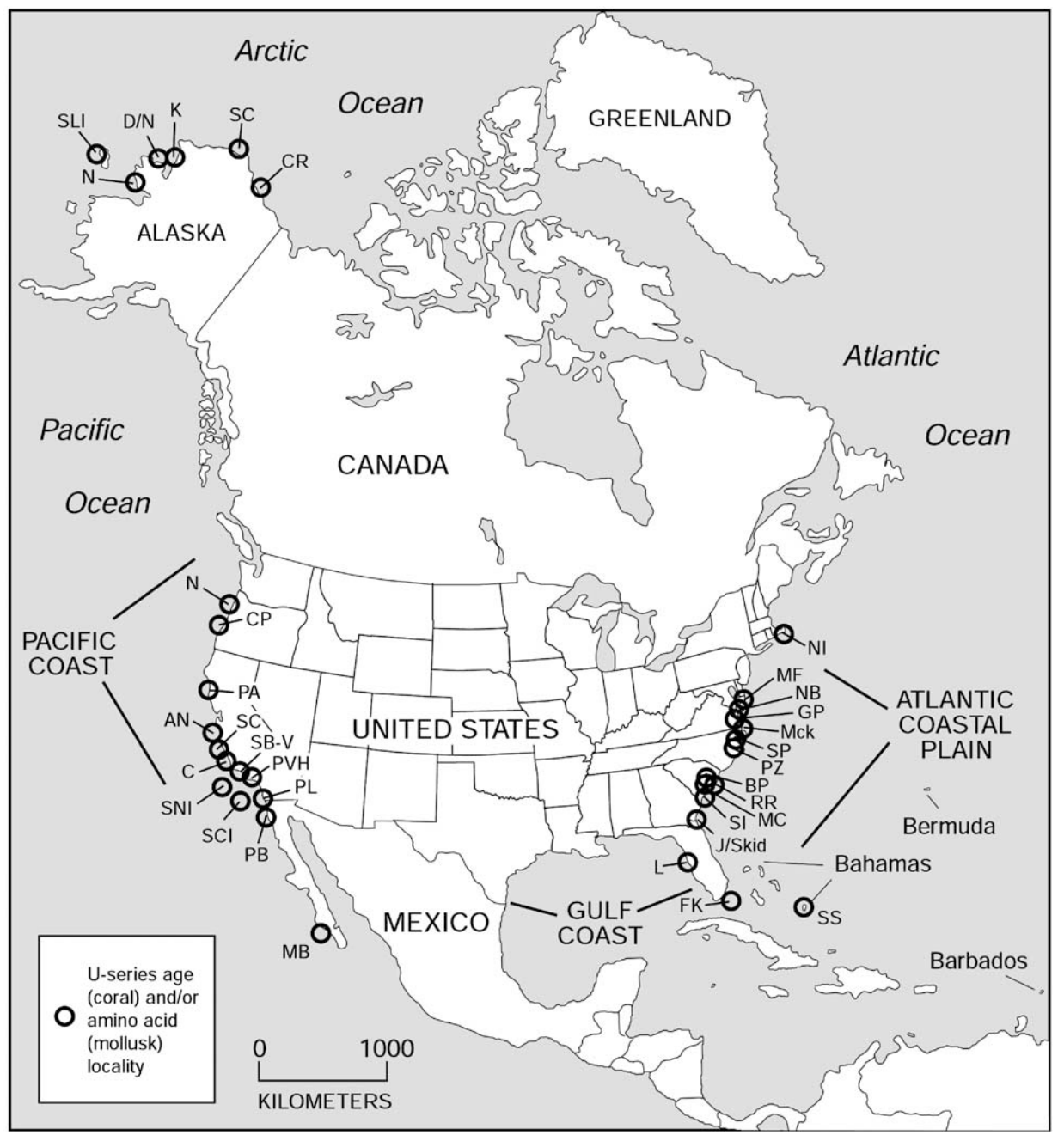

Fig. 3. Map of North America showing localities referred to in the text. Abbreviations: CR, Colville River; SC, Skull Cliff; K, Krusenstern; D/N, Deering/Nugnugaluktuk; SLI, St. Lawrence Island; N, Nome; NE, Newport; CP, Coquille Point; PA, Point Arena; AN, Point Año Nuevo; SC, Point Santa Cruz; C, Cayucos; SB-V, Santa Barbara-Ventura area; SNI, San Nicolas Island; SCI, San Clemente Island; PVH, Palos Verdes Hills; PL, Point Loma; PB, Punta Banda; MB, Magdalena Bay; NI, Nantucket Island; MF, Matthews Field; NB, Norris Bridge; GP, Gomez Pit,; Mck, Moyock; SP, Stetson Pit; PZ, Ponzer; BP, Berkeley Pit; RR, Rifle Range Pit; MC, Mark Clark Pit; SI, Scanawah Island; J/Skid, Jones Pit, Skidway Island; FK, Florida Keys; SS, San Salvador Island.

\section{Florida}

Southern Florida, and particularly the Florida Keys island chain (Fig. 4), is an important area for sea-level history because the region is tectonically stable, records of past sealevel stands are abundant, and materials suitable for dating by both uranium-series and radiocarbon methods are available. Because this platform represents long-term carbonate sedimentation on a passive continental margin, late Quaternary marine deposits on the Florida Keys have not experienced significant uplift, subsidence, or tectonic deformation.

Islands of the Florida Keys are important for Quaternary sea-level history because stratigraphic studies indicate that multiple episodes of reef growth and carbonate rock formation have taken place there (Halley et al., 1997). The upper (north- eastern) keys are composed of the Key Largo Limestone, a coral-dominated Quaternary carbonate rock (Coniglio \& Harrison, 1983; Harrison \& Coniglio, 1985; Hoffmeister et al., 1967; Hoffmeister \& Multer, 1968). The lower (southwestern) keys are composed of the Miami Limestone, a dominantly oolitic marine carbonate rock. Important sea level records have also been found offshore from the Florida Keys (Lidz et al., 1991, 1997). Stratigraphic studies by Enos \& Perkins (1977) and Multer et al. (2002) show that the Key Largo Limestone consists of five distinct, coral-dominated Quaternary limestones, from oldest to youngest, Q1 through Q5 (Fig. 5). The five units are separated by discontinuity surfaces, recognizable by subaerial laminated crusts (calcretes), root structures, solution surfaces and either soils or soil breccias. 

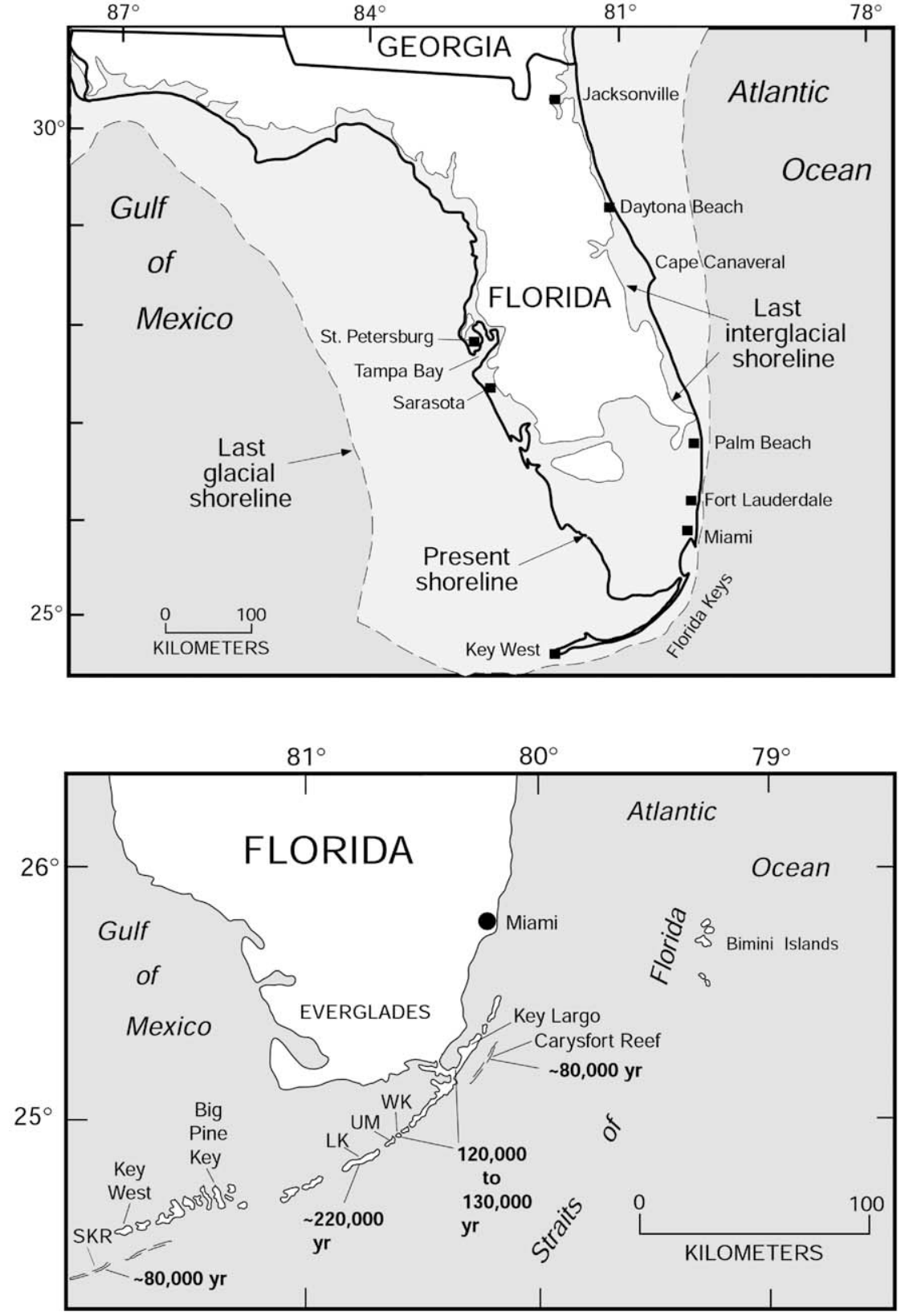

Fig. 4. Upper: map of the State of Florida, showing the modern, last glacial $(\sim 21,000 y r)$, and last-interglacial $(\sim 120,000 y r)$ shorelines. Estimated position of last-interglacial shoreline generated using 1:250,000-scale topographic maps and an assumed $+6 m$ sea-level position, relative to present; estimated position of last-glacial shoreline generated using 1:750,000 topographic map and an assumed $-120 \mathrm{~m}$ sea-level position, relative to present. Lower: detail of southern Florida, including the Florida Keys, and U-series ages of emergent or shallow-submerged Pleistocene reefs. Abbreviations: WK, Windley Key, UM, Upper Matecumbe Key; LK, Long Key; SKR, Sand Key Reef. Age data from Ludwig et al. (1996), Toscano \& Lundberg (1999), Fruijtier et al. (2000), Multer et al. (2002) and this paper.
Florida Keys: Mid-Pleistocene Interglacial High Sea Stands

Recent studies by Multer et al. (2002) and the present authors have yielded some fragmentary evidence of the timing and magnitude of sea-level rise during interglacial high sea stands of the mid Pleistocene. Multer et al. (2002) reported U-series ages of $\sim 370,000 \mathrm{yr}$ for a coral (Montastrea annularis) from the Q3 unit drilled from a locality called Pleasant Point in Florida Bay. Although unrecrystallized, this coral showed clear evidence of open-system conditions and the age is probably closer to $300,000-340,000 \mathrm{yr}$ ago, if the opensystem model of Gallup et al. (1994) is correct. Nevertheless, the age and elevation of this reef suggest that sea level was close to present during marine oxygen isotope stage (MIS) 9, in agreement with recent data from tectonically stable Henderson Island in the South Pacific (Stirling et al., 2001).

The Q4 unit on the Florida Keys has not received much attention from geochronologists. We collected samples of near-surface Montastrea annularis corals in quarry spoil piles that may date to this unit on Long Key. Analysis of a single sample shows a $U$ content of $2.7 \mathrm{ppm}, \mathrm{a}{ }^{230} \mathrm{Th} /{ }^{232} \mathrm{Th}$ ratio of $\sim 14,000$, a back-calculated initial ${ }^{234} \mathrm{U} /{ }^{238} \mathrm{U}$ value of 1.190 and an apparent age of $235,000 \pm 4000 \mathrm{yr}$. The higher-than-modern initial ${ }^{234} U /{ }^{238} U$ value indicates a probable bias to an older age of ca. $7000 \mathrm{yr}$; thus, the true age may be closer to $\sim 220,000-230,000 \mathrm{yr}$. If so, these data suggest that sea level also stood near present during MIS 7, the penultimate interglacial period. 


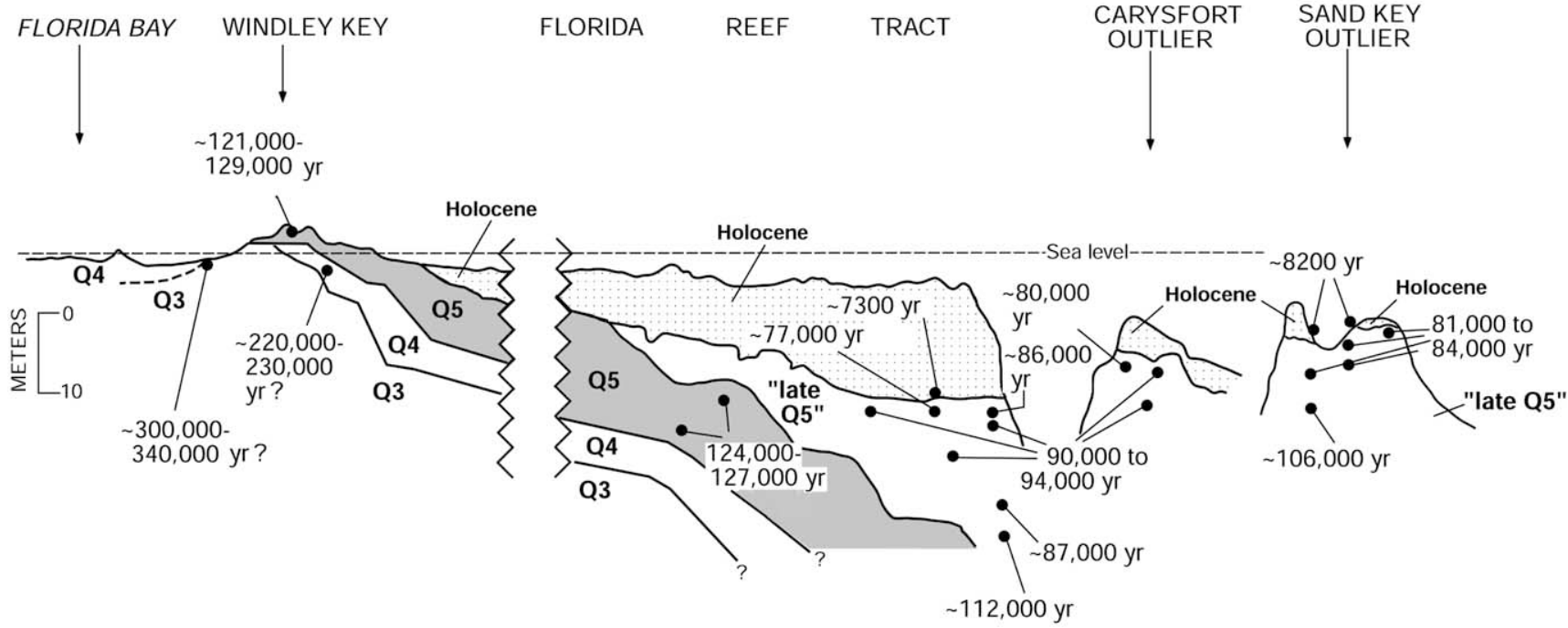

Fig. 5. Composite cross-section of the Florida Keys from northwest to southeast and U-series ages of corals from Quaternary reefs. Redrawn from Multer et al. (2002).

\section{Florida Keys: The Last Interglacial Period}

Early studies showed that the Miami Limestone and the uppermost part of the Key Largo Limestone (the Q5 unit) probably date to the peak of the last interglacial period (Broecker \& Thurber, 1965; Osmond et al., 1965). More recent U-series studies by Fruijtier et al. (2000) using TIMS methods have confirmed these age estimates, at least for the Key Largo Limestone. These workers reported new ages for corals from Windley Key, Upper Matecumbe Key, and Key Largo that, when corrected for high initial ${ }^{234} \mathrm{U} /{ }^{238} \mathrm{U}$ values (Gallup et al., 1994), range from about $\sim 130,000$ to $121,000 \mathrm{yr}$. Multer $\mathrm{et} \mathrm{al}$. (2002) also showed, through an extensive series of cores, that the Q5 unit slopes downward to the southeast but can be traced laterally offshore (Fig. 5). They reported TIMS U-series ages of $\sim 124,000$ and $\sim 127,000 \mathrm{yr}$ for corals from the Q5 unit at water depths of $\sim 16$ and $\sim 22 \mathrm{~m}$, respectively. All these ages are in agreement with other records of peak last-interglacial corals (e.g. Chen et al., 1991; Edwards et al., 1997; Gallup et al., 1994; Muhs et al., 2002a, b).

The Florida Keys contain some of the best evidence that sea level during the peak of the last interglacial period must have been higher than present, because the region is tectonically stable. The youngest (Q5) unit of the Key Largo Limestone at Windley Key is 3-5 $\mathrm{m}$ above present sea level, on Grassy Key it is 1-2 m above sea level, and on Key Largo it is $3-4 \mathrm{~m}$ above sea level. Based on the elevations of the Key Largo Limestone at Windley Key and Key Largo and optimum growth depths of corals in the formation (Shinn et al., 1989; Stanley, 1966), sea level during the last interglacial period (MIS 5e) must have been at least 5-8 $\mathrm{m}$ above present. An inference of a higher-than-present sea level on the Florida Keys during the last interglacial period is consistent with data from other tectonically stable coastlines (Muhs, 2002). For example, U-series ages of $\sim 120,000-130,000 \mathrm{yr}$ are reported for coral-bearing marine deposits $\sim 5 \mathrm{~m}$ above sea level on the tectonically stable islands of the Bahamas (Chen et al., 1991) and Bermuda (Muhs et al., 2002b). Much of south Florida stands only a few meters above sea level. Thus, the shoreline during the last interglacial period would have been considerably landward of where it is now and the exposed part of the Florida peninsula would have been greatly diminished in areal extent (Fig. 4). During this high stand of the sea, all of the Florida Keys would have been submerged.

\section{Florida Keys: A Sea-Level High Stand Late in the Last Interglacial Period}

Seaward of the lower Florida Keys (Fig. 4), there are outlier reef tracts called Sand Key and Carysfort reef that have been described in detail by Lidz et al. (1991, 1997). Ludwig et al. (1996) and later Toscano \& Lundberg (1999) reported TIMS U-series ages of corals from the crest of Sand Key reef, at depths of about 11-14 m, that range from about 80,000 to $84,000 \mathrm{yr}$. Similar ages were reported by Toscano \& Lundberg (1999) for Carysfort Reef, another outlier reef seaward of Key Largo (Figs 4 and 5). Thus, these reefs formed during MIS $5 \mathrm{a}$. The issue of how high sea level was at the time is difficult to resolve, because none of the $\sim 80,000$-yr-old corals from the crest of Sand Key reef is a shallow-water species. The main species from Sand Key, Montastrea annularis, has a depth range of -3 to $-80 \mathrm{~m}$. Toscano \& Lundberg (1999) did succeed in recovering Acropora palmata, a strictly shallowwater species, from Carysfort reef at water depths of $-15.2 \mathrm{~m}$ 
( $\sim 85,000 \mathrm{yr})$ and $-15.5 \mathrm{~m}(\sim 92,000 \mathrm{yr})$. Because Acropora palmata grows within $5 \mathrm{~m}$ of the sea surface (Lighty et al., 1982), sea level could have been no lower than $\sim 20$ m below present at these times. These data provide some measure of the possible amount of sea-level lowering during MIS 5b and the start of MIS 5a (Fig. 1).

\section{Sea Level During the Last Glacial Period and the Holocene: Caribbean Islands and Florida}

One of the best records of last-glacial sea-level lowering and postglacial sea-level rise comes from a series of submerged reefs off Barbados, studied by Fairbanks (1989) and Bard et al. (1990). Paleo-sea levels for such reefs can be estimated using the shallow-water, reef-crest coral Acropora palmata because: (1) A. palmata almost always occurs in waters shallower than $\sim 5$ m (Lighty et al., 1982); (2) its branching form allows easy recognition of whether or not it is still in growth position; (3) it grows rapidly enough that it can keep pace with a rising sea level (Buddemeier \& Smith, 1988); and (4) it can be dated by both U-series and radiocarbon methods. The submerged Barbados reefs indicate that during the last-glacial maximum, sea level was $\sim 120 \mathrm{~m}$ lower than present, close to the estimate made by Shepard (1973), who used a worldwide average of the depth of the continental shelf-continental slope boundary. The sea-level curves given by Fairbanks (1989) and Bard et al. (1990) show two periods of relatively rapid sea-level rise due to rapid ice melting. The dual dating using U-series and radiocarbon has allowed calibration of radiocarbon ages older than what was possible using tree-ring data. Modeling efforts have shown that the Barbados submerged reefs may be one of the best records of eustatic sea-level rise since the last glacial maximum (Milne et al., 2002; Peltier, 2002). Based on the estimate of $\sim 120$-m sea-level lowering during the last glacial period, the paleogeography of Florida would have been drastically different from present, with a Gulf Coast shoreline considerably farther to the west (Fig. 4).

Studies of Acropora palmata-dominated reefs off the mainland and islands of the U.S. have allowed an extension of the Barbados sea-level curve into the mid- and late Holocene (Fig. 6). Submerged reefs have been identified off the Florida mainland, the Florida Keys, Puerto Rico, and St. Croix (Lidz et al., 1991, 1997; Lighty et al., 1978, 1982; Ludwig et al., 1996; Toscano \& Lundberg, 1998). Although other Holocene sea-level curves have been made (Bloom, 1983b; Kidson, 1982), the advantage of the Florida and Puerto Rico-St. Croix records is that, as with Barbados, they utilize Acropora palmata-dominated reefs. For the reasons given above, this coral is probably more robust, both for dating and as a sea-level indicator, than other records that utilize shell beds or terrestrial peat/marine sediment contacts. Macintyre (1988) pointed out that the Florida reef record is limited to the early Holocene. About 7000-8000 cal yr B.P., flooding of the Florida continental shelf would have brought about soil erosion and increased turbidity that may have terminated the growth of Acropora palmata-dominated reefs. However, the early Holocene Florida record overlaps the Barbados record and is in broad agreement with it. Younger submerged reefs have been studied off Puerto Rico and St. Croix (Lighty et al., 1982; Macintyre, 1988; Macintyre et al., 1983). The combined records of the Florida

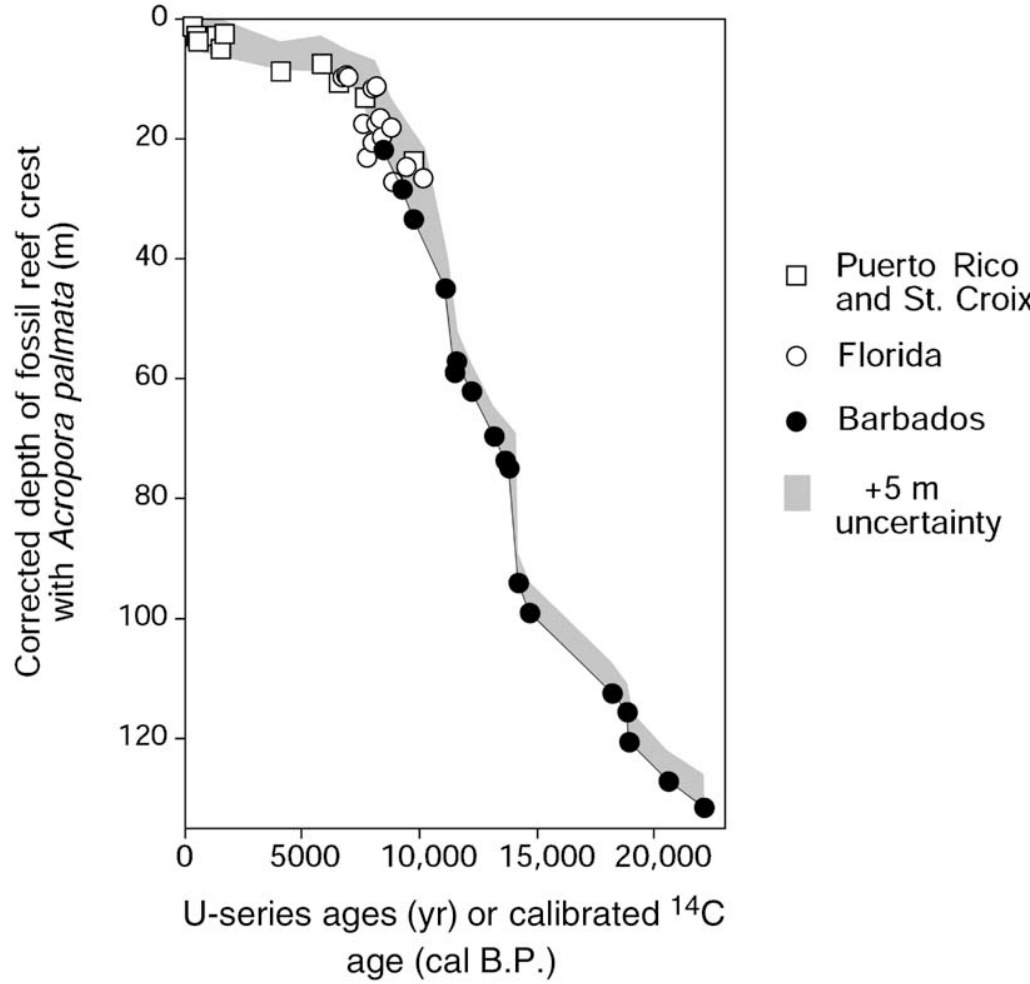

Fig. 6. Graph showing sea-level rise from the lastglacial maximum to the present based on elevations of dated specimens of the shallow-water coral Acropora palmata from submerged reefs off Barbados (Fairbanks, 1989; Bard et al., 1990), Florida (Ludwig et al., 1996; Toscano \& Lundberg, 1998), and Puerto Rico-St. Croix (Lighty et al., 1978, 1982; Macintyre et al., 1983). Barbados points are based on $U$-series ages and are corrected for tectonic uplift (Fairbanks, 1989). Some Florida reefs are U-series dated; others and all Puerto RicoSt. Croix reefs are dated by radiocarbon and have been converted to calendar years using Stuiver et al. (1998). 
and Puerto Rico-St. Croix reefs allow extension of the Barbados record into the Holocene and up to present sea level (Fig. 6).

\section{Hawaiian Islands}

The Hawaiian Islands contain some of the best records of Quaternary sea-level fluctuations, both onshore and offshore. As with the Florida Keys, Hawaiian marine deposits have the advantage of recording paleo-sea levels accurately with in situ reefs that contain corals suitable for U-series dating. Stearns (1978), who studied marine deposits on the Hawaiian Islands for more than 40 years, provided a summary of the geologic record of Quaternary sea-level fluctuations. Since the time of that summary, however, new studies have provided additional insight into sea-level history.

Unlike Florida, Oahu has experienced slow uplift over much of the mid-to-late Quaternary, an idea proposed originally by Moore (1970). Volcanic loading on the "big island" of Hawaii results in a compensatory, upward lithospheric flexure on distant islands such as Oahu, Molokai, and Lanai. For example, deposits of the last-interglacial Waimanalo Limestone on Oahu are, in places, several meters higher than the estimated $+6 \mathrm{~m}$ position for this high sea stand (Muhs \& Szabo, 1994). Veeh (1966), in a now-classic study, assumed that mid-plate Pacific islands such as Oahu would be ideal "dipsticks" for estimating paleo-sea levels. However, it is now apparent that marine deposits on the Hawaiian Islands, like the Cook Islands (Woodroffe et al., 1991), need to be considered in light of at least modest Quaternary uplift.

\section{Pre-last Interglacial High Stands of Sea}

When Stearns (1978) summarized his career-long views on the sea-level history of the Hawaiian Islands, he was correct that records of older, pre-last-interglacial high stands of sea exist on the islands. On Oahu, southeast of Kaena Point (Fig. 7), a marine deposit $\sim 30 \mathrm{~m}$ above sea level was designated as the "Kaena" shoreline by Stearns (1978). Muhs \& Szabo (1994) observed these and other $+30 \mathrm{~m}$ Kaena high stand deposits on Oahu and confirmed their general elevations. The sedimentology of these deposits and their limited, but similar elevations at a minimum of three localities on Oahu suggest that they are not deposits left by a tsunami from a submarine landslide of the sort that has been hypothesized for Lanai and other islands by Moore \& Moore $(1984,1988)$. Szabo \& others (1994), using TIMS methods, dated a coral from the $\sim 30$-m-high deposit at Kaena Point and reported a ${ }^{230} \mathrm{Th} /{ }^{238} \mathrm{U}$ age of $532,000(+130,000 /-70,000) \mathrm{yr}$, with an initial ${ }^{234} \mathrm{U} /{ }^{238} \mathrm{U}$ value that would permit interpretation of a closed-system history. Hearty (2002) reported a TIMS U-series age on a coral from the same deposit of 529,000 $(+47,000 /-35,000)$ yr (analyzed by R.L. Edwards \& H. Cheng, University of Minnesota), in excellent agreement with the age reported by Szabo et al. (1994). Hearty (2002) chose to reject both ages on the basis of whole-rock amino acid data, calibrated to $\sim 120,000$-yr-old deposits on Oahu (also dated by U-series methods). Nevertheless, it seems simpler to interpret the two U-series ages as representing deposits of a high sea stand around 500,000-600,000 yr, elevated to $\sim 30 \mathrm{~m}$ as a result of a modest $\left(0.05-0.06 \mathrm{~m} / 10^{3} \mathrm{yr}\right)$ long-term uplift rate. Such an uplift rate is consistent with that calculated for the $\sim 120,000 \mathrm{yr}$ deposits on Oahu (Muhs \& Szabo, 1994).

Two recent studies have documented that deposits representing at least some part or parts of the penultimate interglacial complex (MIS 7) are found on the Hawaiian Islands. On the leeward (west) coast of Oahu, a nearshore terrace has been identified that slopes down to $\sim 20 \mathrm{~m}$ depth. Corals recovered from cores taken at water depths of $\sim 10 \mathrm{~m}$ on this terrace date to about $220,000-240,000$ yr (Sherman et al., 1999). Because the coral being dated, Porites lobata, lives at depths ranging from the intertidal zone down to $-60 \mathrm{~m}$, the depth data imply that sea level during some part of the penultimate interglacial complex must have been within $10 \mathrm{~m}$ of the present level and could have been higher. On the island of Lanai, Rubin et al. (2000) reported U-series ages of emergent coral clasts found in what appear to be California-style marine-terrace deposits. One of two age clusters $(\sim 196,000$ to $\sim 230,000 \mathrm{yr})$ dates to the penultimate interglacial period. However, Lanai, like Oahu, is probably undergoing slow uplift. Thus, the Hawaiian Islands have a record of the penultimate interglacial period, but precise timing and sea level position are not yet understood.

\section{The Waimanalo Limestone and the Last Interglacial Period}

The island of Oahu has one of the richest records of the last interglacial period in the marine deposits known as the Waimanalo Limestone (Fig. 7). This formation consists of a lower reef facies, with growth-position corals, overlain by a sand and gravel facies that contains coral clasts. Veeh (1966) was the first investigator to show that corals from this reef limestone dated to the peak of the last interglacial period. $\mathrm{Ku}$ et al. (1974) conducted an extensive study of corals from the Waimanalo Limestone and used both ${ }^{230} \mathrm{Th} /{ }^{234} \mathrm{U}$ and ${ }^{231} \mathrm{~Pa} /{ }^{235} \mathrm{U}$ dating methods. Concordance between the two methods in this study is excellent and shows that the last interglacial high sea stand on Oahu could have begun as early as $\sim 137,000 \mathrm{yr}$ ago and lasted until $\sim 112,000 \mathrm{yr}$ ago. A later study by Muhs \& Szabo (1994), also using alpha spectrometry, shows a range of ages from $\sim 138,000$ to $\sim 120,000$ yr. Szabo et al. (1994) and Muhs et al. (2002a) analyzed Oahu corals by TIMS with improved uncertainties (usually $1000 \mathrm{yr}$ ) and reported a range of ages between 134,000 and 113,000 yr, with most between 125,000 and 115,000 yr. Thus, the Waimanalo Limestone of Oahu has consistently shown evidence of a long last-interglacial period (Fig. 8).

A long last-interglacial period, with sea level at or above present for 10,000 to $20,000 \mathrm{yr}$, does not agree with the 

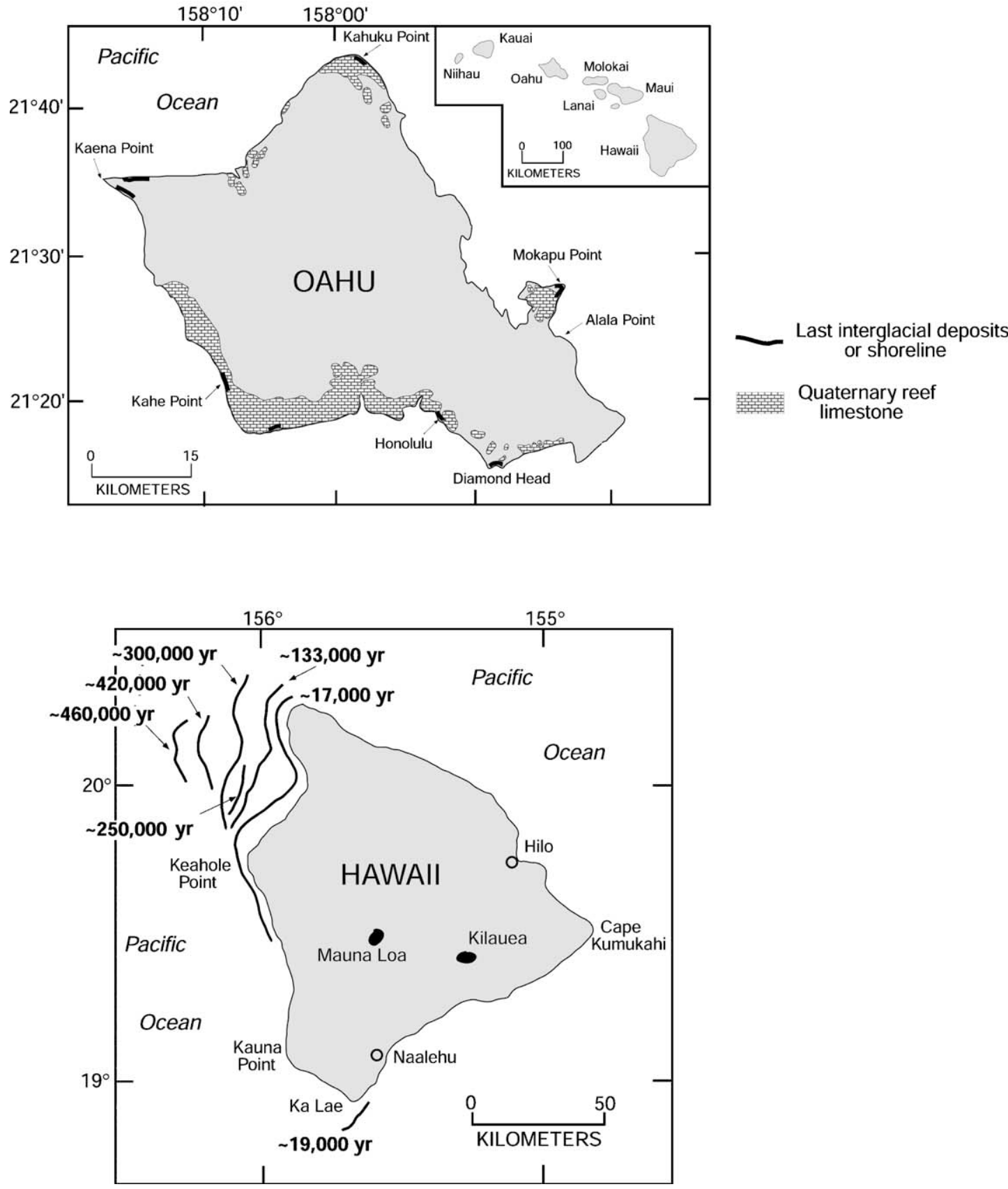

Fig. 7. Upper: map showing distribution of Quaternary limestone deposits (patterned areas) on the island of Oahu, Hawaii (from Stearns, 1974) and approximate locations of the last-interglacial Waimanalo shoreline (bold lines), based on U-series ages in Ku et al. (1971), Sherman et al. (1993), Szabo et al. (1994), Muhs \& Szabo (1994) and Muhs et al. (2002a). Lower: map of the island of Hawaii, showing submerged coral reef crests and their U-series ages (data from Ludwig et al., 1991).

SPECMAP estimates (Martinson et al., 1987) of the duration of this low-ice-volume period (Muhs, 2000). However, a long last interglacial period is in agreement with the Devils Hole, Nevada, oxygen isotope record, also dated by U-series methods (Winograd et al., 1997). Furthermore, the early start of the last interglacial high sea stand, as recorded on Oahu, is in agreement with other recent data (Gallup et al., 2002; Henderson \& Slowey, 2000) that sug- gest this warm period preceded the peak of summer insolation in the Northern Hemisphere (Fig. 8). The distribution of coral ages and stratigraphy given in $\mathrm{Ku}$ et al. (1974), Szabo et al. (1994), Muhs \& Szabo (1994) and Muhs et al. (2002a) also do not require or support the concept of a two-phase high stand at the peak of the last interglacial period, as proposed by Stearns (1978) and Sherman et al. (1993). 
Fig. 8. Records of the duration of the last interglacial period illustrated by range in ages of corals from the Waimanalo Formation of Oahu, Hawaii and the Pacific Coast of North America. Shown for comparison are curves of July insolation at $65 \mathrm{~N}$ (from Berger \& Loutre, 1991) and the SPECMAP record of oxygen isotopes in deep-sea cores (Martinson et al., 1987). Oahu data from Szabo et al.(1994) and Muhs et al.(2002a); San Clemente Island and Punta Banda data from Muhs et al. (2002b).

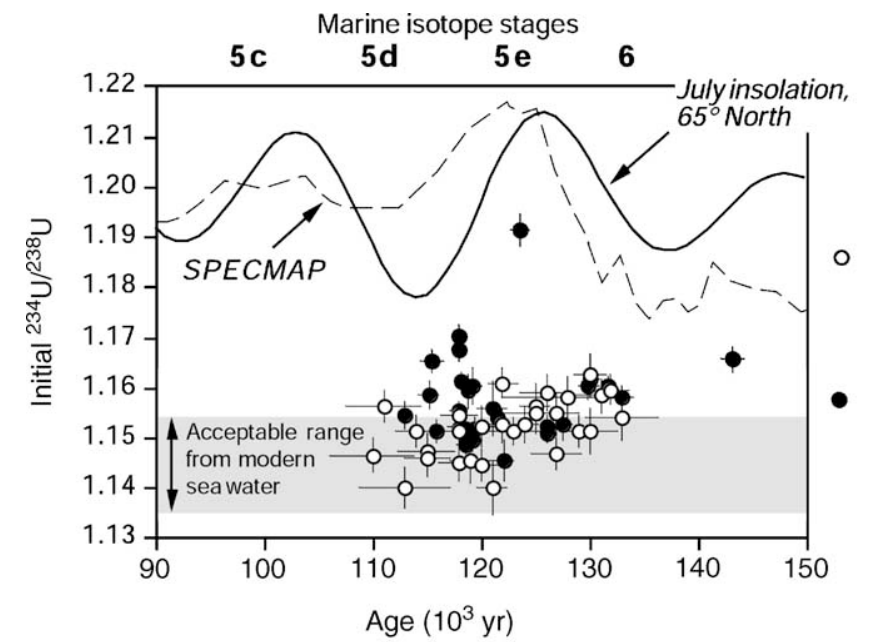

Oahu, Hawail

(Szabo et al., 1994)

Oahu, Hawaii

(Muhs et al. 2002a)

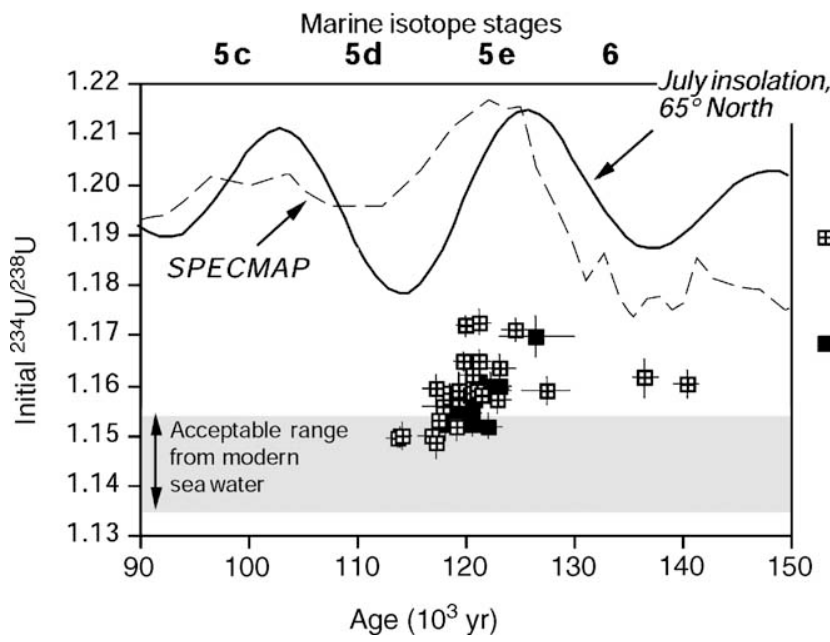

San Clemente Island, California

Punta Banda Baja California Mexico

The $\sim 120,000$-yr-old deposits on Oahu have fossil mollusks that provide important information on last-interglacial marine paleotemperatures. Two key fossil localities studied by Kosuge (1969) and dated by Szabo et al. (1994) and Muhs et al. (2002a) show that numerous extralimital Indo-Pacific mollusks are present in Waimanalo Limestone deposits. These taxa indicate warmer-than-present waters off Oahu during the peak of the last interglacial period.

\section{Origin of High-Elevation Marine Deposits on Lanai}

Fossiliferous marine deposits on the island of Lanai, at elevations of up to $365 \mathrm{~m}$, were interpreted by Stearns (1938) as representing a eustatic high stand of sea, a concept that he retained 40 years later (Stearns, 1978). However, a eustatic high stand of sea at this elevation is unlikely because there is not enough global ice on the continents for such a sea-level rise, a fact recognized by Stearns (1978, p. 13) himself. As mapped by Moore \& Moore (1988), most fossiliferous marine deposits on Lanai occur at elevations of $\sim 100 \mathrm{~m}$ or less, although some occur as high as $\sim 155 \mathrm{~m}$. Moore \& Moore
$(1984,1988)$ proposed that these deposits, as well as marine deposits at high elevations on Molokai and Maui, were deposited by a tsunami generated by a submarine landslide on an offshore scarp. U-series analyses of corals in the deposit on Lanai at elevations of 115-155 m gave ages of 101,000 to $134,000 \mathrm{yr}$, suggesting deposition at some time during the last interglaciation. Rubin et al. (2000) challenged the tsunami hypothesis. Corals in the gravels they studied date both to the last interglacial period $(\sim 130,000$ to $\sim 136,000 \mathrm{yr})$ and the penultimate interglacial period $(\sim 196,000$ to $\sim 230,000 \mathrm{yr})$. These workers proposed that the marine sediments were deposited and reworked by a combination of marine, fluvial and mass-movement processes, combined with slow uplift, as on Oahu.

\section{Sea-Level Low Stands Recorded on Hawaii}

Rapidly subsiding coastlines can have important records of sea-level low stands. The island of Hawaii, situated on an active hot spot, is subsiding due to ongoing volcanic loading (Moore \& Fornari, 1984). As a result, submerged coral 
reefs occur at depths of $150 \mathrm{~m}$ to more than $1300 \mathrm{~m}$ (Fig. 7). $\mathrm{U}$-series dating shows that the $-150 \mathrm{~m}$ reef dates to the last deglacial period, about 14,000-16,000 yr ago (Moore et al., 1990). Because sea level was no lower than about $-120 \mathrm{~m}$ during the last glacial period (Fairbanks, 1989), the reef crest at $-150 \mathrm{~m}$ demonstrates a subsidence rate of at least $2 \mathrm{~m} / 10^{3} \mathrm{yr}$. U-series ages of older submerged reefs show an average subsidence rate of about $2.6 \mathrm{~m} / 10^{3} \mathrm{yr}$ for at least the past $475,000 \mathrm{yr}$ (Ludwig et al., 1991). These studies demonstrate that the reefs grew in shallow water but were drowned by rising sea level at the close of successive glacial periods. Subsidence lowered each just-drowned reef, ultimately to form a submerged, stairstep-like sequence of reefs, analogous to emergent, uplifted reefs.

\section{Holocene Sea-Level History on the Hawaiian Islands}

The Hawaiian Islands have been used to test glacio-hydroisostatic models of sea-level history. Higher-than-present relative sea levels in the Holocene, followed by sea-level fall, are predicted for many low-latitude Pacific islands based on glacio-hydro-isostatic models (Clark et al., 1978; Mitrovica \& Peltier, 1991; Nakata \& Lambeck, 1989; Walcott, 1972). Stearns (1978) reported that there was a record of a higherthan-present Holocene sea-level stand on several of the Hawaiian Islands, based on radiocarbon ages of emergent marine deposits. This proposal was challenged by $\mathrm{Ku}$ et al . (1974), Easton \& Olson (1976), and Bryan \& Stephens (1993) who maintained that there had not been a higher-than-present sea level on the Hawaiian Islands since the last interglacial period, $\sim 120,000 \mathrm{yr}$ ago. Detailed stratigraphic studies with good age control on the islands of Oahu and Kauai show that relative sea level was indeed higher than present during the mid-to-late Holocene (Calhoun \& Fletcher, 1996; Fletcher \& Jones, 1996; Grossman \& Fletcher, 1998). This finding is consistent with data from many other tropical Pacific islands (Grossman et al., 1998) and indicates that Holocene sea-level histories will differ from region to region (Bloom, 1983b).

\section{Pacific Coast}

\section{Introduction: The Nature of the Pacific Coast Record}

Quaternary sea-level fluctuations have left a record on the coasts of California and Oregon in the form of emergent marine terraces. Spectacular flights of multiple marine terraces, forming a stairstep-like landscape, are found in California at Santa Cruz, the Palos Verdes Hills, San Clemente Island, and San Nicolas Island, and in southern Oregon near Coquille Point (Figs 3 and 9). Marine terraces, unlike constructional reef terraces of the tropics, are erosional landforms, although a veneer of marine sediment, sometimes fossiliferous, is generally present (Fig. 2). This is important for understanding the timing of sea-level stands recorded by marine terraces, because erosional landforms need not form at the same time as constructional landforms during a given sea-level high stand. On a tropical, constructional-reef coast, coral growth may keep pace with a rising sea and record the early part, as well as the peak, of a high sea stand. In contrast, on an erosional coast, the early part of a sea-level high stand may be characterized by platform cutting; fossils left behind on the platform may date to the peak of the sea-level stand or even the early part of regression (Bradley \& Griggs, 1976).

One problem that had long puzzled early researchers in California was why marine terraces occurred at different elevations in different places, if they were all due to the same sea-level high stands. Alexander (1953) provided the explanation when he showed that marine and stream terraces in central California formed as a result of sea-level high stands superimposed on a tectonically uplifting coast. Thus, flights of marine terraces from place to place could indeed have formed during the same succession of interglacial high sea stands, but differ in their elevations because of differing local uplift rates. Research conducted in the past three decades has confirmed Alexander's (1953) general model (Anderson \& Menking, 1994; Grant et al., 1999; Hanson et al., 1992; Kelsey, 1990; Kelsey \& Bockheim, 1994; Kelsey et al., 1996; Kern \& Rockwell, 1992; Lajoie et al., 1979, 1991; Merritts \& Bull, 1989; Muhs et al., 1990, 1992a, 2002b; Rockwell et al., 1989, 1992; Wehmiller \& Belknap, 1978; Wehmiller et al., 1977).

\section{Sea-Level History Before the Last Interglacial Period}

Several localities along the Pacific Coast, such as the Palos Verdes Hills, San Nicolas Island, and San Clemente Island (Figs 3 and 9), have fossil-bearing, high-elevation terraces. Few of them, however, have been studied for dating purposes. Some of these terraces can be correlated from locality to locality using amino acid and Sr-isotope methods (Kennedy et al., 1982; Ludwig et al., 1992a; Wehmiller et al., 1977), but numerical ages are lacking.

Vedder \& Norris (1963) reported corals in deposits of many of the older terraces on San Nicolas Island. We collected unaltered (100\% aragonite) specimens of the solitary coral Balanophyllia elegans from the 10th terrace (inner edge elevation of $\sim 240 \mathrm{~m}$ ) on this island (LACMIP loc. 10626; Fig. 9). These results (Table 1) are presented here in order to demonstrate the potential for dating older high sea stands on the Pacific Coast. Laboratory methods for these analyses follow Ludwig et al. (1992b); half-lives used for age calculations are those of Cheng et al. (2000). Four of eight corals analyzed show evidence of closed-system conditions (initial ${ }^{234} \mathrm{U} /{ }^{238} \mathrm{U}$ values close to modern seawater, $\mathrm{U}$ contents similar to modern corals, and no evidence of inherited ${ }^{230} \mathrm{Th}$ ). Because the corals are near the upper limit for TIMS U-series dating, uncertainties are relatively high, but the individual ages $(451,000 \pm 29,000 ; \quad 596,000 \pm 96,000 ; \quad 498,000 \pm 35,000 ;$ and 526,000 $\pm 41,000 \mathrm{yr}$ ) suggest a marine terrace age of perhaps $\sim 500,000 \mathrm{yr}$. This age, along with ages of the lower two terraces on San Nicolas Island (Muhs et al., 1994, 2002c), permit a possible correlation of intermediate terraces with other interglacial intervals found in the oxygen isotope record (Fig. 10). If these correlations are correct, San Nicolas Island 


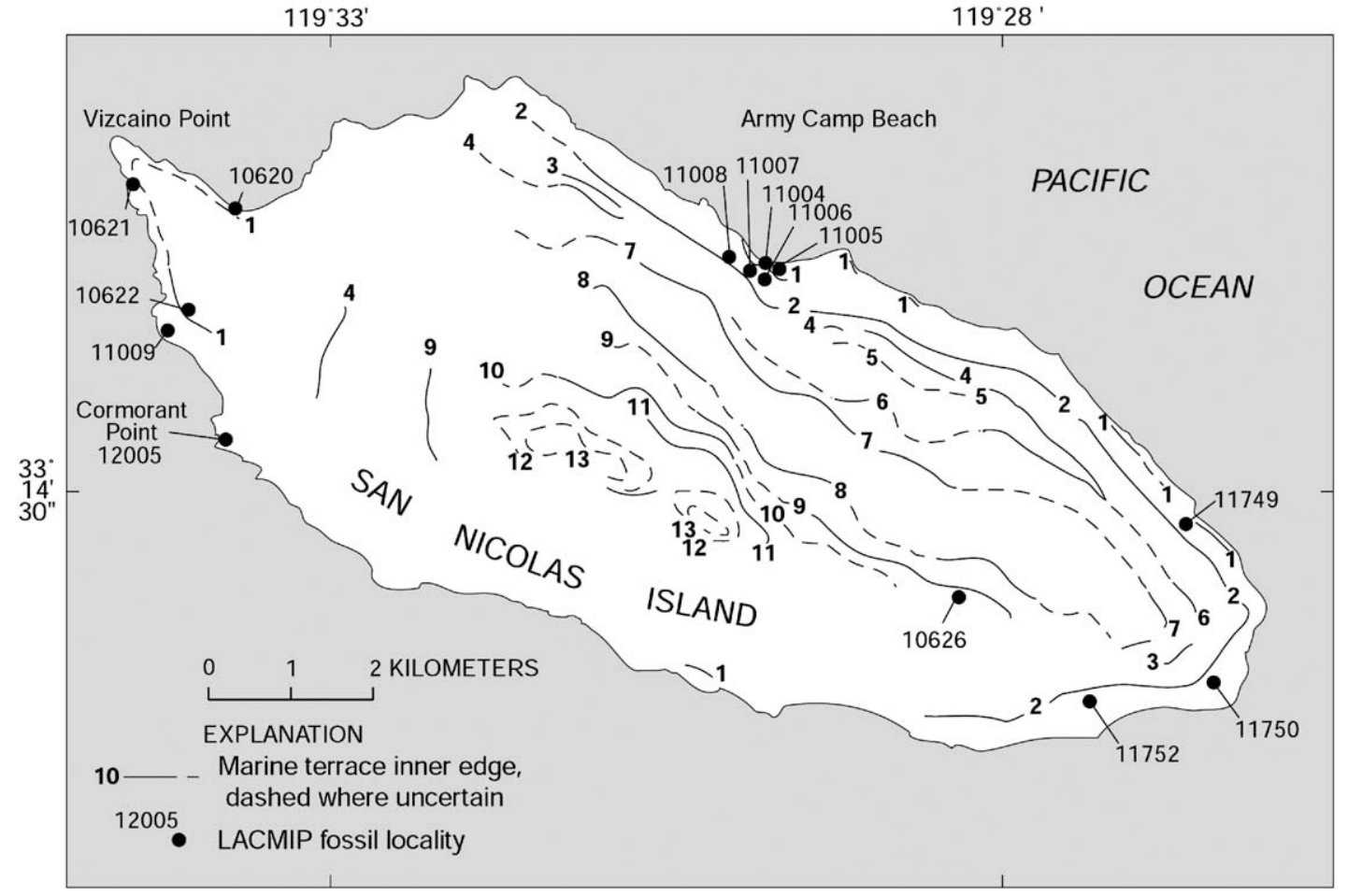

Fig. 9. Map of San Nicolas Island, California, showing inner edges of marine terraces and fossil localities (LACMIP = Los Angeles County Museum, Invertebrate Paleontology locality). Terrace inner edge data from Vedder \& Norris (1963), except for the 1st terrace, which was mapped mostly by Muhs et al.(1994). U-series ages of fossil corals from the 10th terrace are from LACMIP loc. 10626 (see Table 1).

has much of the record of interglacial high sea stands of the past half-million years. Other fossil-bearing, high-elevation terraces elsewhere on the Pacific Coast (e.g. the Palos Verdes Hills) may have similar sea-level records that could be dated.

Aminostratigraphy and U-Series Ages of the Last Interglacial Period on the Pacific Coast

A major effort was made in the 1970s to link marine terraces all along the Pacific Coast with global high sea stands. This was accomplished by showing that terraces could be correlated laterally using amino acid isochrons that capitalized on the regional temperature gradient of this north-south-trending coastline (Kennedy et al., 1982; Lajoie et al., 1979; Wehmiller \& Belknap, 1978; Wehmiller et al., 1977). Early U-series dating of solitary corals recovered from low terraces at Cayucos, San Nicolas Island, and Point Loma (near San Diego) showed that the California coast has terraces that date to the last interglacial period (Ku \& Kern, 1974; Valentine \& Veeh, 1969; Veeh \& Valentine, 1967). The age of these terraces, around $120,000 \mathrm{yr}$, is similar to what was being reported during the

Table 1. $U$ and Th concentrations, isotopic activity ratios and ages of corals (Balanophyllia elegans) from LACMIP loc. 10626, 10th marine terrace, San Nicolas Island, $C A^{\mathrm{a}}$

\begin{tabular}{|c|c|c|c|c|c|c|c|c|c|c|c|}
\hline Sample & $\begin{array}{c}\mathrm{U} \\
(\mathrm{ppm})\end{array}$ & $\begin{array}{c}\text { Th } \\
(\mathrm{ppm})\end{array}$ & $\begin{array}{c}{ }^{234} \mathrm{U} /{ }^{238} \mathrm{U} \\
\mathrm{AR}\end{array}$ & \pm & $\begin{array}{c}{ }^{230} \mathrm{Th} /{ }^{238} \mathrm{U} \\
\mathrm{AR}\end{array}$ & \pm & $\begin{array}{c}{ }^{230} \mathrm{Th} /{ }^{232} \mathrm{Th} \\
\mathrm{AR}\end{array}$ & $\begin{array}{c}{ }^{230} \mathrm{Th} /{ }^{238} \mathrm{U} \\
\text { Age }\left(10^{3} \mathrm{yr}\right)\end{array}$ & $\pm\left(10^{3} \mathrm{yr}\right)$ & $\begin{array}{c}{ }^{234} \mathrm{U} /{ }^{238} \mathrm{U} \\
\text { Init AR }\end{array}$ & \pm \\
\hline SNI-19-A & 3.23 & 0.0103 & 1.0452 & 0.0025 & 1.0499 & 0.0036 & 997 & 451 & 29 & 1.1619 & 0.0097 \\
\hline SNI-19-B & 3.60 & 0.0116 & 1.0263 & 0.0022 & 1.0372 & 0.0030 & 980 & 596 & 96 & 1.1417 & 0.0311 \\
\hline SNI-19-C & 3.22 & 0.0147 & 1.0389 & 0.0019 & 1.0476 & 0.0029 & 698 & 498 & 35 & 1.1588 & 0.0118 \\
\hline SNI-19-D & 3.07 & 0.0062 & 1.0429 & 0.0014 & 1.0634 & 0.0024 & 1603 & n.d. & n.d. & n.d. & n.d. \\
\hline SNI-10-A & 3.43 & 0.0135 & 1.0389 & 0.0018 & 1.0686 & 0.0027 & 825 & n.d. & n.d. & n.d. & n.d. \\
\hline SNI-10-B & 3.20 & 0.0063 & 1.0418 & 0.0019 & 1.0701 & 0.0026 & 1637 & n.d. & n.d. & n.d. & n.d. \\
\hline SNI-10-C & 2.78 & 0.0071 & 1.0341 & 0.0017 & 1.0395 & 0.0026 & 1228 & 526 & 41 & 1.1508 & 0.0139 \\
\hline SNI-10-D & 3.16 & 0.0097 & 1.0668 & 0.0019 & 1.0939 & 0.0035 & 1078 & 705 & 208 & 1.4899 & 0.2800 \\
\hline
\end{tabular}

a AR = activity ratio. Errors given are two-sigma. Ages calculated using half-lives given in Cheng et al. (2000). "n.d.," not determined. 


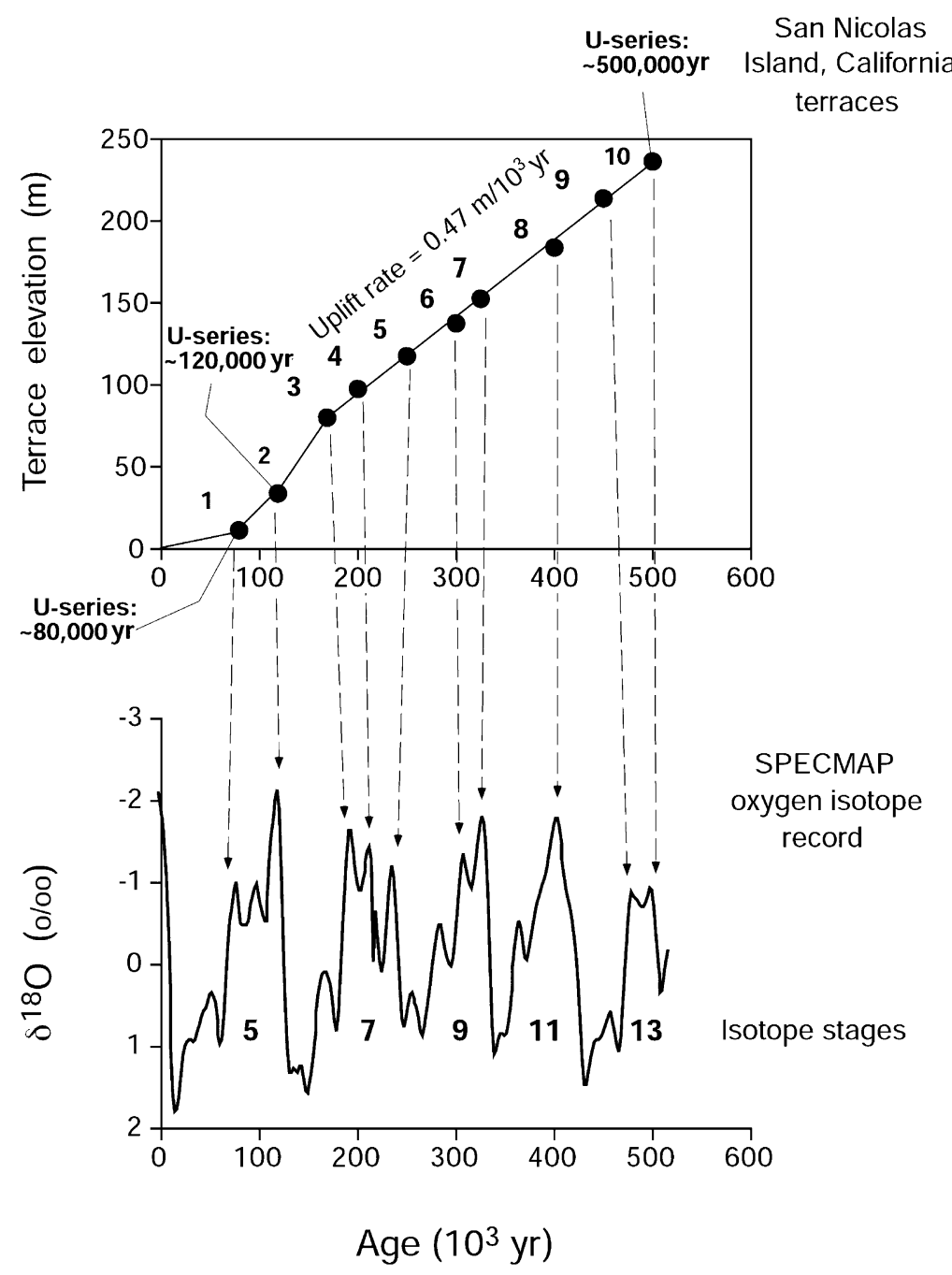

Fig. 10. Plot of terrace elevations as a function of terrace age, San Nicolas Island, California, and possible correlations with the deep-sea oxygen isotope record. Ages of the 1st, $2 n d$, and 10th terraces are based on U-series analyses of fossil corals; ages of other terraces are based on an assumed longterm uplift rate of $\sim 0.47 \mathrm{~m} / 1000 \mathrm{yr}$ from the age, elevation and an assumed near-present paleo-sea level for the 10th terrace. U-series data are from Muhs et al. (1994, 2002c) for the 1st and 2nd terraces and Table 1 of this paper for the 10th terrace. Terrace elevations are from Muhs et al. (1994) for the 1st and 2nd terraces and from Vedder \& Norris (1963) for all other terraces. Oxygen isotope data are from the SPECMAP oxygen isotope curve of Imbrie et al. (1984).

late 1960s for reef terraces on tropical coastlines (Broecker et al., 1968; Ku, 1968; Mesolella et al., 1969; Veeh, 1966; Veeh \& Chappell, 1970). The three coral-bearing localities in California provided numerical age control that allowed correlation of the $\sim 120,000$-yr-old high sea stand over hundreds of kilometers of the Pacific Coast (Fig. 11). Furthermore, lower amino acid ratios showed that one or more late, lastinterglacial $(\sim 80,000$ or $\sim 100,000 \mathrm{yr})$ and mid-Wisconsin ( $\sim 30,000-60,000 \mathrm{yr})$ high stands were likely present at many localities. Even lower amino acid ratios showed that Holocene terraces were present in areas with high uplift rates, near Ventura and Santa Barbara (Fig. 3), where the "big bend" in the San Andreas fault zone results in a compressional tectonic style. Later U-series dating of corals has confirmed the midWisconsin, $\sim 80,000$ and $\sim 120,000$ yr age estimates of many localities that were correlated by amino acid methods (Muhs et al., 1990, 1994, 2002b; Stein et al., 1991; Trecker et al., 1998). Radiocarbon dating has confirmed the Holocene terrace ages (Lajoie et al., 1979; Sarna-Wojcicki et al., 1987).

The aminostratigraphy for the Pacific Coast generated by Wehmiller, Kennedy and Lajoie resolved another problem in Quaternary sea-level history and paleoclimatology. Some low-elevation marine terrace localities in California were observed to have extralimital southern ("warm") species in their fossil faunas and others had only extralimital northern ("cool") species (Addicott, 1966; Valentine, 1958, 1961; Vedder \& Norris, 1963; Woodring et al., 1946). Still other localities had mixtures of extralimital southern and northern mollusks. Resolution of the apparent contradiction of low terraces with cool species and other low terraces with warm species came with a combination of U-series dating, aminostratigraphy, and detailed faunal analyses (Kennedy et al., 1982; Muhs et al., 2002b; Wehmiller et al., 1977). Those terrace localities with warm species, "neutral" species (i.e. those with faunas similar to those of today) or mixtures of warm and cool species date to the $\sim 120,000$-yr-old high sea stand (Fig. 11). Localities with slightly lower amino acid ratios, which correlate to the $\sim 80,000$-yr-old high sea stand, have faunas that contain some cool-water species but do not have warm-water species (Kennedy et al., 1982).

High-precision, TIMS U-series dating of marine terrace corals has been accomplished for a number of localities in 


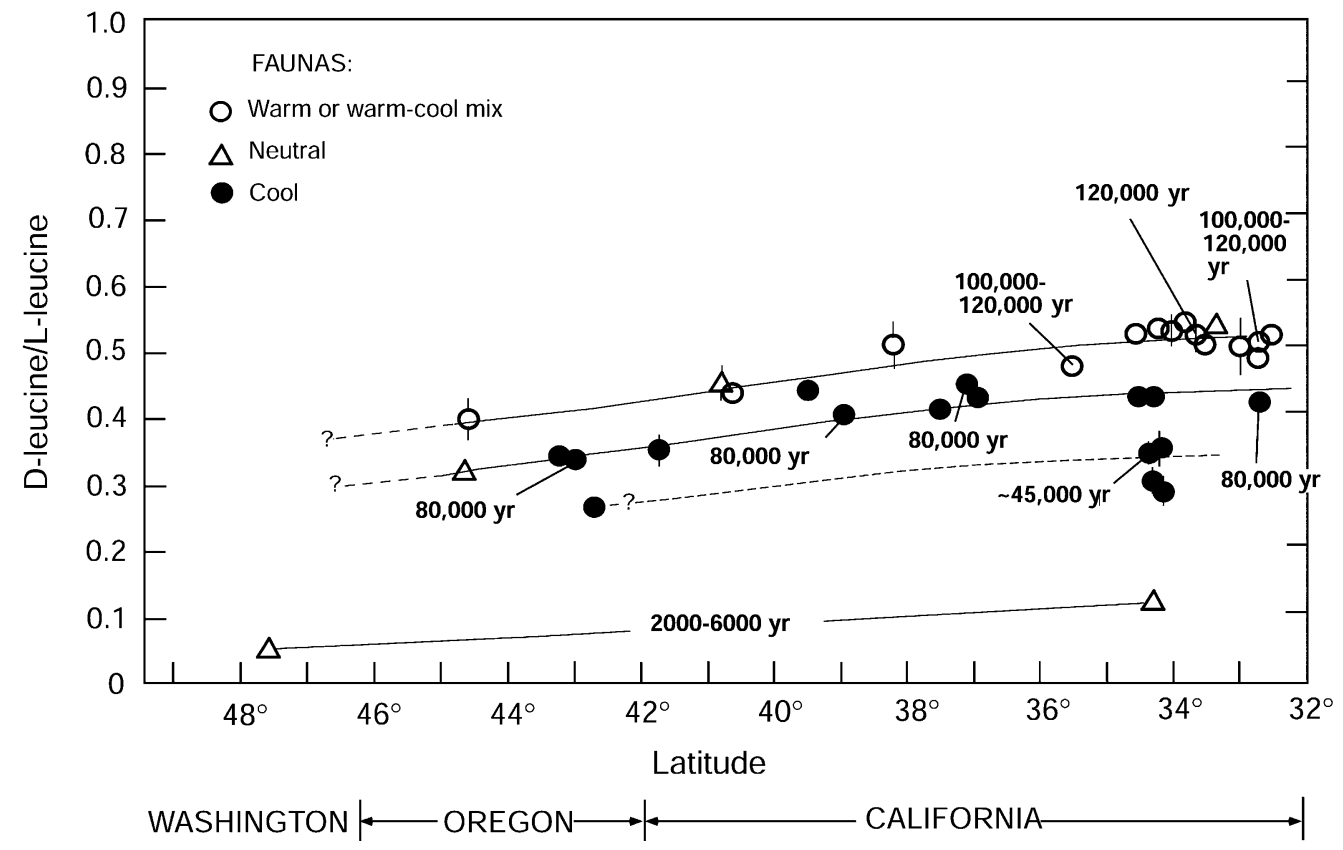

Fig. 11. Ratios of the amino acids D-leucine to L-leucine in the fossil bivalves Protothaca and Saxidomus from marine terrace deposits on the Pacific Coast of the United States, shown as a function of latitude (redrawn in modified form from Kennedy et al., 1982). Lines connect geographically proximal localities that are thought to be correlative based on similar, but northwarddecreasing amino acid ratios and similar faunal zoogeographic aspects. Also shown are U-series ages on Pleistocene corals from localities where they are present (data from Muhs et al., 1990, 1994, 2002a; Grant et al., 1999; Trecker et al., 1998), and radiocarbon ages on Holocene mollusks (Lajoie et al., 1979; Sarna-Wojcicki et al., 1987).

California and Baja California (Muhs et al., 2002b). Results show that the last interglacial high sea stand on the Pacific Coast lasted at least $9000 \mathrm{yr}$, from about 123,000 to $\sim 114,000$ yr ago (Fig. 8). In the Bahamas, Barbados, and Hawaii, the same high sea stand is recorded as early as $\sim 130,000 \mathrm{yr}$ (Chen et al., 1991; Gallup et al., 1994,2002; Muhs et al.,2002a). The difference in timing between the tropical island and Pacific Coast records supports a model proposed by Bradley \& Griggs (1976). In this model, the early period of a high sea stand on the Pacific Coast is represented by an interval of terrace platform cutting. At the same time, vigorous upward reef growth is occurring along coasts in the tropics. Fossil deposition on the Pacific Coast follows the period of platform cutting. Thus, on the Pacific Coast, most corals date to either the regressional phase of a high sea stand or just before it, whereas tropical corals date as far back as the period when sea level was still rising.

Recent studies show that the $\sim 80,000$-yr-old sea-level stand on the Pacific Coast may have been of similar duration to the $\sim 120,000$-yr-old high stand (Muhs et al., 2002c). New U-series ages of solitary corals from Coquille Point, Oregon and numerous localities in California (Point Arena, Point Año Nuevo, Point Santa Cruz, Palos Verdes Hills, and San Nicolas Island; Fig. 3) show that this high stand could have begun around 86,000-84,000 yr ago and lasted until $\sim 76,000$ yr ago, a duration of 8000-10,000 yr. This range of ages is similar to that of corals from the Southampton Formation of Bermuda (Muhs et al., 2002a) and corals from the U.S. Atlantic Coastal Plain (see below). Similar records from all three coasts (Pacific, Atlantic, and Bermuda) indicate that this was probably a sea-level stand of a longer duration than has been interpreted from the deep-sea oxygen isotope record (Martinson et al., 1987).

\section{Sea-Level Positions $\sim 100,000$ and $\sim 80,000$ yr Ago on the Pacific Coast}

Both $\sim 100,000$ and $\sim 120,000$-yr-old corals are found in terrace deposits at Cayucos and Point Loma, California (Muhs et al., 2002b; Stein et al., 1991). This finding provides evidence that the $\sim 100,000$-yr-old high stand likely reoccupied at least part of the $\sim 120,000$-yr-old terrace. Such a mechanism could explain the mixture of extralimital southern and northern species of mollusks found at both Cayucos and Point Loma. The northern species could date to the $\sim 100,000$-yr-old high sea stand whereas the southern species could date to the $\sim 120,000$-yr-old high sea stand (Muhs et al., 2002b). At Cayucos, the shoreline angle of the terrace is only about $7-8 \mathrm{~m}$ above sea level (Fig. 12), indicating that little or no uplift has occurred in the past $\sim 120,000$ yr. Thus, Muhs et al. (2002b) interpreted these data to indicate that the $\sim 100,000$-yr-old high sea stand must have been close to present. At Punta Banda, Baja 
CAYUCOS, CALIFORNIA:

$\longleftarrow$ SOUTH

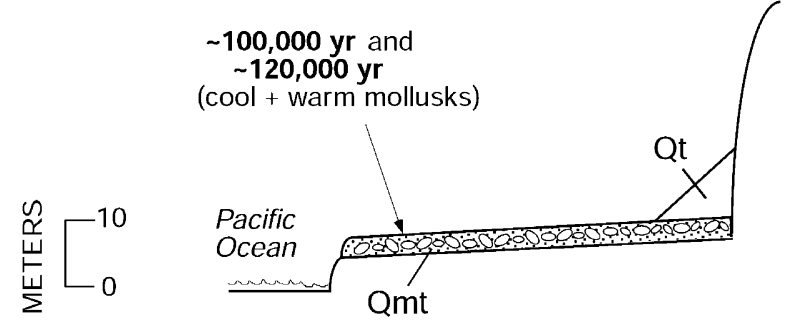

POINT LOMA, CALIFORNIA:
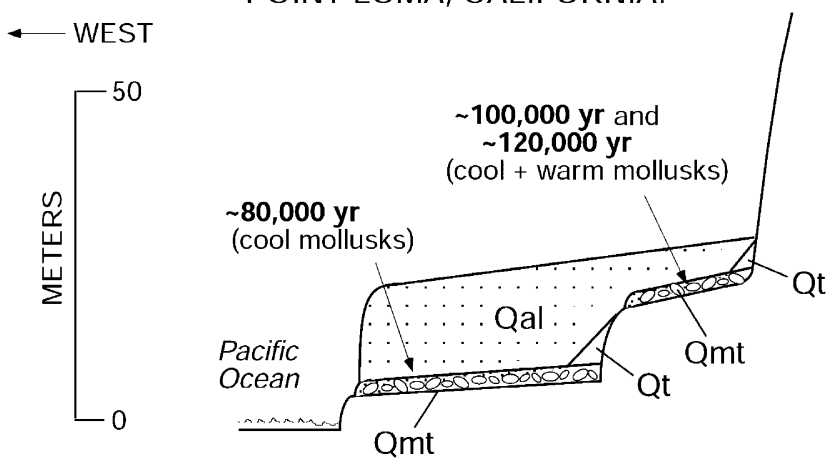

PUNTA BANDA, BAJA CALIFORNIA:
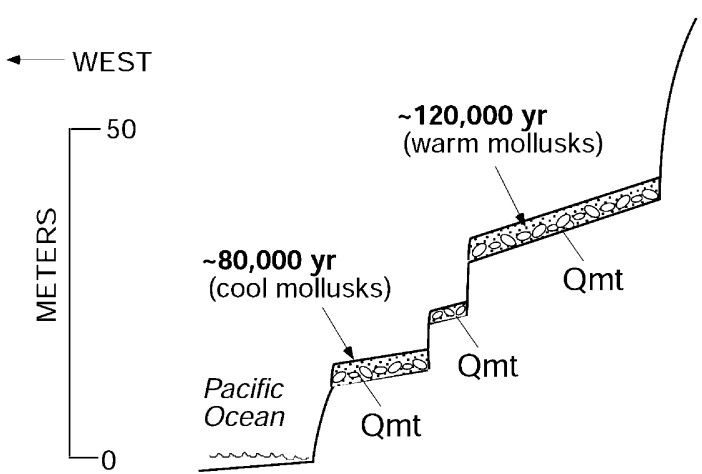

0

METERS

Fig. 12. Shore-normal profiles of low terraces at Cayucos and Point Loma, California and Punta Banda, Baja California, showing average U-series ages of individual corals and faunal thermal aspects. Abbreviations for deposits: Qal, alluvium; Qt, talus and other colluvial deposits; Qmt, marine terrace deposits. From data in Muhs et al.(2002b).

California, where the uplift rate is greater, terrace reoccupation did not take place, and there is no apparent mixing of southern and northern faunas (Fig. 12). A terrace, inferred to represent the $\sim 100,000$-yr-old high sea stand, is found between the dated 80,000 and $120,000 \mathrm{yr}$ terraces at Punta Banda.

Terraces dating to the $\sim 80,000$-yr-old high sea stand have now been reported for localities from southern Oregon to northern Baja California (Muhs et al., 1990, 1994, 2002b, c). At many of these localities, higher terraces are dated directly or indirectly to the $\sim 120,000$-yr-old high sea stand. The elevation of the $80,000 \mathrm{yr}$ terrace can be plotted against the uplift rate (calculated using the elevation of the $\sim 120,000 \mathrm{yr}$ terrace) for a number of localities that span a range of uplift rates. If the plot is linear, the slope of the regression equation fitted to the data yields the approximate age $(\sim 80,000 \mathrm{yr})$ and the Y-axis intercept yields the paleo-sea level. We performed these calculations for the Pacific Coast of North America, the Huon Peninsula of New Guinea, Barbados, and Hateruma Island in the Ryukyu island chain of Japan (Fig. 13). The Pacific Coast, Hateruma Island and New Guinea data suggest that sea level $\sim 80,000 \mathrm{yr}$ ago was within $6 \mathrm{~m}$ of present. A widely cited sea-level curve derived from the oxygen isotope record suggests a level position significantly lower than present, about $-25 \mathrm{~m}$, at $\sim 80,000 \mathrm{yr}$ ago (Shackleton, 1987). The difference in estimates of sea level position between the terrace record and the oxygen isotope record is equivalent, in icevolume terms, to approximately three Greenland ice sheets. A new sea-level curve derived from oxygen isotope data indicates that sea level could have been near present $\sim 80,000$ yr ago (Shackleton, 2000), which is in better agreement with the terrace-derived sea level estimate presented here. Nevertheless, this recent estimate is based on a single measurement and more data are needed (N.J. Shackleton, written comm. to D.R. Muhs, 2003).

\section{Alaska}

Emergent Quaternary marine terraces and their associated deposits and fossils have long been recognized in Alaska. One of the classic study areas has been the Nome coastal plain on the Seward Peninsula (Figs 1 and 14), where Hopkins et al. (1960) and Hopkins (1967) reported three wave-cut benches, overlain by fossiliferous sand and gravel that resemble "California-style" marine terraces (Fig. 2). Unlike California, however, the Nome coastal plain is mantled with glacial deposits left by ice that advanced from mountain ranges farther north on the Seward Peninsula (Kaufman, 1992). Emergent marine terraces are also found elsewhere on the Seward Peninsula and on the Arctic Coastal Plain of Alaska (Fig. 14).

\section{Mid-Pleistocene Sea-Level History}

As with other coastlines of the United States, mid-Pleistocene marine deposits have been found in Alaska. A marine deposit, representing what has been called the "Anvilian" marine transgression, occurs extensively along the Seward Peninsula and Arctic Ocean coast of Alaska. It occurs landward of "Pelukian" (last interglacial) marine deposits and is found 

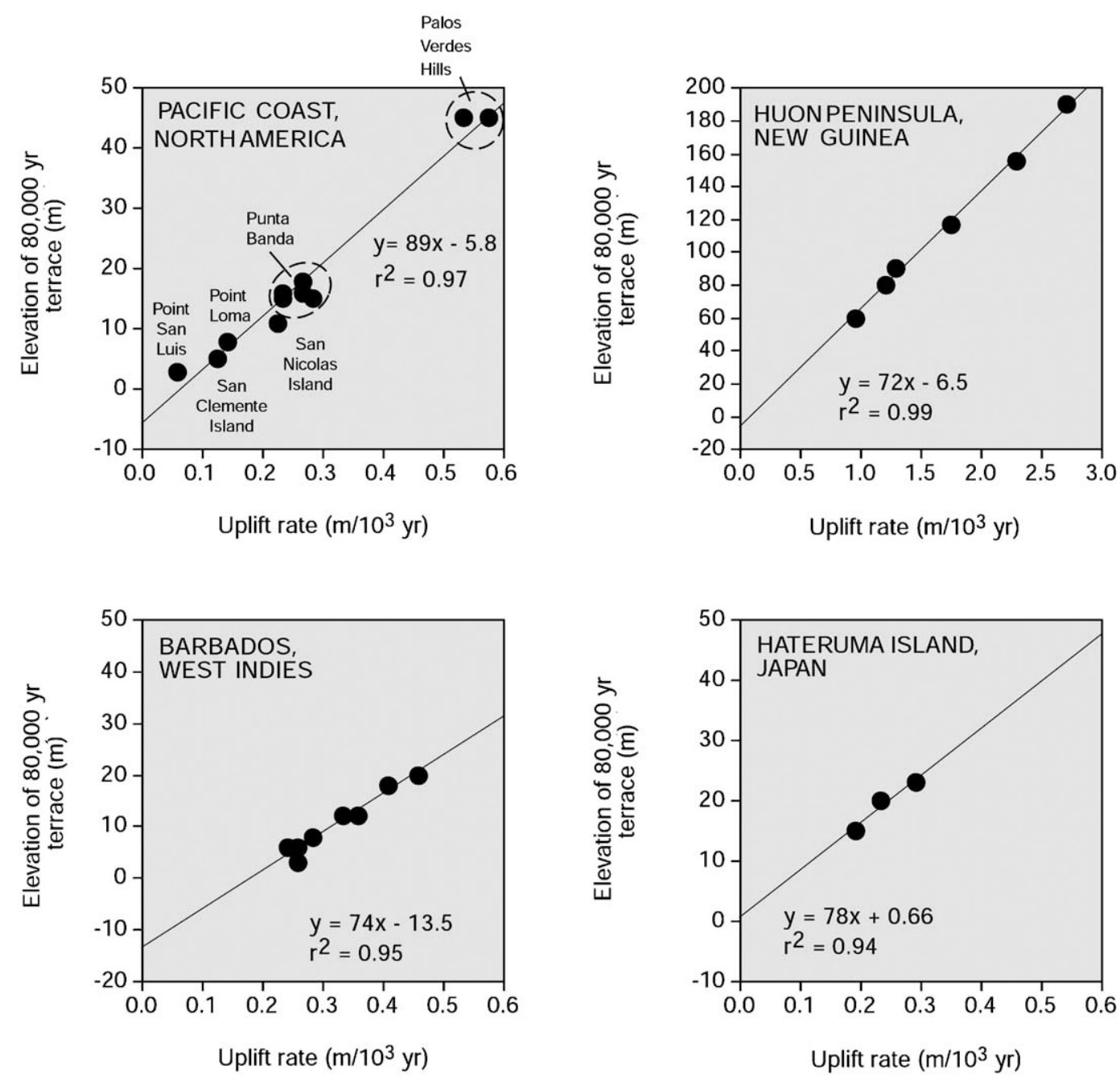

Fig. 13. Plots showing elevations of $\sim 80,000-y r$-old marine terraces or coral reefs as a function of uplift rate derived from $\sim 120,000$-yr-old marine terraces or reefs for four regions with differing uplift rates. Pacific Coast age and elevation data from Rockwell et al. (1989), Hanson et al.(1992), Kern \& Rockwell (1992), and Muhs et al.(1992a, 1994, 2002b, c); New Guinea data from Bloom et al. (1974); Barbados data from Broecker et al.(1968), Matthews (1973), and Taylor \& Mann (1991); Hateruma Island data from Ota \& Omura (1992).

at altitudes of up to $22 \mathrm{~m}$ (Kaufman et al., 1991). Amino acid ratios in mollusks presented by Kaufman \& BrighamGrette (1993) show that it is easily distinguishable from lastinterglacial Pelukian deposits, but it is younger than deposits thought to be of Pliocene age (Fig. 15). Kaufman et al. (1991) reported that basaltic lava overlies drift of the Nome River glaciation, which in turn overlies Anvilian marine deposits. An average of several ${ }^{40} \mathrm{Ar} /{ }^{39} \mathrm{Ar}$ analyses on the lava yields an age of $470,000 \pm 190,000 \mathrm{yr}$. Within the broad limits permitted by this age and using reasonable rates of epimerization of marine mollusks, Kaufman et al. (1991) proposed that the Anvilian marine transgression dates to $\sim 400,000 \mathrm{yr}$ ago and is correlative with a major interglacial period recorded by oxygen isotope stage 11 .

The high elevation (up to $\sim 22 \mathrm{~m}$ ) of the Anvilian marine deposits in a tectonically stable region suggests that sea level at that time could have been higher than present and even higher than during the last interglacial period. Recent studies from Bermuda, the Bahamas, the Cariaco Basin and the Netherlands Antilles, localities that are either tectonically stable or only slowly uplifting, suggest that sea level could have been $20-25 \mathrm{~m}$ above present during a $\sim 400,000$-yr-old sea-level stand (Hearty et al., 1999; Lundberg \& McFarlane, 2002; Poore \& Dowsett, 2001). A 20-25-m-high sea-level stand would require loss of all of the Greenland ice sheet, all of the West Antarctic ice sheet, and at least part of the East Antarctic ice sheet during a Quaternary interglacial period of exceptional warmth. Anvilian marine deposits contain no extralimital northern species of mollusks, but do contain at least six extralimital southern or southward-ranging species, including two that are now confined to lower latitudes in the Atlantic Ocean (Hopkins et al., 1960, 1974). Thus, the 


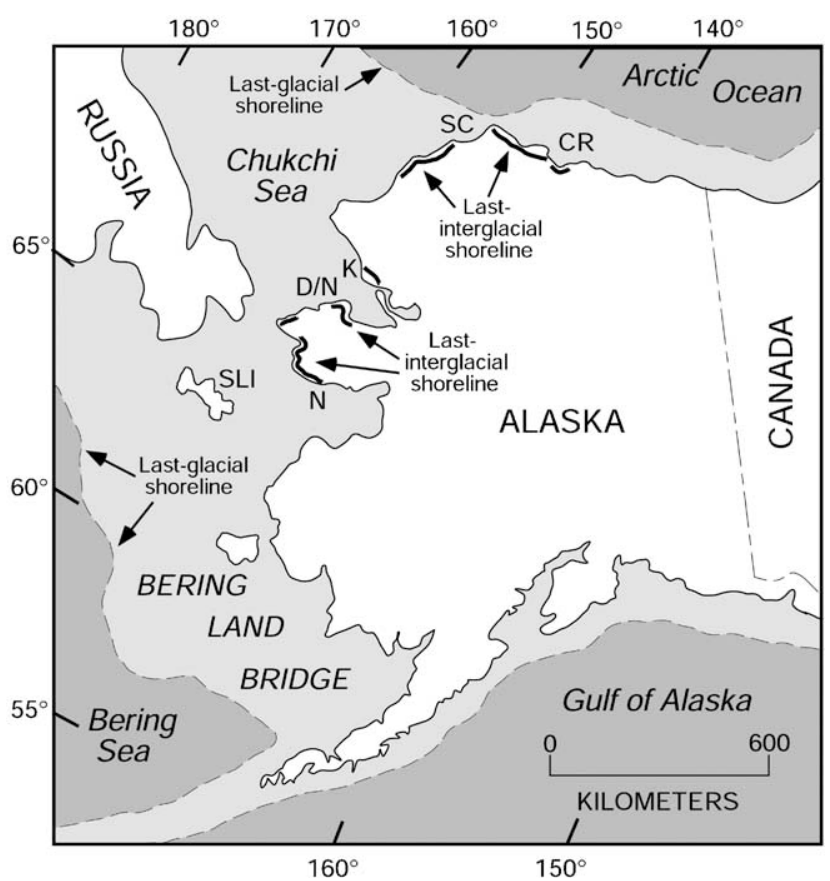

Fig. 14. Map of Alaska and adjacent regions showing last interglacial $(\sim 120,000 y r)$ and last-glacial $(\sim 20,000$ yr $)$ shorelines and localities referred to in text. Last interglacial shoreline is from Brigham-Grette \& Hopkins (1995); lastglacial shoreline is approximate and is based on an assumed $120 \mathrm{~m}$ sea-level-lowering during the last glacial period (Fairbanks, 1989). Abbreviations: CR, Colville River; SC, Skull Cliff; K, Krusenstern; D/N, Deering/Nugnugaluktuk; SLI, St. Lawrence Island; N, Nome.

Anvilian marine transgression may record a mid-Pleistocene high sea level that was significantly higher than present during a time of warmer climate.

\section{Last Interglacial Sea-Level History}

The lowest marine terrace deposit on the Nome coastal plain, also found on the Arctic Coastal Plain of Alaska (Fig. 14), formed during what has been called the Pelukian transgression. Hopkins (1973) correlated the Pelukian transgression with the peak of the last interglacial period, substage 5e of the oxygen isotope record. Analyses of Pelukian marine mollusks have yielded non-finite radiocarbon ages, indicating that the deposits are more than $\sim 40,000 \mathrm{yr}$ old, but amino acid ratios (Fig. 15) indicate that they are late Pleistocene (Brigham-Grette \& Hopkins, 1995; Goodfriend et al., 1996). On tectonically stable and unglaciated portions of the coasts of the Seward Peninsula and Arctic Coastal Plain, Pelukian marine deposits are found at altitudes of less than $10 \mathrm{~m}$, consistent with the inferred paleo-sea level position of $\sim 120,000$-yr-old deposits on tectonically stable coasts in middle and low latitudes. These various lines of evidence strongly support a correlation of Pelukian marine deposits to the peak of the last interglacial period, $\sim 120,000 \mathrm{yr}$ ago. Pelukian marine deposits, like their $\sim 120,000$ yr counterparts in mid-latitudes, contain a number of extralimital southern species of mollusks, indicating water temperatures higher than those of the present during the last interglacial period (Brigham-Grette \& Hopkins, 1995; Hopkins et al., 1960). Some mollusks found in Pelukian marine deposits at Nome and on St. Lawrence Island indicate that winter sea ice did not extend south of Bering Strait during the last interglacial period, a significant $(\sim 800 \mathrm{~km})$ northward retreat of its present southern wintertime limit (Brigham-Grette \& Hopkins, 1995).

\section{Sea-Level History of the Last Glaciation}

During the last glacial period, when sea level was $\sim 120 \mathrm{~m}$ lower than present, Alaska experienced a dramatic change in coastal geography compared to most of the rest of North America. The present shelf areas of the Bering and Chukchi Seas off western Alaska and eastern Siberia are shallow, generally less than $100 \mathrm{~m}$. Full-glacial sea-level lowering connected North America and Asia, creating the Bering Land Bridge (Fig. 14). During sea-level low stands of earlier glacial periods, this land bridge provided the conduit by which animals migrated from Asia to North America, possibly as long ago as early Pleistocene time (Guthrie \& Matthews, 1971). During the last glacial period, the increased land area would have affected the climate of interior Alaska profoundly, increasing continentality and aridity. The increased aridity may in part explain the last-glacial herb tundra-dominated pollen record of interior Alaska (Ager \& Brubaker, 1985). It has long been thought that the Bering Land Bridge, during last-glacial time, was the land corridor for the earliest human migrations from Asia into North America. A new hypothesis, however, suggests that humans may have arrived in North America via watercraft along the now-submerged last-glacial coastline south of the Bering Land Bridge (Dixon, 2001).

\section{Atlantic Coast}

\section{Introduction: The Nature of the Atlantic Coast Record}

The U.S. Atlantic Coastal Plain (Fig. 16) contains a rich record of Quaternary sea level change. With the exception of the carbonate deposits in southern Florida, these records are represented by a combination of erosional and clastic depositional features. Because of the low relief of this region, most of these records are found at elevations of less than $15 \mathrm{~m}$, often as laterally adjacent landforms or as superposed deposits of variable thickness and continuity. Surface expression of Pleistocene sea levels is usually seen as a series of scarps, terraces, or paleoshorelines, rarely with more than $5 \mathrm{~m}$ of relief. From the earliest work (Richards \& Judson, 1965 and references therein), many authors have interpreted the Atlantic Coastal Plain in terms of named terraces or terrace formations, as 

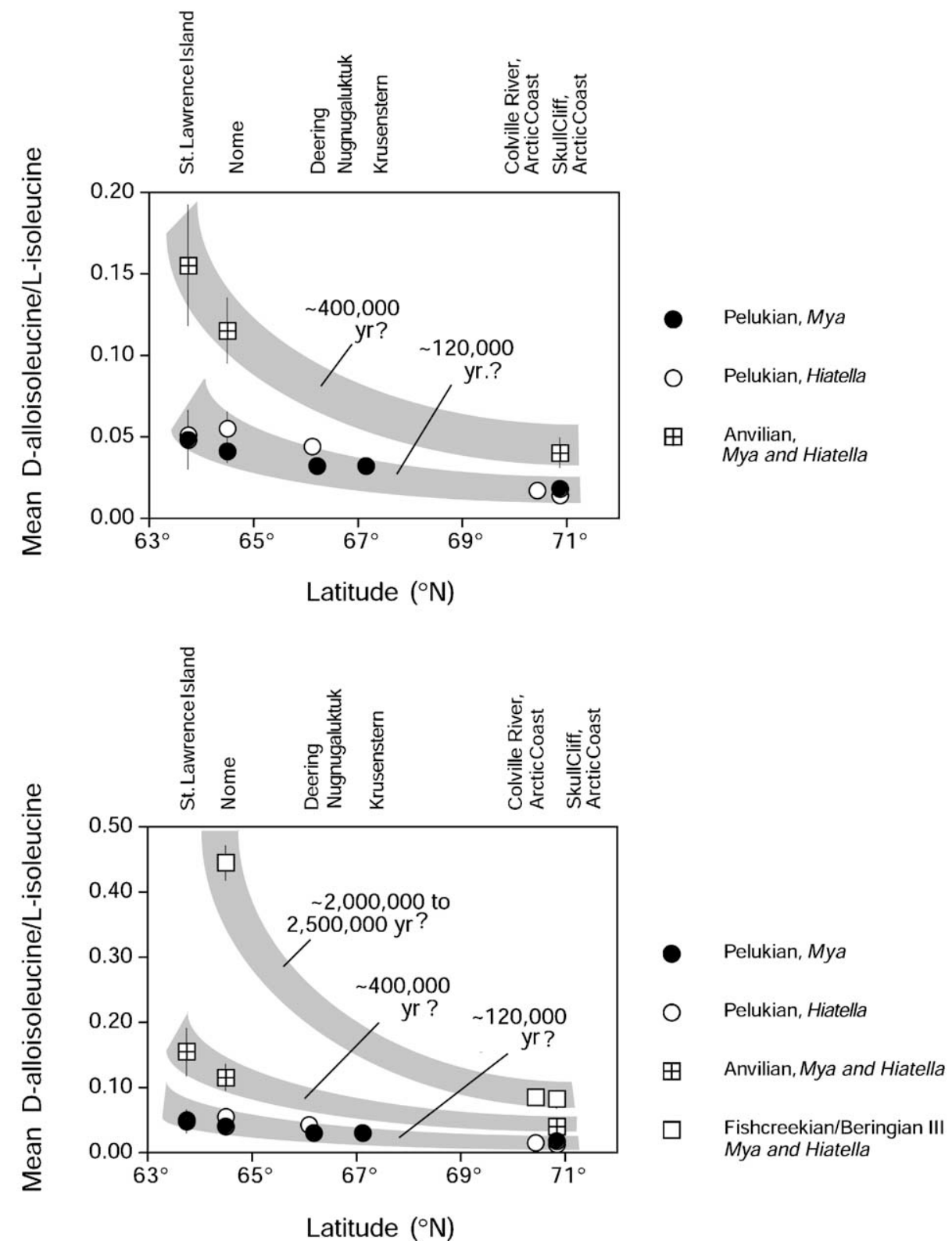

Fig. 15. Mean ratios of the amino acids D-alloisoleucine to L-isoleucine in fossil bivalves from marine deposits of Alaska, shown as a function of latitude. Upper panel is expansion of the vertical scale of the lower panel, showing only the youngest two ages of deposits. Data from Kaufman (1992), Kaufman \& Brigham-Grette (1993), and Brigham-Grette \& Hopkins (1995).

reviewed by Colquhoun et al. (1991). Several additional examples of Atlantic coast Quaternary sequences can be found in Nummendal et al. (1987) and Fletcher \& Wehmiller (1992). U-series ages have contributed to an understanding of the complex history of these terraces and terrace formations, but it has proven remarkably difficult to identify features that are clearly of early last interglacial age $(\sim 125,000 \mathrm{yr}$ or MIS 5 e), a traditional reference point for many Quaternary coastal sequences. In addition to U-series methods, amino acid racemization, radiocarbon, and occasionally paleomagnetic methods have been used for geochronologic studies of
Coastal Plain units. Middle and early Pleistocene units have often been correlated or assigned ages based on biostratigraphy (Ward et al., 1991), but these approaches rarely have the age resolution that is required to assign deposits to specific ice volume minima of the marine isotopic record.

Colquhoun et al. (1991) divided the Atlantic Coastal Plain into upper, middle, and lower segments, each segment bounded by scarps. The lower Coastal Plain contains the Pleistocene coastal record, with late Pleistocene $(<450,000$ $\mathrm{yr}$ in the system of Colquhoun) coastal units mapped seaward of several major scarps, including the prominent Suffolk 


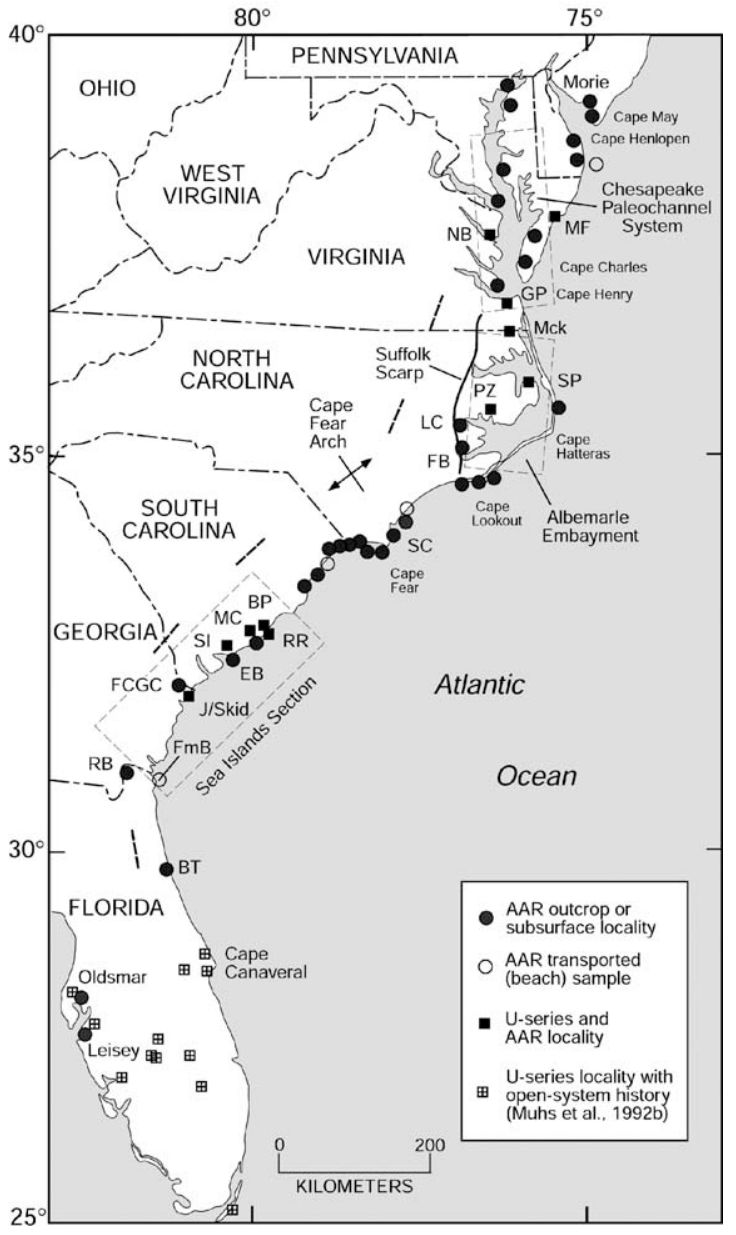

Fig. 16. Map of the U.S. Atlantic Coastal Plain. Prominent structural or geomorphic regions discussed in text (Chesapeake Paleochannel System, Albemarle Embayment, Cape Fear Arch, and Sea Islands Section). Localities with U-series or paired U-series/AAR data are identified by solid squares. Other AAR or U-series localities (e.g. Muhs et al., 1992b) are shown as indicated. AAR data from beach or shelf samples also identified separately. Locality abbreviation or relevant reference: Morie (O'Neal \& McGeary, 2002; O'Neal et al., 2000); MF, Matthews Field VA (Szabo, 1985; Groot et al., 1990); NB, Norris Bridge, VA (Szabo, 1985; Groot et al., 1990); GP, Gomez Pit, VA (Mirecki et al., 1995); Mck, Moyock, NC (Cronin et al., 1981); SP, Stetson Pit NC (York et al., 1989); PZ, Ponzer NC (Cronin et al., 1981; Szabo, 1985; Wehmiller et al., 1988); LC, Lee Creek Mine, NC; FB, Flanner Beach, NC (McCartan et al., 1982); SC, Snows Cut, NC (Dockal, 1995); BP, Berkeley Pit SC; RR, Rifle Range Pit, SC; MC, Mark Clark Pit, SC (McCartan et al., 1982); SI, Scanawah Island, SC (McCartan et al., 1982); EB Edisto Beach, SC; FCGC, Forest City Gun Club, GA; J/Skid, Jones Pit, Skidway I, GA (Hulbert \& Pratt, 1998); RB, Reids Bluff GA (Belknap, 1979; Huddleston, 1988); FrnB, Fernandina Beach, FL (Wehmiller et al., 1995); BT, Bon Terra, FL (R. Mitterer, 1975, 1995 pers. comm. to J.F. Wehmiller); Oldsmar (Olsmar 1 and 2, Karrow et al., 1996); Leisey (Jones et al., 1995).

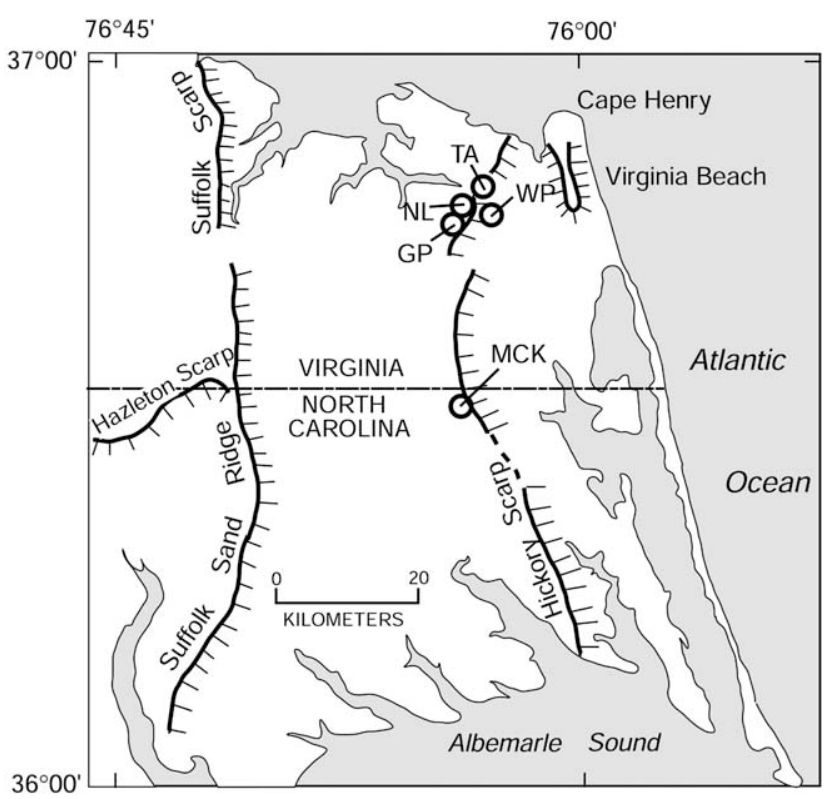

Fig. 17. Coastal plain of southeastern Virginia, with geomorphic features (from Oaks et al., 1974, their Fig. 7). See Mixon et al. (1982) for additional nomenclature on geomorphology. Locations of commercial excavations where collections for $U$-series coral dating or AAR mollusk analysis were made as follows: TA, Toy Avenue Pit; WP, Womack Pit; NL, New Light Pit; GP, Gomez Pit; MCK, Moyock Pit.

Scarp in North Carolina (Fig. 17). Pliocene and older units are found landward of the Surry Scarp, which separates the lower and middle Coastal Plain segments.

Holocene depositional environments of the Atlantic Coastal Plain are useful analogs for the Pleistocene records, which, in turn, have been influenced by the pre-Quaternary geologic framework. Hayes (1994) and Riggs et al. (1995) noted that variability in structure, antecedent topography, sediment supply, wave and tidal regimes, and Coastal Plain gradient have all affected both Holocene and Pleistocene depositional systems. South of the glacial limit in northern New Jersey, these systems include: (1) major estuaries associated with mid-Atlantic rivers (Delaware and Chesapeake bays); (2) the broad low relief Coastal Plain of North Carolina, with an extensive late Quaternary record of estuarine and shallow marine deposits; (3) the Cape Fear Arch, where the Coastal Plain gradient is steep and the Quaternary record is thin; and (4) the Sea Island section of South Carolina, Georgia, and northern Florida, where the topographic gradient is low and coast-parallel Holocene barrier-lagoon complexes are "welded" to a Pleistocene island core. The modern regional geomorphology demonstrates that older features (barriers or shorelines) exist seaward of younger back-barrier or estuarine environments, so it is likely that similar juxtapositions are preserved in the Pleistocene record. Similarly, records of Holocene sea-level rise on the Atlantic coast have been influenced by the underlying Pleistocene (or Tertiary) framework as well as regional postglacial tectonic adjustment (Peltier, 1999). 
Uranium-Series Dating of the Atlantic Coastal Plain Quaternary Coastal Record

The earliest published applications of U-series methods to Atlantic coast sites involved alpha-spectrometric analyses of reef-building corals from central and southern Florida (Broecker et al., 1965; Osmond et al., 1965), reviewed above. Most Atlantic Coastal Plain U-series studies have employed ahermatypic corals from higher-latitude sites, particularly in southeastern Virginia and central South Carolina (Figs 3, 16 and 17) (Mixon et al., 1982; Oaks et al., 1974; Szabo, 1985). Cronin et al. (1981) discussed many of the paleoenvironmental implications of these ages, and McCartan et al. (1982) discussed the relation of the U-series results to lithostratigraphic and other independent chronologic information.

Advanced analytical methods (U-series dating by TIMS) have recently been applied to additional fossil coral collections from Virginia, South Carolina, and Georgia, using fresh samples collected in direct association with mollusk specimens used for racemization analyses (Simmons et al., 1997; Wehmiller et al., 1997; York et al., 1999). There is a high degree of reliability for these samples because: (1) U contents of the corals are within the range that is typical for modern, colonial corals $(2-3 \mathrm{ppm}) ;(2){ }^{230} \mathrm{Th} /{ }^{232} \mathrm{Th}$ activity values are high, indicating little or no "inherited" ${ }^{230} \mathrm{Th}$ (a problem that had plagued previous studies: see Szabo, 1985); and (3) back-calculated initial ${ }^{234} \mathrm{U} /{ }^{238} \mathrm{U}$ values are within the range of modern sea water, indicating probable closed-system history with respect to $U$ and its long-lived daughter products. The distinguishing feature of the both the new TIMS U-series results and the earlier alpha-spectrometry results is that the ages cluster in a time range $(65,000-85,000 \mathrm{yr}$ ago, roughly correlative with substage 5a) that would not be expected for emergent units on a stable or subsiding margin, if interpreted in terms of sea level records based on isotopic or tropical coral reef eustatic models (e.g. Lambeck \& Chappell, 2001).

Only three sites on the Atlantic Coastal Plain north of Florida have yielded coral ages in the range of $\sim 125,000 \mathrm{yr}$ (MIS 5e). The few ages in this range that have been obtained, all from sites near Charleston or Myrtle Beach, South Carolina, are occasionally of questionable quality or do not unequivocally represent the age of their host unit (Hollin \& Hearty, 1990; Szabo, 1985). On Nantucket Island, Massachusetts (Fig. 3), north of the Atlantic Coastal Plain proper, there is a single U-series age of $\sim 130,000 \mathrm{yr}$ on a coral from the glacially deformed Sankaty Sand (Oldale et al., 1982). As with localities of this age in Hawaii, California, and Alaska, it contains a fauna that indicates warmer-than-present waters during this high sea stand. The absence of a prominent and well-dated $\sim 125,000 \mathrm{yr}$ unit on the Atlantic Coastal Plain, combined with the relatively large abundance of $\sim 80,000$ yr coral ages, remains unexplained in spite of many years of debate.

U-series (alpha-spectrometric) ages in the range of $\sim 200,000$ to $250,000 \mathrm{yr}$ have been obtained from sites in North and South Carolina (Hollin \& Hearty, 1990; Szabo,
1985 ) and a number of additional ages are at or near the limit of the ${ }^{230} \mathrm{Th} /{ }^{238} \mathrm{U}$ chronometer (Szabo, 1985). In some cases, the ages of these older samples (estimates range from $300,000 \mathrm{yr}$ to $>750,000 \mathrm{yr}$ ) have been derived from their ${ }^{234} \mathrm{U} /{ }^{238} \mathrm{U}$ values (Szabo, 1985). These oldest samples have been collected primarily along the Intracoastal Waterway near Myrtle Beach, South Carolina, from units known as the Socastee, Canepatch, and Waccamaw formations (Fig. 18). Because of concerns about sample reworking, stratigraphic nomenclature, and/or geochemical issues, the appropriate ages for the Socastee and Canepatch formations remain controversial (e.g. Hollin \& Hearty, 1990).

\section{Aminostratigraphy and Quaternary Chronology, Chesapeake Bay to Northern Florida}

Amino acid racemization has been applied by several workers to various stratigraphic problems in either local or regional studies of the Atlantic coastal (Corrado et al., 1986; Hollin \& Hearty, 1990; McCartan et al., 1982; Wehmiller, 1982; Wehmiller \& Belknap, 1982; Wehmiller et al., 1988, 1992). In Figs 18 through 20, we present a summary of critical results from sites that have either independent stratigraphic or Useries chronologic information that provides a framework for interpretation of the racemization data.

The racemization results plotted in Figs 18 and 19 are for a parameter identified as "VLPG," the numerical average of the $\mathrm{D} / \mathrm{L}$ values of the amino acids valine, leucine, phenylalanine, and glutamic acid, all determined by high-resolution gas chromatographic analyses of well-preserved Mercenaria, a robust bivalve mollusk commonly found in Atlantic Coastal Plain Quaternary deposits (see chromatogram in Wehmiller \& Miller, 2000). VLPG minimizes the potential variation in individual amino acid $D / L$ values that can occasionally occur, although VLPG values are always within $3 \%$ of the observed values for $D / L$ leucine, a common reference amino acid (e.g. Wehmiller \& Belknap, 1982). A conceptual model for the relation of selected VLPG values to local stratigraphic sections is shown in Fig. 18, modified from McCartan et al. (1982). Because both stratigraphic and geochronologic interpretations of the units portrayed in Fig. 18 are debated or have been modified (e.g. Hollin \& Hearty, 1990), and in some cases multiple aminozones are known to occur within a single named formation (Harris, 2000), there are optional interpretations that can be applied to individual sites in each region. Riggs et al. (1992; Fig. 2) further demonstrate the relation between local stratigraphy and geochronology for a superposed section in northeastern North Carolina.

In Fig. 19, the VLPG results are plotted vs. latitude, and each significant geomorphic or structural region of the Atlantic Coastal Plain is also identified so that racemization results can be discussed within these local frameworks. Figure 19 is plotted with VLPG values increasing downward to emphasize the superposed nature of many of the Atlantic Coastal Plain records. Results in Fig. 19 represent an ongoing effort to obtain new high-resolution chromatographic data for both earlier and more recent collections; earlier results 
Fig. 18. Schematic cross sections of three Atlantic Coastal Plain sections, showing general relations of geomorphology, stratigraphy, and $U$-series or aminostratigraphic data. Sections modified from McCartan et al. (1982), with additional $U$ series data from Hollin \& Hearty (1990). Ranges of $U$-series ages or VLPG values for a single formation identify situations where multiple ages may be found within a single mapped unit.

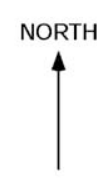

ALBERMARLE EMBAYMENT:

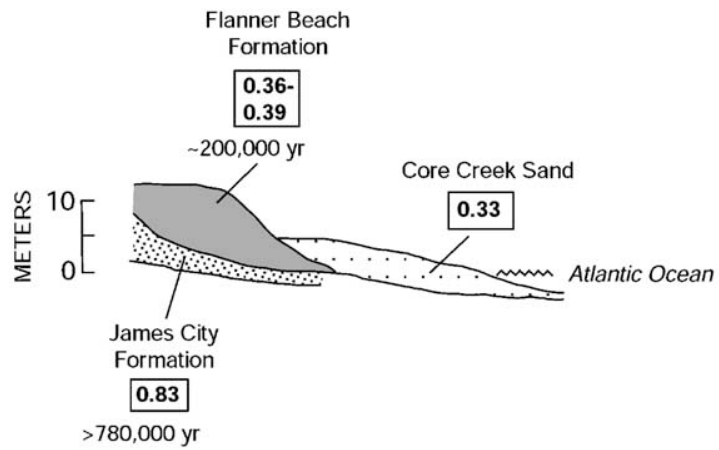

EAST $\longrightarrow$

SOUTH FLANK, CAPE FEAR ARCH:

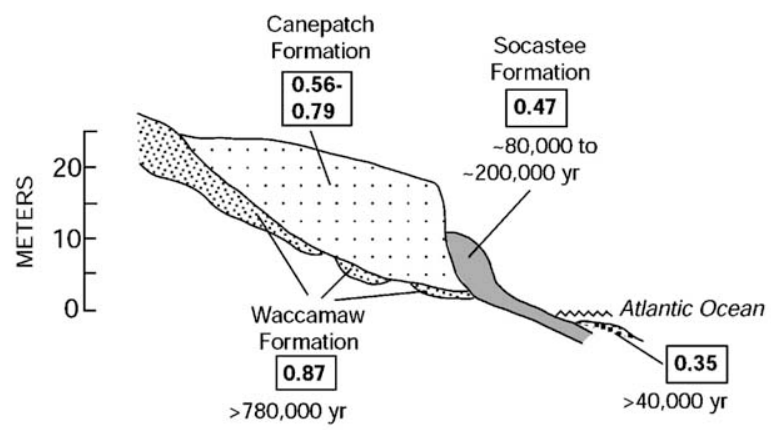

$\mathrm{EAST} \longrightarrow$

SEA ISLANDS AREA:
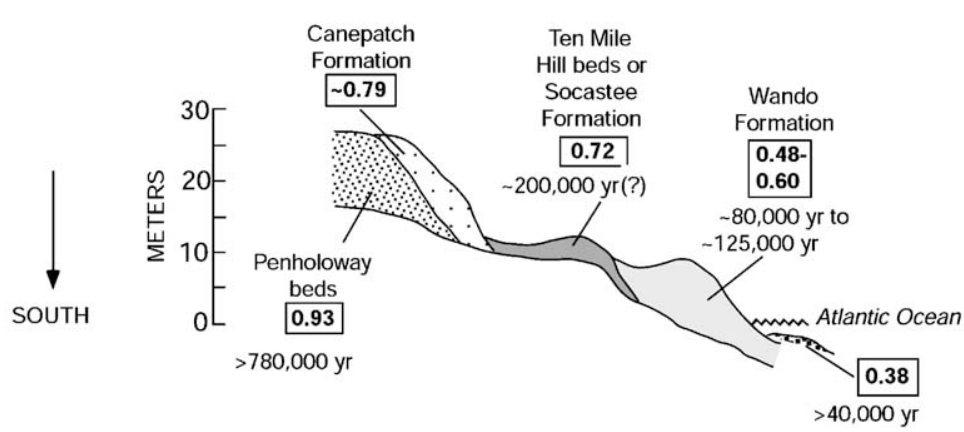

for many of these localities are published in Wehmiller et al. (1988).

Amino acid $D / L$ (VLPG) values should always increase with increasing stratigraphic age in local regions or with increasing temperature for samples of equal age (Wehmiller $\&$ Miller, 2000). Results from Stetson and Gomez pits are among the best Coastal Plain examples of superposition (Fig. 19), as VLPG values cluster into three physically superposed aminozones at each site. Additionally, Fig. 19 demonstrates general trends of increasing $D / L$ (VLPG) values with decreasing latitude or increasing temperature. However, the results in Fig. 19 raise a number of important issues regarding the potential utility of racemization for correlation or age estimation of Coastal Plain samples. These issues are probably related to geochemical, taphonomic, stratigraphic, and thermal factors (Corrado et al., 1986; Hollin \& Hearty, 1990; Wehmiller et al., 1992, 2000a, b).
Five aminozones are specifically identified in Fig. 19, and others are cited below as necessary. The area labeled “<8000 ${ }^{14} \mathrm{C}$ yr" represents results for approximately $30 \mathrm{sam}-$ ples, with radiocarbon ages ranging to $7600{ }^{14} \mathrm{C}$ yr B.P., from inner shelf and beach sites (Wehmiller \& York, 2001). The sloping band represents the upper limit of VLPG values for these Holocene samples. The shaded band labeled " 70,000 to $\sim 130,000 \mathrm{yr}$ " is an aminozone that ranges from VLPG $\sim 0.30$ at $36.5 \mathrm{~N}$ to $\sim 0.60$ at $32 \mathrm{~N}$ and includes data for all sites where mollusk samples for racemization analysis were collected in close association with corals that yielded U-series ages between $\sim 130,000$ and $\sim 70,000 \mathrm{yr}$ ago. The shaded aminozone below this one represents racemization data associated with two North Carolina sites of this apparent age (Ponzer and Flanner Beach: McCartan et al., 1982; Szabo, 1985) and the Socastee Formation at several sites along the Intracoastal Waterway near Myrtle Beach, South Carolina 
Latitude ( ${ }^{\circ}$ North)

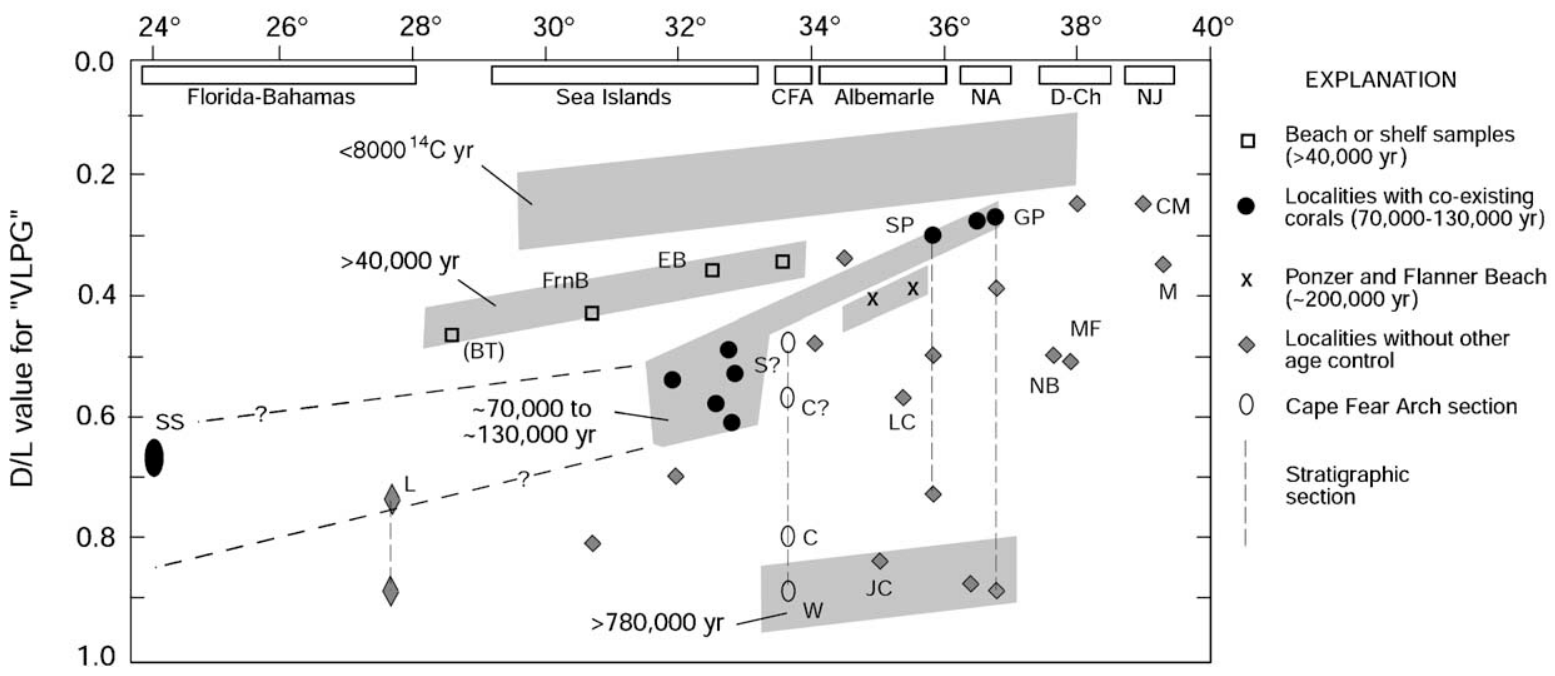

Fig. 19. Plot of VLPG vs. latitude for Atlantic Coastal Plain sites. VLPG is the average of the D/L values of valine, leucine, phenylalanine, and glutamic acid in Mercenaria. Stratigraphic or geomorphic provinces of the Coastal Plain are listed across the top of the figure. Province or locality abbreviations as in Fig. 16; CFA = Cape Fear Arch; NA = Norfolk Arch; $D$-Ch = Delmarva-Chesapeake. $S, C$, and $W$ represent Socastee, Canepatch, and Waccamaw formations, respectively (see Fig. 18). X's represent $\sim 200,000 y r$ "calibrated" results from the Albemarle Embayment, NC. Vertical dashed lines connect data points for local superposed sequences. Shaded regions represent aminozones associated with independent $U$-series ages as discussed in text. Open squares represent a beach or inner shelf aminozone that has infinite radiocarbon dates but appears younger than $\sim 80,000 y r$. The open square labeled "BT" represents data from Mitterer's (1975) Bon Terra site (pers. comm., R. Mitterer to JFW, 1992). Data point for San Salvador (SS) represents results from Chione specimens (Wehmiller et al., 1988; York et al., 2000a), increased by $\sim 10 \%$ to make them comparable with the Mercenaria results plotted here.

Fig. 20. Schematic summary of aminostratigraphic data and strontium isotopic age estimates for the Fort Thompson-Bermont section at Leisey Pit, Florida. Stratigraphic section modified from Jones et al.(1995); data from York et al. (2000a). Mean D/L leucine values have typical ranges of $5 \%$ for multiple samples.

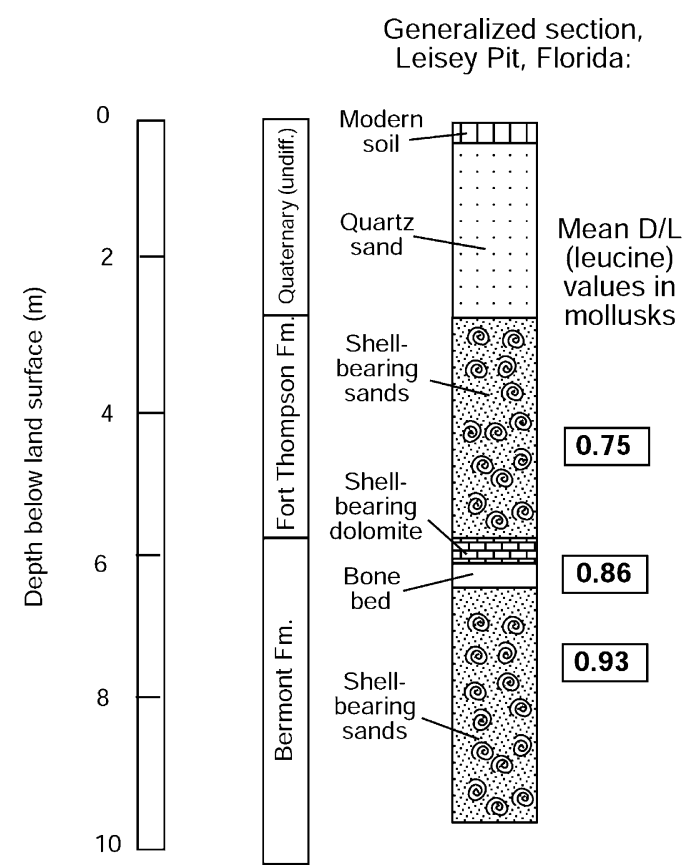

Sr-isotope age estimates from mollusks

$1,300,000 \pm 300,000 \mathrm{yr}$

$1,800,000 \pm 300,000 \mathrm{yr}$

$2,400,000 \pm 400,000 \mathrm{yr}$ 
(Fig. 15). The southward projection of this aminozone to latitude $32 \mathrm{~N}$ overlaps with the younger aminozone, and the southward projection of the " $~ 70,000$ to $\sim 130,000 \mathrm{yr}$ " aminozone does not include the well-calibrated results from San Salvador Island. These observations demonstrate a conflict that has been debated for over 20 years (reviewed by Wehmiller et al., 1992). Hollin \& Hearty (1990) resolved some of this conflict by rejecting $\sim 200,000 \mathrm{yr}$ ages as being from reworked samples, an interpretation that has major implications for all other aminostratigraphic age estimates in the region. Although theory (Wehmiller et al., 1988) predicts that aminozones should rise and diverge with decreasing latitude (increasing temperature) (e.g. Figs 11 and 15, above, and Wehmiller, 1992), this principle does not hold for the U.S. Atlantic coast, even though the modern temperature gradient is a smooth function of latitude (Wehmiller et al., 2000b). Correlation of calibrated racemization data from late Pleistocene Atlantic coast sites between Florida and Virginia instead presents a broad envelope that changes trend somewhere between 30 and $34^{\circ} \mathrm{N}$ (Corrado et al., 1986; Hollin \& Hearty, 1990; Wehmiller et al., 1988).

Aminostratigraphic results from Leisey Pit, on the southeast margin of Tampa Bay, Florida (Figs 3 and 4) demonstrate the magnitude of potential conflicts with independently calibrated results. Figure 20, modified from Jones et al., 1995) compares racemization data for the Leisey Pit section (from York et al., 2000a) with associated strontium isotopic data (Jones et al., 1995) from this same section. At Leisey Pit, a unit mapped as the Fort Thompson Formation occurs in the upper part of the section. The Fort Thompson Formation is often considered as "last interglacial" (cf. unit Q5, above) or specifically correlative with $\sim 125,000 \mathrm{yr}$. U-series dated units elsewhere in Florida (DuBar et al., 1991). In contrast, Sr-isotope age estimates for the Fort Thompson Formation at Leisey Pit are variable but are on the order of 1,000,000 years (Jones et al., 1995; York et al., 2000a). Aminostratigraphic and U-series data on mollusks (Karrow et al., 1996) from nearby excavations at Oldsmar, Florida, at the north end of Tampa Bay, combined with amino acid data from Leisey Pit argue for an age of approximately 100,000 to 200,000 yr for the Fort Thompson Formation (Wehmiller et al., 1999; York et al., 2000a). Consequently, two vastly conflicting estimates for the age of the Fort Thompson Formation at Leisey Pit can be inferred, either "late Pleistocene" ( $<200,000 \mathrm{yr})$ or "middle to early Pleistocene" ( $1,000,000 \mathrm{yr})$. The VLPG data from Leisey Pit (Fig. 19) are more consistent with the younger age estimate for the Fort Thompson Formation, especially an age around 200,000 yr when compared with the 125,000 yr calibrated results from San Salvador Island. Amino acid and Sr-isotope data are also available for the Bermont Formation, immediately underlying the Fort Thompson at Leisey (Fig. 20). These data are all stratigraphically consistent and the Sr-isotope data suggest an age of $>1,500,000 \mathrm{yr}$ for the Bermont Formation. The amino acid values for the Bermont are quite near equilibrium, so they can only be used to suggest ages greater than $\sim 750,000 \mathrm{yr}$. Mitterer's (1975) original study of Florida aminostratigraphy identified similar results for central and southern Florida.
Because of the difficulties that can arise with broad correlations of the Atlantic coast racemization data over large latitude ranges, the following discussions focus on the relation of racemization results to stratigraphic or geomorphic sequences within each of the local regions identified in Figs 18-20. These localized results can be interpreted in terms of most probable chronologies for each region, using independent age control (isotopic or biostratigraphic) where available. Age estimates proposed in the following sections could easily change if additional calibrated results became available, or if alternative models for racemization kinetics were applied (e.g. York et al., 1989).

\section{Chesapeake Bay, Delmarva Peninsula, and Norfolk Arch}

In the Chesapeake-Delmarva region, three Pleistocene aminozones are recognized (VLPG values of $0.26,0.38$, and 0.49 ), overlying Plio-Pleistocene units with near-equilibrium D/L values. At the southern end of Chesapeake Bay, the Gomez Pit section (ca. 15-20 m thick; land surface elevation $\sim+8 \mathrm{~m}$ ) provides clear evidence for the physical superposition of these aminozones (Lamothe \& Auclair, 1999; Mirecki et al., 1995), the upper one (VLPG $=0.26 \pm 0.02$ ) associated with ca. 80,000 yr U-series coral ages. This unit ("Gomez coral bed") occurs up to $7 \mathrm{~m}$ above present sea level, although the corals themselves occur between -1 and $+1 \mathrm{~m}$ (Cronin et al., 1981). The next older Gomez Pit aminozone $(\mathrm{VLPG}=0.38)$, found in an extensive oyster bed at ca. $-3 \mathrm{~m}$, represents deposition roughly 300,000-350,000 yr ago, approximately equivalent to MIS 9 (Mirecki et al., 1995). A still-older Pleistocene aminozone (VLPG $=0.49-$ not plotted in Fig. 19 for GP), seen at several sites in the region, is seen at GP in shells that are likely reworked. At the base of the GP section are nearly racemic $(\mathrm{VLPG}=0.9)$ shells from the late Pliocene Chowan River formation.

The three aminozones from southern Chesapeake Bay (VLPG $=0.26,0.38$, and 0.49$)$ are also recognized in outcrop or limited subsurface samples from sites on the Delmarva Peninsula (Groot et al., 1990). The three phases of deposition inferred from the racemization data correspond to major cut/fill sequences of the Susquehanna River paleochannel system (Colman \& Mixon, 1988; Colman et al., 1990; Oertel \& Foyle, 1995). The Chesapeake paleochannel system represents the evolution of the ancestral Susquehanna, Potomac, Rappahanock, York, and James rivers. Earlier channels of these rivers passed through the region that is now the southern Delmarva Peninsula, which has migrated southward during the mid-to-late Pleistocene evolution of this drainage pattern. Chen et al. (1995) recognized the extension of this paleochannel network onto the inner shelf of southeastern Virginia, and Knebel \& Circe (1988) identified comparable features in Delaware Bay. The VLPG value of 0.49 represents a unit that apparently fills the Exmore paleochannel, considered to be between 300,000 and 500,000 yr old, based on comparisons of racemization and U-Th data from the region. This aminozone is found at $\mathrm{MF}$ and NB (Figs 15 and 19), each site having yielded ambiguous U-series age 
estimates but with an age of $>300,000 \mathrm{yr}$ being most probable (Szabo, 1985; and pers. comm.), and also at other sites in the central Chesapeake Bay region. The two younger aminozones represent progressively younger channel-fill deposits that probably correspond with low-stand/high-stand cycles from $\sim 300,000 \mathrm{yr}$ through $\sim 100,000 \mathrm{yr}$ ago. These same two aminozones are also seen at exposures around the southern margins of Delaware Bay (CM, M on Fig. 19), where they interpreted to represent extensive late- or latemiddle Pleistocene deposition (Groot et al., 1990; O’Neal et al., 2000).

\section{Albemarle Embayment, Northeastern North Carolina}

The thick $(\sim 50 \mathrm{~m})$ Quaternary section preserved in the Albemarle Embayment preserves a racemization record spanning most of the Quaternary. The units of the Albemarle Embayment are preserved in both vertical and lateral sequences and record multiple cycles of cutting and filling during the Pleistocene (Boss et al., 2002; Riggs et al., 1992, 1995). Six Pleistocene aminozones are recognized in the sediments of the Albemarle Embayment, with approximate VLPG values of $0.3,0.38,0.49,0.56,0.72$, and 0.83 (Fig. 19). The youngest of these $(80,000 \mathrm{yr}$ by U-series dating at Moyock and Stetson Pit) represents deposition during MIS 5. The next older aminozone records MIS 7, based on data from Ponzer and Flanner Beach (McCartan et al., 1982; Szabo, 1985). Three older aminozones (VLPG 0.49, 0.56 and 0.72) are found deeper in the Stetson Pit section, near the center of the Albemarle Embayment, or in a mid-Pleistocene unit that is intermittently exposed at the Lee Creek Mine, $\sim 10 \mathrm{~km}$ east of the Suffolk Scarp (Fig. 16; Ward et al., 1991). Several of these aminozones are also seen in shallow core samples from the North Carolina inner shelf or in reworked beach specimens (Wehmiller et al., 1995). A still-older aminozone $(\mathrm{VLPG}=0.83)$ represents the James City Formation (early Pleistocene: Ward et al., 1991). The oldest aminozone (VLPG $=\sim 0.90)$ in the region represents the Pliocene/early Pleistocene Chowan River formation, sampled in both NE North Carolina and in Gomez Pit. Collectively the Albemarle Embayment VLPG data define a series of aminozones that represent multiple cycles of deposition through the Pleistocene. These aminozones may, in fact, record only a small fraction of the numerous $(\widetilde{S 15})$ transgressive records preserved in this region (Riggs et al., 1992; York et al., 1989).

The Albemarle VLPG values between $\sim 0.50$ and 0.70 fill a significant middle-to-early Pleistocene gap in the regional stratigraphy, as no named units in this interval are recognized (Soller \& Mills, 1991). This aminostratigraphy may also place an upper limit on the age of the Suffolk Scarp in eastern North Carolina (mid-Pleistocene, $~ 350,000$ to $500,000 \mathrm{yr}$, York et al., 2000b), consistent with the chronology of Colquhoun et al. (1991). More rigorous calibration of this mid-Pleistocene aminostratigraphy would help to resolve some of the aminostratigraphic correlation problems identified by the results in Fig. 19.
The Suffolk Scarp, as a prominent boundary between late and early Pleistocene units, is a major geomorphic feature of the North Carolina Coastal Plain (Brill, 1996). The southward continuation of this boundary across the Cape Fear Arch suggests that late Pleistocene units (and their associated aminozones) seen in eastern North Carolina are infrequently observed in emergent units between Cape Lookout and Cape Romain (Fig. 16), mimicking the overall outcrop pattern of pre-Quaternary units across the Cape Fear Arch (Mixon \& Pilkey, 1976; Riggs \& Belknap, 1988; Snyder et al., 1991; Wehmiller et al., 1992; York \& Wehmiller, 1992b).

\section{Cape Fear Arch}

Two shallow marine units, the Socastee and Canepatch formations, are exposed in the Intracoastal Waterway near the North Carolina-South Carolina border (Figs 16 and 18). Associated with these units are named barriers (the Myrtle Beach and Jaluco barriers, respectively, as mapped by DuBar et al., 1980). The ages of these two formations are critical for any attempt to identify paleoshorelines or correlate aminozones between the north and south flanks of the Cape Fear Arch, a region where the entire preserved Cenozoic record is much thinner than in the Albemarle Embayment. Although the stratigraphic terminology, as applied to specific exposures on the Intracoastal Waterway, has varied (Colquhoun et al., 1991; DuBar et al., 1980; Hollin \& Hearty, 1990; McCartan et al., 1982; Owens, 1989; Wehmiller et al., 1988), and the U-series chronology for these units is ambiguous (Szabo, 1985), most workers interpret the Socastee formation to be at least 200,000 yr old ( $\sim$ MIS 7$)$ and the Canepatch formation to be as much as 500,000 yr old, the latter age being derived from biostratigraphic information and associated ${ }^{234} \mathrm{U} /{ }^{238} \mathrm{U}$ values in corals (Szabo, 1985). Hollin \& Hearty (1990), however, interpreted the Socastee as 80,000 yr old (late MIS 5) and the Canepatch as 125,000 yr old (early MIS 5), an interpretation that appears consistent with aminostratigraphic comparison with the Sea Islands VLPG data summarized in Fig. 19. Hollin \& Hearty (1990) emphasized the importance of using only the youngest U-series ages found in a unit because of the potential for mixing of fossils with different ages, even though the majority of the U-series ages from Intracoastal Waterway sites (and some from other sites) would then have to be rejected. Four aminozones (VLPG values of $0.47,0.56,0.79$, and 0.87 ) are apparent in the results for the Cape Fear Arch region (Figs 18 and 19), the oldest $(0.87)$ representing the Plio-Pleistocene Waccamaw formation. The three younger aminozones have been interpreted to represent three depositional events, with ages of $>780,000$ and $\sim 460,000 \mathrm{yr}$ recorded at different Canepatch sites, and $\sim 200,000 \mathrm{yr}$ recorded at Socastee sites (Corrado et al., 1986; Wehmiller et al., 1988). Racemization age estimates for the Socastee and Canepatch are sensitive to the choice of calibration samples and/or correlations from either the north or the south: older age estimates result from comparisons with results from the Albemarle Embayment, while younger age estimates result from comparisons with the Sea 
Islands section of SC and GA. In spite of many years of study, serious ambiguities about the relation between racemization, U-series, and stratigraphic interpretations of the Socastee and Canepatch deposits remain unresolved.

\section{Sea Islands Section}

The Sea Islands section can be traced from Cape Romain, South Carolina to Cape Canaveral, Florida (Fig. 16). The typical thickness of the entire Quaternary section in the Sea Islands area is between 5 and $10 \mathrm{~m}$, although both thinner and thicker sections are found over highs and lows in the underlying Tertiary deposits (Harris, 2000). Winker \& Howard (1977) identified numerous Plio-Pleistocene paleoshorelines throughout this region.

Most of the U-series ages from the Sea Islands section cluster around 80,000 yr (MIS 5a: Wando Formation of McCartan et al., 1984). However, two older coral U-series ages $(\sim 125,000-139,000$ yr) have also been obtained from the Wando Formation (Szabo, 1985). Thus, it can be inferred that the "last interglaciation" in its broadest sense (all of MIS $5)$ may be recorded by this unit. Older ( $~ 200,000-250,000$ yr) ages have come from a unit exposed inland from the Wando Formation localities (McCartan et al., 1982; Szabo, 1985). Evidence for multiple aminozones within the Wando Formation (Corrado et al., 1986; Harris, 2000; York et al., $1999,2001)$, raises the possibility of multiple ages of fossils within this unit, but there is no single site where multiple aminozones can be directly associated with one or more U-series ages. In fact, overlapping ranges of $D / L$ values from sites with $80,000,120,000$, or $200,000 \mathrm{yr}$ U-series ages (Corrado et al., 1986; McCartan et al., 1982; Wehmiller \& Belknap, 1982) indicate that racemization data may not resolve these ages as well as has been claimed (Corrado et al., 1986; Hollin \& Hearty, 1990). Although these may be geochemical issues related to AAR (Wehmiller et al., 1993), the complexity of the Sea Islands record itself is a potential cause of the variability in apparent ages inferred from the AAR data.

Three emergent aminozones (VLPG 0.53, 0.69, and 0.80) are recognized at the southern end of the Sea Island section. The youngest of these aminozones is associated with the 80,000 yr. U-series (TIMS) coral age at Skidaway Island (Figs 16 and 19), and the others may represent terrace formations that are probably of late or late-middle Pleistocene age (Colquhoun et al., 1991; Huddleston, 1988; Markewich et al., 1992). The Skidaway Island site is a good example of the Sea Island "model," as the dated samples come from a muddy unit exposed by shallow excavation near the center of this predominately Holocene island (Hulbert \& Pratt, 1998).

A still-younger aminozone (VLPG $=0.35-0.42$, radiocarbon age $>40,000{ }^{14} \mathrm{C}$ yr B.P.) is found in reworked beach samples (EB and FrnB in Figs 16 and 19) as well as at beach and shelf sites near the North Carolina-South Carolina border (Fig. 19). The age of this aminozone is enigmatic, as it appears younger than 80,000 yr when compared with VLPG data from late Pleistocene emergent sites, but it is definitely older than $\sim 40,000{ }^{14} \mathrm{C}$ yr B.P. (Wehmiller \& York, 2001; Wehmiller et al., 1995; York \& Wehmiller, 1992a; York et al., 2001). This same aminozone is inferred from the results of Mitterer (1975) for samples collected from an emergent outcrop near Bon Terra, Florida (R.M. Mitterer, pers. comm. to J.F. Wehmiller, 1995) (BT, Fig. 16). The Bon Terra collection is particularly important, as it most likely represents the Anastasia Formation, widely considered as of "last interglacial" age. Other data from northern Florida localities (Mitterer, 1975) are consistent with this four-fold amino acid zonation for the southern portion of the Sea Islands, although specific locality information for Mitterer's collections is not available.

\section{Gulf Coast}

North and west of the carbonate-rich records of central and southern Florida (discussed above), other coastal records from the Gulf Coast include those from the Florida panhandle extending west to southern Mississippi and those along the Louisiana-Texas coast (Fig. 3). Geochronological data for Pleistocene units in this entire region are limited, particularly for emergent sequences, the focus of this review. Seismic exploration of the thick Quaternary and pre-Quaternary records in the northern Gulf of Mexico, combined with extensive marine biostratigraphy, allow high-resolution chronology for portions of the offshore record, especially on the Texas-Louisiana shelf. DuBar et al. (1991) reviewed the characteristics and nomenclature of the onshore and offshore Quaternary record of the entire region. By analogy with the Atlantic Coastal Plain, it is quite likely that Gulf Coast Quaternary deposits are equally complex and variable.

In the panhandle region of northwest Florida (Fig. 4), the number of preserved Pleistocene shoreline features has been the subject of considerable debate (Donoghue \& Tanner, 1992; Donoghue et al., 1998; Otvos, 1992, 1995), as the location of "last interglacial" features remains in doubt. Additionally, the potential age range (late Pleistocene or most of the Pleistocene) of preserved coastal features is questioned. Mollusk samples from shallow excavations in Franklin County in the Florida panhandle have yielded racemization results that imply a late Pleistocene age when compared with other data from Florida and Georgia, but correlation of these results to a specific sea level transgression is not possible (Otvos \& Wehmiller, unpublished data; Wehmiller et al., 1996).

Pleistocene coastal features on the Texas coast include the Ingleside Barrier (interpreted as broadly of "last interglacial" age by Otvos \& Howat, 1996), also referred to as the "Ingleside surface." The Ingleside surface is underlain by the Beaumont Clay, a complex unit that probably includes multiple ages of fluvial and nearshore units, perhaps representing the past 400,000 years of glacial-interglacial incision and valley filling (Blum \& Price, 1998).

Records on the Texas shelf provide an important perspective on the origin and age of both submergent and emergent landforms in the region (Anderson et al., 1996; Morton \& Price, 1987; Rodriguez et al., 2000; Suter et al., 1987). 
Valley incision, infilling, and delta construction are all recognized in various seismic studies, reinforced with core data. In one of the more provocative studies of the implications of these records for Pleistocene sea-level history, Rodriquez et al. (2000) identified a submerged escarpment and associated barrier features that indicate a shoreline at a depth (corrected for subsidence) of about $-15 \mathrm{~m}$. Based on seismic stratigraphic relations to other sequence boundaries in the record (interpreted to represent $\sim 140,000$ and $20,000 \mathrm{yr}$, or "transitional MIS 6/5e" and "MIS 2" transgressive surfaces), this paleoshoreline is interpreted to be between 35,000 and 50,000 yr old ( $\sim$ MIS 3). Its depth is significantly shallower than would be predicted from most marine isotope or dated coral reef records (e.g. Lambeck \& Chappell, 2001). Finite radiocarbon ages are consistent with this estimate (Rodriguez et al., 2000), although ages in this range are near the limit of reliability. Racemization data for mollusks from these shelf sequences and from cores beneath the Ingleside Barrier are all internally consistent with the stratigraphic position of the samples (Wehmiller et al., 2000a). Kinetic modeling is also consistent with an age of between 40,000 and 80,000 yr for the $-15 \mathrm{~m}$ paleoshoreline (Wehmiller et al., 2000a).

Elsewhere on the Gulf of Mexico shelf, Schroeder et al. (1995) used radiocarbon dating of oyster shells to produce a rough curve of postglacial sea-level rise and a more uncertain record for the time interval between about 27,000 and $40,000{ }^{14} \mathrm{C}$ yr B.P. Although many shell radiocarbon ages in this range can be challenged (Bloom, 1983a), some paired AAR/radiocarbon (AMS) analyses of massive and well-preserved shells from shelf/beach environments indicate that ages in this range may be valid (Wehmiller \& York, 2001; Wehmiller et al., 1995). Because all of the dated shells of Schroeder et al. (1995) were transported to some extent, a precise sea level curve cannot be constructed.

\section{Summary: Atlantic and Gulf Coasts}

\section{Early Pleistocene to Last Interglacial Period}

Age assignments for Atlantic coast marine units rely upon either biostratigraphic, radiometric, or suitably calibrated racemization modeling. All of these methods have significant uncertainties, particularly for the earlier Pleistocene, and racemization models are quite subjective, especially when used to correlate over broad latitude ranges. Nevertheless, for the Atlantic Coastal Plain, early to middle Pleistocene depositional records appear to be preserved throughout the region. Notable examples include the older parts of the Albemarle Embayment section in North Carolina and the Waccamaw formation in northeastern South Carolina. Late-middle Pleistocene, or pre-last interglacial units, include paleochannel fill in the Chesapeake Bay region, and U-series and racemizationdated units from the Albemarle and Cape Fear Arch regions. Determining the origin(s) and age(s) of the Suffolk Scarp would provide major insights into the history of sea level change on the Atlantic Coastal Plain. The Beaumont Clay on the Texas coast also appears to represent a complex of multiple units representing several transgressive-regressive cycles during the middle- to late Pleistocene.

\section{Last Interglacial and Last Glacial Periods}

Atlantic coast sites with U-series ages representing early MIS $5(\sim 125,000 \mathrm{yr})$ are rare north of the Florida Keys; where found, these units are at roughly the same elevation (all within ca. 6-8 $\mathrm{m}$ of present sea level) as those dated at 80,000 yr. These observations have been the focus of debate about the Atlantic Coastal Plain geochronology for nearly three decades. Nevertheless, a high sea level at $\sim 80,000 \mathrm{yr}$ is consistent with similar data from Bermuda (Muhs et al., 2002b) and some data from the U.S. Pacific Coast (Fig. 13). Emergent shoreline features are found throughout the Gulf and Atlantic coastal plains, and in the absence of numerical geochronologic data, it is common to assign "last interglacial" ages to features found at elevations up to approximately $+8 \mathrm{~m}$.

The current elevations of emergent Atlantic coast paleoshorelines or shallow marine units U-series dated to late MIS $5(80,000 \mathrm{yr})$ are higher than expected from marine isotope curves or dated tropical coral terrace records (Lambeck \& Chappell, 2001; Shackleton, 1987). Records on the New Jersey, Maryland, and Texas shelves (Sheridan et al., 2000; Rodriguez et al., 2000; Toscano \& York, 1992) also indicate sea levels during either late MIS 5 or MIS 3 that were higher than predicted from marine isotope curves. These observations suggest that major sections of the Atlantic and Gulf coasts, although considered as passive margin regions, may have been influenced by a combination of postglacial isostatic adjustment (through multiple glacial cycles), hydroisostasy, and shelf sediment loading.

\section{Records of Holocene Sea-Level Rise, Atlantic and Gulf Coasts}

Preserved records on continental shelves provide a general insight into the potential complexity of emergent records on any low gradient coastal plain. The youngest portions of these sequences represent the processes that occurred during last glacial low-stands and the rise in sea level since the last glacial maximum. In many cases, these are depositional records, preserved in areas of relatively large sediment supply. Examples include, but are not limited to, the inner shelves of New Jersey (Sheridan et al., 2000), Maryland (Toscano, 1992; Toscano \& York, 1992), North Carolina (Boss et al., 2002; Riggs et al., 1995), large estuaries (Colman et al., 1992) and thick sections on the Texas shelf (Anderson et al., 1996; Rodriguez et al., 2000). Where sediment supply is more limited (such as the shelves of South Carolina and Georgia), extensive recycling of shelf sediments during multiple Quaternary transgressions is inferred from local stratigraphic sections where 1-2 $\mathrm{m}$ of preserved section may represent the entire Quaternary (Gayes et al., 1992; Harris et al., 2000; Heron 
et al., 1984; Hine \& Snyder, 1985; Macintyre et al., 1978; Pilkey et al., 1981).

Records of Holocene sea-level rise on the Atlantic and Gulf coasts are numerous, having been obtained in order to understand local or regional histories of coastal evolution or geophysical models of postglacial isostatic adjustment (e.g. Peltier, 1999). Major processes affecting these records include isostatic rebound in glaciated areas (Kelley et al., 1992), steady subsidence associated with forebulge collapse in regions proximal to glacier advance (Kraft et al., 1987), and, occasionally, rises of sea level to near present level during the middle Holocene in regions farther from glacial influence (Blum \& Carter, 2000). Holocene depositional records that provide good models for Pleistocene sequences in a particular region are especially important. Good examples include channel erosion and filling in Chesapeake Bay (Colman et al., 1990, 1992) and in Albemarle Sound (Riggs et al., 1992, 1995), and Holocene coastal environments of the Florida peninsula (Davis et al., 1992). In each of these regions, good analogies between preserved Pleistocene and Holocene records can be recognized.

\section{Unresolved Issues on the Atlantic Coastal Plain}

The following are three major unresolved geochronological issues related to the Pleistocene of the Atlantic Coastal Plain. Quite likely similar issues will arise for Gulf Coast sites as additional chronologic data (or samples for dating) become available for this region, but limited results prevent more specific conclusions.

(1) Identification of 125,000 yr erosional and depositional records using geomorphic and geochronologic analysis. Detailed mapping and dating in selected regions (such as the Cape Fear Arch and Albemarle Embayment) where both surface landforms and subsurface units can be clearly mapped is a high priority for establishing confidence in any of the Atlantic or Gulf coast chronologic records.

(2) Reconciling the elevation of the 80,000 -yr-old units with the sea-level record from marine isotope and tropical coral reef records. The similar elevation of these units, and of possible 125,000-yr units (all within $6 \mathrm{~m}$ ) from Virginia to Georgia (and also Bermuda), must be interpreted in the context of glacial-margin tectonics and hydroisostatic effects.

(3) Understanding the age-resolution capabilities of amino acid racemization methods, including assessing the reality and significance of the "offshore aminozone" found between North Carolina and Georgia. Inconsistencies in correlation of racemization data from region to region appear to contradict the stratigraphic coherence of racemizatoin data in local regions with common temperature and depositional histories. Continued refinement of racemization kinetic modeling by comparison with rigorous independent calibration is needed.

\section{Summary}

Much progress has been made in the past three decades in our understanding of the Quaternary sea-level history of U.S. coastlines. Two complimentary dating methods, U-series analyses of fossil corals and amino acid racemization of fossil mollusks, have generated hundreds of numerical and correlated ages. These data have allowed lateral correlation of marine deposits on the Pacific and Atlantic coasts and the Hawaiian Islands, as well as on the Bering Sea and Arctic Ocean coasts of Alaska.

Many of the sea-level high stands of the Quaternary are recorded in the reef record of the tectonically stable Florida Keys. Stratigraphic studies show that deposits of pre-lastinterglacial high stands are present, although dating has yet to establish the precise timing of these deposits. Nevertheless, preliminary ages suggest that two high sea stands of the mid-Pleistocene are recorded on the Florida Keys, perhaps on the order of $\sim 300,000-340,000$ and 220,000-230,000 yr. Corals in reefs of two high sea stands of the last interglacial complex, the $\sim 80,000$ and $\sim 120,000$ yr stands, are present in this island chain. Offshore, Holocene reefs of the Florida Keys and mainland extend the Barbados record of sea-level rise since the last glacial period up to present sea level.

Reefs and coral-bearing marine deposits, both emergent and submergent, have been identified, mapped and dated in the Hawaiian Islands. On the island of Oahu, the Waimanalo Limestone was deposited during the peak of the last interglacial complex. Because Oahu is uplifting only very slowly, the range of U-series ages for this deposit is a good estimate of the duration of the peak of the last interglacial period. Results of recent high-precision dating indicate that the peak of the last interglacial period could have lasted at least 15,000 yr and possibly longer. Waimanalo Limestone deposits contain a significant number of extralimital southern mollusks, indicating warmer-than-present waters during the last interglacial period. The "big island" of Hawaii, unlike Oahu, is undergoing long-term Quaternary subsidence, due to volcanic loading. As a result, submerged reefs off Hawaii mark deglacial periods and yield a record of such events for more than 400,000 yr. The island of Lanai has long been the object of study because of high-elevation marine deposits. A novel hypothesis that these deposits were formed by a "giant wave" generated by a submarine landslide was proposed as a challenge to a decades-old concept that sea level was much higher than present. This hypothesis has in turn been challenged by new mapping and dating that suggest that the deposits were elevated due to lithospheric flexure, in response to the subsidence of the island of Hawaii, in turn induced by volcanic loading.

Multiple marine terraces on the Pacific Coast record a long history of sea-level high stands superimposed on longterm crustal uplift. Pre-last-interglacial high sea stands are recorded on the coast of California and several fossil-bearing localities in southern California hold promise for unraveling middle and early Pleistocene sea-level history. A high terrace on San Nicolas Island dates to $~ 500,000-600,000 \mathrm{yr}$ ago and suggests that much of the sea-level history of the middle 
Pleistocene may be recorded in a series of lower terraces. U-series analyses show that marine terraces from both the $\sim 80,000$ - and $\sim 120,000$-yr-old sea-level high stands of the last interglacial complex, long recognized on tropical coasts, are also present on the Pacific Coast. The $\sim 120,000$ yr high sea stand lasted at least $8000-10,000 \mathrm{yr}$ on the Pacific Coast, based on the range of individual coral ages. It was a major interglacial period that is distinguished by the presence of extralimital southern mollusks, indicating eastern Pacific Ocean water temperatures warmer than present. The $\sim 80,000 \mathrm{yr}$ high sea stand could also have been on the order of 8000-10,000 yr long, but it is distinguished by the presence of extralimital northern mollusks, indicating water temperatures cooler than present. Reworking of $\sim 120,000$ yr fossils during the $\sim 100,000 \mathrm{yr}$ high stand occurred on the Pacific Coast, based on U-series dating of individual corals. This reworking suggests that sea level at $\sim 100,000$ yr ago may have been close to that of today. "Capture" of the $\sim 120,000 \mathrm{yr}$ high sea stand during the $\sim 100,000 \mathrm{yr}$ high stand may also explain the mixture of extralimital southern and extralimital northern fossils in some deposits.

As with the coasts of California, Hawaii, and Florida, the peak of the last interglacial period is recorded on the Bering Sea and Arctic Ocean coasts of Alaska. Although corals have not been found in these deposits, amino acid ratios, non-finite radiocarbon ages, and terrace elevations all indicate that the "Pelukian" high sea stand corresponds to the peak of the last interglacial period. Similar to low-latitude and mid-latitude marine deposits of this high sea stand, Pelukian deposits of Alaska contain a number of extralimital southern species of mollusks, indicating warmer-than-modern water temperatures. In addition, an older high sea stand, that is probably on the order of $\sim 400,000 \mathrm{yr}$ old, may record another major interglacial period, also with warmer-than-modern water temperatures.

The Atlantic Coastal Plain of the eastern United States has been one of the most challenging regions for studies of past sea levels. Because this coast is on a passive continental margin, sea-level records are complex: long-term uplift does not "isolate" individual high stands of sea as distinct terraces in the manner that is typical for the Pacific Coast. Many transgressive-regressive cycles are preserved at roughly the same elevations, resulting in a highly complex stratigraphic record. Nevertheless, amino acid racemization studies have shown that there is a rich record of Quaternary sea-level fluctuations, at least as far back as the middle Pleistocene and more likely the early Pleistocene.

An unexpected result of recent studies on the Atlantic Coastal Plain is that, unlike the other coasts of the U.S., records of the peak last-interglacial high sea stand of $\sim 120,000$ yr ago have been remarkably difficult to find. The few U-series ages that have been reported for this high sea stand are equivocal. In contrast, the $\sim 80,000 \mathrm{yr}$ high sea stand is recorded as low-elevation (but emergent) marine deposits in Virginia, North Carolina, South Carolina and Georgia. Individual coral ages of this high sea stand are very similar to those on the Pacific Coast and indicate that the $\sim 80,000 \mathrm{yr}$ high stand could have lasted as long as $\sim 10,000 \mathrm{yr}$. The presence of $\sim 80,000 \mathrm{yr}$ deposits at or even above sea level on a tectonically stable coast is a major challenge to widely held views that this sea stand was significantly lower than present sea level.

The longer-term Quaternary sea-level record of the Atlantic Coastal Plain is apparent in thick stratigraphic sequences, multiple aminozones ranging back to the early Pleistocene, and some independent chronologic control for units that date to $>750,000 \mathrm{yr}$. Shore-parallel correlation of these deposits is also possible, as has been done on the Pacific Coast. The actual length of the Quaternary sea-level record in this region, as shown by amino acid racemization data, depends on the choice of calibration samples and on either a "short" or "long" time constant for racemization. Consequently, age estimates based on racemization results might vary by $100 \%$ or more. The "short" chronology suggests that the Atlantic Coastal Plain record spans only $\sim 500,000 \mathrm{yr}$, whereas the "long" chronology would suggest a considerably greater part of the Quaternary is represented.

Certain results of sea-level studies on the coasts of the United States challenge the Milankovitch (1941) theory of climate change, as interpreted from the deep-sea oxygen isotope record. The duration of the peak of the last interglacial period (MIS 5e), when sea level was as high or higher than present, is interpreted from the oxygen isotope record to be on the order of only a few thousand years (Imbrie et al., 1984; Martinson et al., 1987). In contrast, the coral record from Oahu, Hawaii indicates that sea level as high or higher than present could have lasted 15,000-20,000 yr. The U-series ages from both Oahu and California also suggest that sea level was relatively high about $115,000 \mathrm{yr}$ ago, a time that the oxygen isotope record would suggest that sea level was relatively low. U-series ages of $\sim 80,000 \mathrm{yr}$ for corals from the tectonically stable Atlantic Coastal Plain and the slowly uplifting Pacific Coast suggest that sea level at that time was near present, whereas the oxygen isotope record suggests that sea level was then well below present. The reasons for the discrepencies between the coastal sea-level record and the deep-sea oxygen isotope record are not understood, but provide an important challenge to future investigations on the coasts of the United States.

\section{Acknowledgments}

Work on sea-level history by Muhs and Simmons was supported by the Earth Surface Dynamics Program of the U.S. Geological Survey and is a contribution to the LITE (Last Interglacial: Timing and Environment) Project. Studies by Wehmiller and York were supported by the National Science Foundation. We thank Robert S. Thompson, Richard Z. Poore, and two anonymous referees for helpful reviews of an earlier version of this paper.

\section{References}

Addicott, W.O. (1966). Late Pleistocene marine paleoecology and zoogeography in central California. U.S. Geological Survey Professional Paper 523-C, pp. C1-C21. 
Ager, T.A. \& Brubaker, L. (1985). Quaternary palynology and vegetational history of Alaska. In: Bryant, V.M., Jr. \& Holloway, R.G. (Eds), Pollen records of Late-Quaternary North American sediments. Dallas, Texas, American Association of Stratigraphic Palynologists Foundation, pp. 353-383.

Aharon, P. \& Chappell, J. (1986). Oxygen isotopes, sea level changes and the temperature history of a coral reef environment in New Guinea over the last $10^{5}$ years. Palaeogeography, Palaeoclimatology, Palaeoecology, 56, 337-379.

Alexander, C.S. (1953). The marine and stream terraces of the Capitola-Watsonville area. University of California Publications in Geography, 10, 1-44.

Anderson, J.B., Abdulah, K., Sarzalejo, S., Siringan, F. \& Thomas, M.A. (1996). Late Quaternary sedimentation and high-resolution sequence stratigraphy of the east Texas shelf. In: De Batist, M. \& Jacobs, P. (Eds), Geology of siliciclastic shelf seas. Geological Society Special Publication, 117, pp. 95-124.

Anderson, R.S. \& Menking, K.M. (1994). The Quaternary marine terraces of Santa Cruz, California: Evidence for coseismic uplift on two faults. Geological Society of America Bulletin, 106, 649-664.

Bard, E., Hamelin, B., Fairbanks, R.G. \& Zindler, A. (1990). Calibration of the ${ }^{14} \mathrm{C}$ timescale over the past 30,000 years using mass spectrometric U-Th ages from Barbados corals. Nature, 345, 405-410.

Belknap, D.F. (1979). Application of amino acid geochronology to stratigraphy of late Cenozoic marine units of the Atlantic coastal plain [Ph.D. thesis]. Newark, University of Delaware, $348 \mathrm{pp}$.

Bender, M.L., Fairbanks, R.G., Taylor, F.W., Matthews, R.K., Goddard, J.G. \& Broecker, W.S. (1979). Uranium-series dating of the Pleistocene reef tracts of Barbados, West Indies. Geological Society of America Bulletin, 90(Pt. I), 577-594.

Berger, A. \& Loutre, M.F. (1991). Insolation values for the climate of the last 10 million years. Quaternary Science Reviews, 10, 297-317.

Bernard, H.A. \& LeBlanc, R.J. (1965). Résumé of the Quaternary geology of the northwestern Gulf of Mexico province. In: Wright, H.E., Jr. \& Frey, D.G. (Eds), The Quaternary of the United States. Princeton, Princeton University Press, pp. 137-185.

Bloom, A.L. (1983a). Sea level and coastal morphology of the United States through the late Wisconsin glacial maximum. In: Porter, S.C. (Ed.), Late Quaternary Environments of the United States, Vol. 1, The late Pleistocene. University of Minnesota Press, Minneapolis, pp. 215-229.

Bloom, A.L. (1983b). Sea level and coastal changes. In: Wright, H.E., Jr. (Ed.), Late Quaternary Environments of the United States, Vol. 2, The Holocene. University of Minnesota Press, Minneapolis, pp. 42-51.

Bloom, A.L., Broecker, W.S., Chappell, J.M.A., Matthews, R.K. \& Mesolella, K.J. (1974). Quaternary sea level fluctuations on a tectonic coast: New ${ }^{230} \mathrm{Th} /{ }^{234} \mathrm{U}$ dates from the Huon Peninsula, New Guinea. Quaternary Research, 4, 185-205.
Blum, M.D. \& Carter, A.E. (2000). Middle Holocene evolution of the central Texas coast. Gulf Coast Association of Geological Societies Transactions, L, 331-341.

Blum, M.D. \& Price, D.M. (1998). Quaternary alluvial plain construction in response to interacting glacio-eustatic and climatic controls, Texas Gulf Coastal Plain. In: Shanley, K. \& McCabe, P. (Eds), Relative Roles of Eustasy, Climate, and Tectonism in Continental Rocks: SEPM (Society for Sedimentary Geology) Special Publication, 59, pp. 31-48.

Boss, S.K., Hoffman, C.W. \& Cooper, B. (2002). Influence of fluvial processes on the Quaternary geology framework of the continental shelf, North Carolina, USA. Marine Geology, 183, 45-65.

Bradley, W.C. \& Griggs, G.B. (1976). Form, genesis, and deformation of central California wave-cut platforms. Geological Society of America Bulletin, 87, 433-449.

Brill, A.L. (1996). The Suffolk Scarp, a Pleistocene barrier island in Beaufort and Pamlico Counties, NC [M.S. thesis], Duke University, 154 pp.

Brigham-Grette, J. \& Hopkins, D.M. (1995). Emergent marine record and paleoclimate of the last interglaciation along the northwest Alaskan coast. Quaternary Research, 43, 159-173.

Broecker, W.S. \& Thurber, D.L. (1965). Uranium-series dating of corals and oolites from Bahaman and Florida Key limestones. Science, 149, 58-60.

Broecker, W.S., Thurber, D.L., Goddard, J., Ku, T.-L., Matthews, R.K. \& Mesolella, K.J. (1968). Milankovitch hypothesis supported by precise dating of coral reefs and deep-sea sediments. Science, 159, 297-300.

Bryan, W.B. \& Stephens, R.S. (1993). Coastal bench formation at Hanauma Bay, Oahu. Geological Society of America Bulletin, 105, 377-386.

Buddemeier, R.W. \& Smith, S.V. (1988). Coral reef growth in an era of rapidly rising sea-level. Coral Reefs, 7, 51-56.

Calhoun, R.S. \& Fletcher, C.H., III (1996). Late Holocene coastal plain stratigraphy and sea-level history at Hanalei, Kauai, Hawaiian Islands. Quaternary Research, 45, 47-58.

Chappell, J. (1974a). Geology of coral terraces, Huon Peninsula, New Guinea: A study of Quaternary tectonic movements and sea level changes. Geological Society of America Bulletin, 85, 553-570.

Chappell, J. (1974b). Late Quaternary glacio- and hydroisostasy on a layered Earth. Quaternary Research, 4, 429-440.

Chappell, J. \& Shackleton, N.J. (1986). Oxygen isotopes and sea level. Nature, 324, 137-140.

Chen, J.H., Curran, H.A., White, B. \& Wasserburg, G.J. (1991). Precise chronology of the last interglacial period: ${ }^{234} \mathrm{U}-{ }^{230} \mathrm{Th}$ data from fossil coral reefs in the Bahamas. Geological Society of America Bulletin, 103, 82-97.

Chen, Z.-Q., Hobbs, C.H., III, Wehmiller, J.F. \& Kimball, S.M. (1995). Late Quaternary paleochannel systems on the continental shelf, south of the Chesapeake Bay entrance. Journal of Coastal Research, 11, 605-614.

Cheng, H., Edwards, R.L., Hoff, J., Gallup, C.D., Richards, D.A. \& Asmerom, Y. (2000). The half-lives of uranium-234 and thorium-230. Chemical Geology, 169, 17-33. 
Clark, J.A., Farrell, W.E. \& Peltier, W.R. (1978). Global changes in postglacial sea level: A numerical calculation. Quaternary Research, 9, 265-287.

Clark, P.U. \& Mix, A.C. (2002). Ice sheets and sea level of the Last Glacial Maximum. Quaternary Science Reviews, 21, 1-7.

Colman, S.M. \& Mixon, R.B. (1988). The record of major Quaternary sea-level changes in a large coastal plain estuary, Chesapeake Bay, eastern United States. Palaeogeography, Palaeoclimatology, Palaeoecology, 68, 99-116.

Colman, S.M., Halka, J.P., Hobbs, C.H., III, Mixon, R.B. \& Foster, D.S. (1990). Ancient channels of the Susquehanna River beneath Chesapeake Bay and the Delmarva Peninsula. Geological Society of America Bulletin, 102, 1268-1279.

Colman, S.M., Halka, J.P. \& Hobbs, C.H., III (1992). Patterns and rates of sediment accumulation in the Chesapeake Bay during the Holocene rise in sea level. In: Fletcher, C.H., III \& Wehmiller, J.F. (Eds), Quaternary Coasts of the United States: Marine and Lacustrine Systems. SEPM (Society for Sedimentary Geology) Special Publication, 48, pp. 101-111.

Colquhoun, D.J., Johnson, G.H., Peebles, P.C., Huddleston, P.F. \& Scott, T. (1991). Quaternary geology of the Atlantic coastal plain. In: Morrison, R.B. (Ed.), Quaternary nonglacial geology: Conterminus U.S. Boulder, Colorado, Geological Society of America, Geology of North America, K-2, pp. 629-650.

Coniglio, M. \& Harrison, R.S. (1983). Facies and diagenesis of late Pleistocene carbonates from Big Pine Key, Florida. Bulletin of Canadian Petroleum Geology, 31, 135-147.

Corrado, J.C., Weems, R.E., Hare, P.E. \& Bambach, R.K. (1986). Capabilities and limitations of applied aminostratigraphy, as illustrated by analyses of Mulinia lateralis from the late Cenozoic marine beds near Charleston, South Carolina. South Carolina Geology, 30, 19-46.

Cronin, T.M., Szabo, B.J., Ager, T.A., Hazel, J.E. \& Owens, J.P. (1981). Quaternary climates and sea levels of the U.S. Atlantic Coastal Plain. Science, 211, 233-240.

Curray, J.R. (1965). Late Quaternary history, continental shelves of the United States. In: Wright, H.E., Jr. \& Frey, D.G. (Eds), The Quaternary of the United States. Princeton, Princeton University Press, pp. 723-735.

Davis, R.A., Jr., Hine, A.C. \& Shinn, E.A. (1992). Holocene coastal development on the Florida peninsula. In: Fletcher, C.H., III \& Wehmiller, J.F. (Eds), Quaternary Coasts of the United States: Marine and Lacustrine Systems. SEPM (Society for Sedimentary Geology) Special Publication, 48, pp. 193-212.

Dixon, E.J. (2001). Human colonization of the Americas: Timing, technology and process. Quaternary Science Reviews, 20, 277-299.

Dockal, J.A. (1995). Documentation and evaluation of radiocarbon dates from the Cape Fear Coquina (Late Pleistocene) of Snows Cut, New Hanover County, North Carolina. Southeastern Geology, 35, 169-186.

Dodge, R.E., Fairbanks, R.G., Benninger, L.K. \& Maurrasse, F. (1983). Pleistocene sea levels from raised coral reefs of Haiti. Science, 219, 1423-1425.
Donoghue, J.F., Stapor, F.W. \& Tanner, W.F. (1998). Discussion of: Otvos, E.G. (1995). Multiple Pliocene-Quaternary marine highstands, northeast Gulf Coastal Plain-fallacies and facts. Journal of Coastal Research, 14, 669674.

Donoghue, J.F. \& Tanner, W.F. (1992). Quaternary terraces and shorelines of the panhandle Florida region. In: Fletcher, C.H., III \& Wehmiller, J.F. (Eds), Quaternary Coasts of the United States: Marine and Lacustrine Systems. SEPM (Society for Sedimentary Geology) Special Publication, 48, pp. 233-242.

DuBar, J.R., DuBar, S.S., Ward, L.W., Blackwelder, B.W., Abbot, W.H. \& Huddleston, P.F. (1980). Cenozoic biostratigraphy of the Carolina outer coastal plain. In: Frey, R.W. (Ed.), Excursions in Southeastern Geology, 1, Field Trip 9, Geological Society of America Annual Meeting, Atlanta, Georgia (and American Geological Institute, Falls Church, Virginia), pp. 179-236.

DuBar, J.R., Ewing, T.E., Lundelius, E.L. Jr., Otvos, E.G. \& Winker, C.D. (1991). Quaternary geology of the Gulf of Mexico coastal plain. In: Morrison, R.B. (Ed.), Quaternary Non-Glacial Geology: Conterminus U.S. Boulder, Colorado, Geological Society of America, Geology of North America, K-2, pp. 583610.

Easton, W.H. \& Olson, E.A. (1976). Radiocarbon profile of Hanauma Reef, Oahu, Hawaii. Geological Society of America Bulletin, 87, 711-719.

Edwards, R.L., Cheng, H., Murrell, M.T. \& Goldstein, S.J. (1997). Protactinium-231 dating of carbonates by thermal ionization mass spectrometry: Implications for Quaternary climate change. Science, 276, 782-786.

Emiliani, C. (1955). Pleistocene temperatures. Journal of Geology, 63, 538-578.

Enos, P. \& Perkins, R.D. (1977). Quaternary sedimentation in south Florida. Geological Society of America Memoir, 147, 198.

Fairbanks, R.G. (1989). A 17,000-year glacio-eustatic sea level record: influence of glacial melting rates on the Younger Dryas event and deep-ocean circulation. Nature, 342, 637-642.

Fleming, K., Johnston, P., Zwartz, D., Yokoyama, Y., Lambeck, K. \& Chappell, J. (1998). Refining the eustatic sea-level curve since the Last Glacial Maximum using farand intermediate-field sites. Earth and Planetary Science Letters, 163, 327-342.

Fletcher, C.H., III \& Jones, A.T. (1996). Sea-level highstand recorded in Holocene shoreline deposits on Oahu, Hawaii. Journal of Sedimentary Research, 66, 632-641.

Fletcher, C.H., III \& Wehmiller, J.F. (Eds) (1992). Quaternary coasts of the United States: Marine and lacustrine systems. SEPM (Society for Sedimentary Geology) Special Publication, 48, pp. 1-450.

Fruijtier, C., Elliot, T. \& Schlager, W. (2000). Massspectrometric ${ }^{234} \mathrm{U}_{-}{ }^{230} \mathrm{Th}$ ages from the Key Largo Formation, Florida Keys, United States: Constraints on diagenetic age disturbance. Geological Society of America Bulletin, 112, 267-277. 
Gallup, C.D., Cheng, H., Taylor, F.W. \& Edwards, R.L. (2002). Direct determination of the timing of sea level change during Termination II. Science, 295, 310-313.

Gallup, C.D., Edwards, R.L. \& Johnson, R.G. (1994). The timing of high sea levels over the past 200,000 years. Science, 263, 796-800.

Gayes, P.T., Scott, D.B., Collins, E.S. \& Nelson, D.D. (1992). A late Holocene sea-level fluctuation in South Carolina. In: Fletcher, C.H., III \& Wehmiller, J.F. (Eds), Quaternary Coasts of the United States: Marine and Lacustrine Systems. SEPM (Society for Sedimentary Geology) Special Publication, 48, pp. 155-160.

Goodfriend, G.A., Brigham-Grette, J. \& Miller, G.H. (1996). Enhanced age resolution of the marine Quaternary record in the Arctic using aspartic acid racemization dating of bivalve shells. Quaternary Research, 45, 176-187.

Grant, L.B., Mueller, K.J., Gath, E.M., Cheng, H., Edwards, R.L., Munro, R. \& Kennedy, G.L. (1999). Late Quaternary uplift and earthquake potential of the San Joaquin Hills, southern Los Angeles Basin, California. Geology, 27, 1031-1034.

Groot, J.J., Ramsey, K.W. \& Wehmiller, J.F. (1990). Ages of the Bethany, Beverdam \& Omar Formations of southern Delaware. Delaware Geological Survey Report of Investigations, No. 47, 1-19.

Grossman, E.E. \& Fletcher, C.H., III (1998). Sea level higher than present 3500 years ago on the northern main Hawaiian Islands. Geology, 26, 363-366.

Grossman, E.E., Fletcher, C.H., III \& Richmond, B.M. (1998). The Holocene sea-level highstand in the equatorial Pacific: Analysis of the insular paleosea-level database. Coral Reefs, 17, 309-327.

Guthrie, R.D. \& Matthews, J.V., Jr. (1971). The Cape Deceit fauna - early Pleistocene mammalian assemblage from the Alaskan Arctic. Quaternary Research, 1, 474-510.

Halley, R.B., Vacher, H.L. \& Shinn, E.A. (1997). Geology and hydrogeology of the Florida Keys. In: Vacher, H.L. \& Quinn, T. (Eds), Geology and hydrogeology of carbonate islands. Developments in Sedimentology, 54, Amsterdam, Elsevier, pp. 217-248.

Hanson, K.L., Lettis, W.R., Wesling, J.R., Kelson, K.I. \& Mezger, L. (1992). Quaternary marine terraces, south-central coastal California: Implications for crustal deformation and coastal evolution. In: Fletcher, C.H., III \& Wehmiller, J.F. (Eds), Quaternary coasts of the United States: Marine and lacustrine systems. SEPM (Society for Sedimentary Geology) Special Publication, 48, pp. 323-332.

Harris, M.S. (2000). Influence of a complex geologic framework on Quaternary coastal evolution: An example from Charleston, South Carolina [Ph.D. thesis]. Newark, University of Delaware, $330 \mathrm{pp}$.

Harris, M.S., Wehmiller, J.F., York, L.L. \& Gayes, P.T. (2000). Quaternary evolution of the lower coastal plain and continental shelf near Charleston, South Carolina: stratigraphic construction, geomorphic expression \& geochronology. Geological Society of America Abstracts with Programs, 32, 2, 24.
Harrison, R.S. \& Coniglio, M. (1985). Origin of the Pleistocene Key Largo Limestone, Florida Keys. Bulletin of Canadian Petroleum Geology, 33, 350-358.

Hayes, M.O. (1994). The Georgia Bight barrier system. In: Davis, R.A., Jr. (Ed.), Geology of Holocene Barrier Island Systems. Berlin, Springer-Verlag, pp. 233-304.

Hearty, P.J. (2002). The Ka'ena highstand of O'ahu, Hawai'i: Further evidence of Antarctic ice collapse during the middle Pleistocene. Pacific Science, 56, 65-81.

Hearty, P.J., Kindler, P., Cheng, H. \& Edwards, R.L. (1999). A +20 m middle Pleistocene sea-level highstand (Bermuda and the Bahamas) due to partial collapse of Antarctic ice. Geology, 27, 375-378.

Henderson, G.M. \& Slowey, N.C. (2000). Evidence from U-Th dating against Northern Hemisphere forcing of the penultimate deglaciation. Nature, 404, 61-66.

Heron, S.D., Moslow, T.F., Berelson, W.M., Herbert, J.R., Steele, G.A. \& Susman, K.R. (1984). Holocene sedimentation of a wave-dominated barrier island shoreline: Cape Lookout, North Carolina. Marine Geology, 60, 413-434.

Hine, A.C. \& Snyder, S.W. (1985). Coastal lithosome preservation: Evidence from the shoreface and inner continental shelf off Bogue Banks, N.C. Marine Geology, 63, 307-330.

Hoffmeister, J.E. \& Multer, H.G. (1968). Geology and origin of the Florida Keys. Geological Society of America Bulletin, 79, 1487-1502.

Hoffmeister, J.E., Stockman, K.W. \& Multer, H.G. (1967). Miami Limestone of Florida and its Recent Bahamian counterpart. Geological Society of America Bulletin, 78, 175-190.

Hollin, J.T. \& Hearty, P.J. (1990). South Carolina interglacial sites and stage 5 sea levels. Quaternary Research, 33, 1-17.

Hopkins, D.M. (1967). Quaternary marine transgressions in Alaska. In: Hopkins, D.M. (Ed.), The Bering Land Bridge. Stanford, California, Stanford University Press, pp. 451-484.

Hopkins, D.M. (1973). Sea level history in Beringia during the past 250,000 years. Quaternary Research, 3, 520-540.

Hopkins, D.M., MacNeil, F.S. \& Leopold, E.B. (1960). The coastal plain at Nome, Alaska: A late Cenozoic type section for the Bering Strait region. In: International Geological Congress, Report of the Twenty-First Session Norden, Part IV, Chronology and Climatology of the Quaternary, Copenhagen, Denmark, pp. 46-57.

Hopkins, D.M., Rowland, R.W., Echols, R.E. \& Valentine, P.C. (1974). An Anvilian (early Pleistocene) marine fauna from western Seward Peninsula, Alaska. Quaternary Research, 4, 441-470.

Huddleston, P.F. (1988). A revision of the lithostratigraphic units of the coastal plain of Georgia: The Miocene through Holocene. Georgia Geological Survey Bulletin, 104.

Hulbert, R.C., III \& Pratt, A.E. (1998). New Pleistocene (Rancholabrean) vertebrate faunas from coastal Georgia. Journal of Vertebrate Paleontology, 18, 412-429.

Imbrie, J., Hays, J.D., Martinson, D.G., McIntyre, A., Mix, A.C., Morley, J.J., Pisias, N.G., Prell, W.L. \& Shackleton, N.J. (1984). The orbital theory of Pleistocene climate: Support from a revised chronology of the marine $\delta^{18} \mathrm{O}$ record. 
In: Berger, A., Imbrie, J., Hays, J., Kukla, G. \& Saltzman, B. (Eds), Milankovitch and Climate: Understanding the Response to Astronomical Forcing. Dordrecht: D. Reidel Publishing Company, pp. 269-305.

Jones, D.S., Mueller, P.A., Acosta, T. \& Shuster, R.D. (1995). Strontium isotope stratigraphy and age estimates for the Leisey shell pit faunas, Hillsborough County, Florida: Bulletin of the Florida Museum of Natural History. Biological Sciences, 37(pt. 1), 93-105.

Kaufman, D. (1992). Aminostratigraphy of PliocenePleistocene high-sea-level deposits, Nome coastal plain and adjacent nearshore area, Alaska. Geological Society of America Bulletin, 104, 40-52.

Kaufman, D. \& Brigham-Grette, J. (1993). Aminostratigraphic correlations and paleotemperature implications, Pliocene-Pleistocene high-sea-level deposits, northwestern Alaska. Quaternary Science Reviews, 12, 21-33.

Kaufman, D.S., Walter, R.C., Brigham-Grette, J. \& Hopkins, D.M. (1991). Middle Pleistocene age of the Nome River glaciation, northwestern Alaska. Quaternary Research, 36, 277-293.

Karrow, P.F., Morgan, G.S., Portell, R.W., Simons, E. \& Auffenberg, K. (1996). Middle Pleistocene (early Rancholabrean) vertebrates and associated marine and non-marine invertebrates from Oldsmar, Pinellas County, Florida. In: Stewart, K.M. \& Seymour, K.L. (Eds), Palaeoecology and Palaeoenvironments of Late Cenozoic Mammals: Tributes to the Career of C.S. (Rufus) Churcher. Toronto, University of Toronto Press, pp. 97-113.

Kelley, J.T., Dickson, S.M., Belknap, D.F. \& Stuckenrath, R., Jr. (1992). Sea-level change and late Quaternary sediment accumulation on the southern Maine inner continental shelf. In: Fletcher, C.H., III \& Wehmiller, J.F. (Eds), Quaternary Coasts of the United States: Marine and Lacustrine Systems. SEPM (Society for Sedimentary Geology) Special Publication, 48, pp. 23-34.

Kelsey, H.M. (1990). Late Quaternary deformation of marine terraces on the Cascadia subduction zone near Cape Blanco, Oregon. Tectonics, 9, 983-1014.

Kelsey, H.M. \& Bockheim, J.G. (1994). Coastal landscape evolution as a function of eustasy and surface uplift rate, Cascadia margin, southern Oregon. Geological Society of America Bulletin, 106, 840-854.

Kelsey, H.M., Ticknor, R.L., Bockheim, J.G. \& Mitchell, C.E. (1996). Quaternary upper plate deformation in coastal Oregon. Geological Society of America Bulletin, 108, 843-860.

Kennedy, G.L., Lajoie, K.R. \& Wehmiller, J.F. (1982). Aminostratigraphy and faunal correlations of late Quaternary marine terraces, Pacific Coast, USA. Nature, 299, 545-547.

Kern, J.P. \& Rockwell, T.K. (1992). Chronology and deformation of marine shorelines, San Diego County, California. In: Fletcher, C.H., III \& Wehmiller, J.F. (Eds), Quaternary Coasts of the United States: Marine and Lacustrine Systems. SEPM (Society for Sedimentary Geology) Special Publication, 48, pp. 377-382.

Kidson, C. (1982). Sea level changes in the Holocene. Quaternary Science Reviews, 1, 121-151.
Knebel, H.J. \& Circe, R.C. (1988). Late Pleistocene drainage systems beneath Delaware Bay. Marine Geology, 78, 285-302.

Kosuge, S. (1969). Fossil mollusks of Oahu, Hawaii Islands. Bulletin of the National Science Museum [Tokyo, Japan], 12, 783-794.

Kraft, J.C., Chrzastowski, M.J., Belknap, D.F., Toscano, M.A. \& Fletcher, C.H., III (1987). The transgressive barrier-lagoon coast of Delaware: Morphostratigraphy, sedimentary sequences and responses to relative rise in sea level. In: Nummendal, D., Pilkey, O.H. \& Howard, J.D (Eds), Sea-Level Fluctuation and Coastal Evolution. SEPM (Society for Sedimentary Geology) Special Publication, 41, pp. 129-143.

Ku, T.-L. (1968). Protactinium 231 method of dating coral from Barbados island. Journal of Geophysical Research, 73, 2271-2276.

Ku, T.-L., Ivanovich, M. \& Luo, S. (1990). U-series dating of last interglacial high sea stands: Barbados revisited. Quaternary Research, 33, 129-147.

Ku, T.-L. \& Kern, J.P. (1974). Uranium-series age of the upper Pleistocene Nestor terrace, San Diego, California. Geological Society of America Bulletin, 85, 1713-1716.

Ku, T.-L., Kimmel, M.A., Easton, W.H. \& O’Neil, T.J. (1974). Eustatic sea level 120,000 years ago on Oahu, Hawaii. Science, 183, 959-962.

Lajoie, K.R., Kern, J.P., Wehmiller, J.F., Kennedy, G.L., Mathieson, S.A., Sarna-Wojcicki, A.M., Yerkes, R.F. \& McCrory, P.A. (1979). Quaternary marine shorelines and crustal deformation, San Diego to Santa Barbara, California. In: Abbott, P.L. (Ed.), Geological Excursions in the Southern California Area. San Diego, Dept. of Geological Sciences, San Diego State University, pp. 3-15.

Lajoie, K.R., Ponti, D.J., Powell, C.L., II, Mathieson, S.A. \& Sarna-Wojcicki, A.M. (1991). Emergent marine strandlines and associated sediments, coastal California; A record of Quaternary sea-level fluctuations, vertical tectonic movements, climatic changes, and coastal processes. In: Morrison, R.B. (Ed.), Quaternary Nonglacial Geology; Conterminous U.S. Boulder, Colorado, Geological Society of America, Boulder, Colorado, The Geology of North America, K-2, pp. 190-203.

Lambeck, K. \& Chappell, J. (2001). Sea level change through the last glacial cycle. Science, 292, 679-686.

Lamothe, M. \& Auclair, M. (1999). A solution to anomalous fading and age shortfalls in optical dating of feldspar minerals. Earth and Planetary Science Letters, 171, 319-323.

Lidz, B.H., Hine, A.C., Shinn, E.A. \& Kindinger, J.L. (1991). Multiple outer-reef tracts along the south Florida bank margin: Outlier reefs, a new windward-margin model. Geology, 19, 115-118.

Lidz, B.H., Shinn, E.A., Hine, A.C. \& Locker, S.D. (1997). Contrasts within an outlier-reef system: Evidence for differential Quaternary evolution, south Florida windward margin, U.S.A. Journal of Coastal Research, 13, 711-731.

Lighty, R.G., Macintyre, I.G. \& Stuckenrath, R. (1978). Submerged early Holocene barrier reef south-east Florida shelf. Nature, 276, 59-60. 
Lighty, R.G., Macintyre, I.G. \& Stuckenrath, R. (1982). Acropora palmata reef framework: A reliable indicator of sea level in the western Atlantic for the past 10,000 years. Coral Reefs, 1, 125-130.

Ludwig, K.R., Muhs, D.R., Simmons, K.R., Halley, R.B. \& Shinn, E.A. (1996). Sea level records at $\sim 80 \mathrm{ka}$ from tectonically stable platforms: Florida and Bermuda. Geology, 24, 211-214.

Ludwig, K.R., Muhs, D.R., Simmons, K.R. \& Moore, J.G. (1992a). Sr-isotope record of Quaternary marine terraces on the California coast and off Hawaii. Quaternary Research, 37, 267-280.

Ludwig, K.R., Simmons, K.R., Szabo, B.J., Winograd, I.J., Landwehr, J.M., Riggs, A.C. \& Hoffman, R.J. (1992b). Mass-spectrometric ${ }^{230} \mathrm{Th}^{234}{ }^{2} \mathrm{U}-{ }^{238} \mathrm{U}$ dating of the Devils Hole calcite vein. Science, 258, 284-287.

Ludwig, K.R., Szabo, B.J., Moore, J.G. \& Simmons, K.R. (1991). Crustal subsidence rate off Hawaii determined from ${ }^{234} \mathrm{U}^{238} \mathrm{U}$ ages of drowned coral reefs. Geology, 19, $171-174$

Lundberg, J. \& McFarlane, D. (2002). Isotope stage 11 sea level in the Netherlands Antilles. Geological Society of America Abstracts with Programs, 34, 6, 31.

Macintyre, I.G. (1988). Modern coral reefs of western Atlantic: New geological perspective. The American Association of Petroleum Geologists Bulletin, 72, 1360-1369.

Macintyre, I.G., Pilkey, O.H. \& Stuckenrath, R. (1978). Relict oysters on the United States Atlantic continental shelf: a reconsideration of their usefulness in understanding late Quaternary sea-level history. Geological Society of America Bulletin, 89, 277-282.

Macintyre, I.G., Raymond, B. \& Stuckenrath, R. (1983). Recent history of a fringing reef, Bahia Salina del Sur, Vieques Island, Puerto Rico. Atoll Research Bulletin, 268, 1-9.

Markewich, H.W., Hacke, C.M. \& Huddleston, P.F. (1992). Emergent Pliocene and Pleistocene sediments of southeastern Georgia: an anomalous, fossil-poor, clastic section. In: Fletcher, C.H., III \& Wehmiller, J.F. (Eds), Quaternary Coasts of the United States: Marine and Lacustrine Systems. SEPM (Society for Sedimentary Geology) Special Publication, 48, pp. 173-192.

Martinson, D.G., Pisias, N.G., Hays, J.D., Imbrie, J., Moore, T.C., Jr. \& Shackleton, N.J. (1987). Age dating and the orbital theory of the ice ages: Development of a high-resolution 0 to 300,000-year chronostratigraphy. Quaternary Research, 27, 1-29.

Matthews, R.K. (1973). Relative elevation of late Pleistocene high sea level stands: Barbados uplift rates and their implications. Quaternary Research, 3, 147-153.

McCartan, L., Lemon, E.M., Jr. \& Weems, R.E. (1984). Geologic map of the area between Charleston and Orangeburg, South Carolina. U.S. Geological Survey Miscellaneous Investigations Series, Map I-1472, scale 1:250,000.

McCartan, L., Owens, J.P., Blackwelder, B.W., Szabo, B.J., Belknap, D.F., Kriausakul, N., Mitterer, R.M. \& Wehmiller, J.F. (1982). Comparison of amino acid racemization geochronometry with lithostratigraphy, biostratigraphy, uranium-series coral dating, and magnetostratigraphy in the Atlantic coastal plain of the southeastern United States. Quaternary Research, 18, 337-359.

Merritts, D. \& Bull, W.B. (1989). Interpreting Quaternary uplift rates at the Mendocino triple junction, northern California, from uplifted marine terraces. Geology, 17, 1020-1024.

Mesolella, K.J., Matthews, R.K., Broecker, W.S. \& Thurber, D.L. (1969). The astronomical theory of climatic change: Barbados data. Journal of Geology, 77, 250-274.

Milankovitch, M.M. (1941). Canon of Insolation and the Ice Age Problem. Beograd, Koniglich Serbische Akademie (English translation by the Israel Program for Scientific Translations, Jerusalem, Israel (1969)).

Milne, G.A., Mitrovica, J.X. \& Schrag, D.P. (2002). Estimating past continental ice volume from sea-level data. Quaternary Science Reviews, 21, 361-376.

Mirecki, J.E., Wehmiller, J.F. \& Skinner, A. (1995). Geochronology of Quaternary coastal units, southeastern Virginia. Journal of Coastal Research, 11, 1135-1144.

Mitrovica, J.X. \& Peltier, W.R. (1991). On post-glacial geoid subsidence over the equatorial oceans. Journal of Geophysical Research, 96, 20,053-20,071.

Mitterer, R.M. (1975). Ages and diagenetic temperatures of Pleistocene deposits of Florida based upon isoleucine epimerization in Mercenaria. Earth and Planetery Science Letters, 28, 275-282.

Mixon, R.B. \& Pilkey, O.H. (1976). Reconnaissance geology of the submerged and emerged Coastal Plain province, Cape Lookout area, North Carolina. U.S. Geological Survey Professional Paper, 859, pp. 1-45.

Mixon, R.B., Szabo, B.J. \& Owens, J.P. (1982). Uraniumseries dating of mollusks and corals, and age of Pleistocene deposits, Chesapeake Bay area, Virginia and Maryland. U.S. Geological Survey Professional Paper 1067-E, pp. $1-18$.

Moore, G.W. \& Moore, J.G. (1988). Large-scale bedforms in boulder gravel produced by giant waves in Hawaii. Geological Society of America Special Paper 229, pp. 101-110.

Moore, J.G. (1970). Relationship between subsidence and volcanic load, Hawaii. Bulletin Volcanologique, 34, $562-576$.

Moore, J.G. \& Fornari, D.J. (1984). Drowned reefs as indicators of the rate of subsidence of the island of Hawaii. Journal of Geology, 92, 752-759.

Moore,J.G. \& Moore, G.W.(1984). Deposit from a giant wave on the island of Lanai, Hawaii. Science, 226, 1312-1315.

Moore, J.G., Normark, W.R. \& Szabo, B.J. (1990). Reef growth and volcanism on the submarine southwest rift zone of Mauna Loa, Hawaii. Bulletin of Volcanology, 52 , $375-380$.

Morton, R.A. \& Price, W.A. (1987). Late Quaternary sea-level fluctuations and sedimentary phases of the Texas coastal plain and shelf. In: Nummendal, D., Pilkey, O.H. \& Howard, J.D. (Eds), Sea-Level Fluctuation and Coastal Evolution. SEPM (Society for Sedimentary Geology) Special Publication, 41, pp. 182-198.

Muhs, D.R. (2000). Dating marine terraces with relative-age and correlated-age methods. In: Noller, J.S., Sowers, J.M. \& Lettis, W.R. (Eds), Quaternary Geochronology, 
Applications and Methods. American Geophysical Union Reference Shelf, 4, 434-446.

Muhs, D.R. (2002). Evidence for the timing and duration of the last interglacial period from high-precision uraniumseries ages of corals on tectonically stable coastlines. Quaternary Research, 58, 36-40.

Muhs, D.R., Kennedy, G.L. \& Rockwell, T.K. (1994). Uranium-series ages of marine terrace corals from the Pacific coast of North America and implications for last-interglacial sea level history. Quaternary Research, 42, 72-87.

Muhs, D.R., Kelsey, H.M., Miller, G.H., Kennedy, G.L., Whelan, J.F. \& McInelly, G.W. (1990). Age estimates and uplift rates for late Pleistocene marine terraces: Southern Oregon portion of the Cascadia forearc. Journal of Geophysical Research, 95, 6685-6698.

Muhs, D.R., Miller, G.H., Whelan, J.F. \& Kennedy, G.L. (1992a). Aminostratigraphy and oxygen isotope stratigraphy of marine terrace deposits, Palos Verdes Hills and San Pedro areas, Los Angeles County, California. In: Fletcher, C.H., III \& Wehmiller, J.F. (Eds), Quaternary Coasts of the United States: Marine and Lacustrine Systems. SEPM (Society for Sedimentary Geology) Special Publication, 48, pp. 363-376.

Muhs, D.R., Simmons, K.R., Kennedy, G.L. \& Rockwell, T.K. (2002b). The last interglacial period on the Pacific Coast of North America: Timing and Paleoclimate. Geological Society of America Bulletin, 114, 569592.

Muhs, D.R., Simmons, K.R., Kennedy, G.L., Ludwig, K.R. \& Groves, L.T. (2002c). A cool eastern Pacific Ocean at the close of the last interglacial complex, $\sim 80,000 \mathrm{yr}$ B.P. Geological Society of America Abstracts with Programs, 34, 6, 130 .

Muhs, D.R., Simmons, K.R. \& Steinke, B. (2002a). Timing and warmth of the last interglacial period: New U-series evidence from Hawaii and Bermuda and a new fossil compilation for North America. Quaternary Science Reviews, 21, 1355-1383.

Muhs, D.R. \& Szabo, B.J. (1994). New uranium-series ages of the Waimanalo Limestone, Oahu, Hawaii: Implications for sea level during the last interglacial period. Marine Geology, 118, 315-326.

Muhs, D.R., Szabo, B.J., McCartan, L., Maat, P.B., Bush, C.A. \& Halley, R.B. (1992b). Uranium-series age estimates of corals from Quaternary marine sediments of southern Florida. Florida Geological Survey Special Publication, 36, pp. 41-50.

Multer, H.G., Gischler, E., Lundberg, J., Simmons, K.R. \& Shinn, E.A. (2002). Key Largo Limestone revisited: Pleistocene shelf-edge facies, Florida Keys, USA. Facies, 46, 229-272.

Nakata, M. \& Lambeck, K. (1989). Late Pleistocene and Holocene sea-level change in the Australian region and mantle rheology. Geophysical Journal International, 96, 497-517.

Nummendal, D., Pilkey, O.H. \& Howard, J.D. (Eds) (1987). Sea-level fluctuation and coastal evolution. SEPM (Society for Sedimentary Geology) Special Publication, 41, pp. $1-267$.

Oaks, R.Q., Coch, N.K., Sanders, J.E. \& Flint, R.F. (1974). Post-Miocene shorelines and sea levels, southeastern Virginia. In: Oaks, R.Q., Jr. \& DuBar, J.R. (Eds), Post-Miocene Stratigraphy, Central and Southern Atlantic Coastal Plain. Logan, Utah, Utah State University Press, pp. 53-87.

Oertel, G.F. \& Foyle, A.M. (1995). Drainage displacement by sea-level fluctuation at the outer margin of the Chesapeake Seaway. Journal of Coastal Research, 11, 583-604.

Oldale, R.N., Valentine, P.C., Cronin, T.M., Spiker, E.C., Blackwelder, B.W., Belknap, D.F., Wehmiller, J.F. \& Szabo, B.J. (1982). Stratigraphy, structure, absolute age, and paleontology of the upper Pleistocene deposits at Sankaty Head, Nantucket Island, Massachusetts. Geology, 10, 246-252.

O'Neal, M.L., Wehmiller, J.F. \& Newell, W.L. (2000). Amino acid geochronology of Quaternary coastal terraces on the northern margin of Delaware Bay, southern New Jersey, USA. In: Goodfriend, G.A., Collins, M.J., Fogel, M.L., Macko, S.A. \& Wehmiller, J.F. (Eds), Perspectives in Amino Acid and Protein Geochemistry. Oxford, Oxford University Press, pp. 301-319.

O’Neal, M.L. \& McGeary, S. (2002). Late Quaternary stratigraphy and sea-level history of the northern Delaware Bay margin, southern New Jersey, USA: a ground penetrating radar analysis of composite Quaternary coastal terraces. Quaternary Science Reviews, 21, 929-946.

Osmond, J.K., Carpenter, J.R. \& Windom, H.L. (1965). $\mathrm{Th}^{230} / \mathrm{U}^{234}$ age of the Pleistocene corals and oolites of Florida. Journal of Geophysical Research, 70, 1843-1847.

Ota, Y. \& Omura, O. (1992). Contrasting styles and rates of tectonic uplift of coral reef terraces in the Ryukyu and Daito Islands, southwestern Japan. Quaternary International, 15/16, 17-29.

Otvos, E.G. (1992). Quaternary evolution of the Apalachicola coast, northeastern Gulf of Mexico. In: Fletcher, C.H., III \& Wehmiller, J.F. (Eds), Quaternary Coasts of the United States: Marine and Lacustrine Systems. SEPM (Society for Sedimentary Geology) Special Publication 48, pp. 221-232.

Otvos, E.G. (1995). Multiple Pliocene-Quaternary marine highstands, northeast Gulf of Mexico coastal plain - fallacies and facts. Journal of Coastal Research, 11, 984-1002.

Otvos, E.G. \& Howat, W.E. (1996). South Texas Ingleside Barrier: coastal sediment cycles and vertebrate fauna: late Pleistocene stratigraphy revised. Transactions of the Gulf Coast Association of Geological Societies, XLVI, 333-344.

Owens, J.P. (1989). Geologic map of the Cape Fear region, Florence $1^{\circ} \times 2^{\circ}$ quadrangle and northern half of the Georgetown $1^{\circ} \times 2^{\circ}$ quadrangle, North Carolina and South Carolina. U.S. Geological Survey Miscellaneous Investigations Map I-1948-A, scale 1:250,000.

Pilkey, O.H., Blackwelder, B.W., Knebel, H.J. \& Ayers, M.W. (1981). The Georgia embayment continental shelf: Stratigraphy of a submergence. Geological Society America Bulletin, 92(Pt. I), 52-63.

Peltier, W.R. (1994). Ice age paleotopography. Science, 265, 195-201. 
Peltier, W.R. (1996). Mantle viscosity and ice-age ice sheet topography. Science, 273, 1359-1364.

Peltier, W.R. (1999). Global sea level rise and glacial isostatic adjustment. Global and Planetary Change, 20, 93-133.

Peltier, W.R. (2002). On eustatic sea level history: Last glacial maximum to Holocene. Quaternary Science Reviews, 21 , 377-396.

Péwé, T.L., Hopkins, D.M. \& Giddings, J.L. (1965). The Quaternary geology and archaeology of Alaska. In: Wright, H.E., Jr. \& Frey, D.G. (Eds), The Quaternary of the United States. Princeton, Princeton University Press, pp. 355-374.

Poore, R.Z. \& Dowsett, H.J. (2001). Pleistocene reduction of polar ice caps evidence from Cariaco Basin marine sediments. Geology, 29, 71-74.

Richards, H.G. \& Judson, S. (1965). The Atlantic coastal plain and the Appalachian highlands in the Quaternary. In: Wright, H.E., Jr. \& Frey, D.G. (Eds), The Quaternary of the United States. Princeton, Princeton University Press, pp. 129-136.

Riggs, S.R. \& Belknap, D.F. (1988). Upper Cenozoic processes and environments of continental margin sedimentation: Eastern United States. In: Sheridan, R.E. \& Grow, J.A. (Eds), The Atlantic Continental Margin: U.S. Boulder, Colorado, Geological Society of America, Geology of North America, I-2, pp. 131-176.

Riggs, S.R., York, L.L., Wehmiller, J.F. \& Snyder, S.W. (1992). Depositional patterns resulting from high frequency Quaternary sea-level fluctuations in northeastern North Carolina. In: Fletcher, C.H., III \& Wehmiller, J.F. (Eds), Quaternary Coasts of the United States: Marine and Lacustrine Systems. SEPM (Society for Sedimentary Geology) Special Publication, 48, pp. 141-153.

Riggs, S.R., Cleary, W.J. \& Snyder, S.W. (1995). Influence of inherited geologic framework on barrier shoreface morphology and dynamics. Marine Geology, 126, 213-234.

Rockwell, T.K., Muhs, D.R., Kennedy, G.L., Hatch, M.E., Wilson, S.H. \& Klinger, R.E. (1989). Uranium-series ages, faunal correlations and tectonic deformation of marine terraces within the Agua Blanca fault zone at Punta Banda, northern Baja California, Mexico. In: Abbott, P.L. (Ed.), Geologic Studies in Baja California. Los Angeles, Pacific Section, Society of Economic Paleontologists and Mineralogists, pp. 1-16.

Rockwell, T.K., Nolan, J.M., Johnson, D.L. \& Patterson, R.H. (1992). Ages and deformation of marine terraces between Point Conception and Gaviota, western Transverse Ranges, California. In: Fletcher, C.H., III \& Wehmiller, J.F. (Eds), Quaternary Coasts of the United States: Marine and Lacustrine Systems. SEPM (Society for Sedimentary Geology) Special Publication, 48, pp. 333341.

Rodriguez, A.B., Anderson, J.B., Banfield, L.A., Taviani, M., Abdulah, K. \& Snow, J.N. (2000). Identification of $\mathrm{a}-15 \mathrm{~m}$ middle Wisconsin shoreline on the Texas inner continental shelf. Palaeogeography, Palaeoclimatology, Palaeoecology, 158, 25-43.
Rosholt, J.N., Jr., Emiliani, C., Geiss, J., Koczy, F.F. \& Wangersky, P.J. (1961). Absolute dating of deep-sea cores by the $\mathrm{Pa}^{231} / \mathrm{Th}^{230}$ method. Journal of Geology, 69 , $162-185$.

Rubin, K.H., Fletcher, C.H., III \& Sherman, C. (2000). Fossiliferous Lana'i deposits formed by multiple events rather than a single giant tsunami. Nature, 408, 675-681.

Sarna-Wojcicki, A.M., Lajoie, K.R. \& Yerkes, R.F. (1987). Recurrent Holocene displacement on the Javon Canyon fault - A comparison of fault-movement history with calculated average recurrence intervals. U.S. Geological Survey Professional Paper 1339, pp. 125-135.

Schroeder, W.W., Schultz, A.W. \& Pilkey, O.H. (1995). Late Quaternary oyster shells and sea-level history, inner shelf, northeast Gulf of Mexico. Journal of Coastal Research, 11, 664-674.

Shackleton, N.J. (1987). Oxygen isotopes, ice volume and sea level. Quaternary Science Reviews, 6, 183-190.

Shackleton, N.J. (2000). The 100,000-year ice-age cycle identified and found to lag temperature, carbon dioxide, and orbital eccentricity. Science, 289, 1897-1902.

Shepard, F.P. (1973). Submarine geology. New York, Harper and Row, $517 \mathrm{pp}$.

Sheridan, R.E., Ashley, G.M., Miller, K.G., Waldner, J.S., Hall, D.W. \& Uptegrove, J. (2000). Offshore-onshore correlation of upper Pleistocene strata, New Jersey coastal plain to continental shelf and slope. Sedimentary Geology, 134, 197-207.

Sherman, C.E., Fletcher, C.H. \& Rubin, K.H. (1999). Marine and meteoric diagenesis of Pleistocene carbonates from a nearshore submarine terrace, Oahu, Hawaii. Journal of Sedimentary Research, 69, 1083-1097.

Sherman, C.E., Glenn, C.R., Jones, A.T., Burnett, W.C. \& Schwarcz, H.P. (1993). New evidence for two highstands of the sea during the last interglacial, oxygen isotope substage 5e. Geology, 21, 1079-1082.

Shinn, E.A., Lidz, B.H., Kindinger, J.L., Hudson, J.H. \& Halley, R.B. (1989). Reefs of Florida and the Dry Tortugas: A guide to the modern carbonate environments of the Florida Keys and the Dry Tortugas. St. Petersburg, Florida, U.S. Geological Survey, $53 \mathrm{pp}$.

Simmons, K.R., Wehmiller, J.F., Krantz, D.E., Ludwig, K., Markewich, H.W., Rich, F. \& Hulbert, R.C., Jr. (1997). TIMS U-series ages for Atlantic coastal plain corals suggest $80 \mathrm{ka}$ sea level similar to the present. EOS, Transactions American Geophysical Union, 78, 46, F788. Snyder, S.W., Snyder, Stephen W., Riggs, S.R. \& Hine, A.C. (1991). Sequence stratigraphy of Miocene deposits, North Carolina continental margin. In: Horton, J.W., Jr. \& Zullo, V.A. (Eds), The Geology of the Carolinas. Knoxville, University of Tennessee Press, pp. 263-273.

Soller, D.R. \& Mills, H.H. (1991). Surficial geology and geomorphology. In: Horton, J.W., Jr. \& Zullo, V.A. (Eds), The Geology of the Carolinas. Knoxville, University of Tennessee Press, pp. 290-308.

Stanley, S.M. (1966). Paleoecology and diagenesis of Key Largo Limestone, Florida. Bulletin of the American Association of Petroleum Geologists, 50, 1927-1947. 
Stearns, H.T. (1938). Ancient shorelines on the island of Lanai, Hawaii. Geological Society of America Bulletin, 49, 615-628.

Stearns, H.T. (1974). Submerged shorelines and shelves in the Hawaiian Islands and a revision of some of the eustatic emerged shorelines. Geological Society of America Bulletin, 85, 795-804.

Stearns, H.T. (1978). Quaternary shorelines in the Hawaiian Islands. Bernice P. Bishop Museum Bulletin, 237, 57.

Stein, M., Wasserburg, G.J., Lajoie, K.R. \& Chen, J.H. (1991). U-series ages of solitary corals from the California coast by mass spectrometry. Geochimica et Cosmochimica Acta, 55, 3709-3722.

Stirling, C.H., Esat, T.M., Lambeck, K., McCulloch, M.T., Blake, S.G., Lee, D.-C. \& Halliday, A.N. (2001). Orbital forcing of the marine isotope stage 9 interglacial. Science, 291, 290-293.

Stuiver, M., Reimer, P.J., Bard, E., Beck, J.W., Burr, G.S., Hughen, K.A., Kromer, B., McCormac, G., van der Plicht, J. \& Spurk, M. (1998). INTCAL 98 Radiocarbon age calibration, 24,000-0 cal BP. Radiocarbon, 40, 1041-1083.

Suter, J.R., Berryhill, H.L., Jr. \& Penland, S. (1987). Late Quaternary sea-level fluctuations and depositional sequences, southwest Louisiana continental shelf. In: Nummendal, D., Pilkey, O.H. \& Howard, J.D. (Eds), Sea-Level Fluctuation and Coastal Evolution. SEPM (Society for Sedimentary Geology) Special Publication, 41, pp. 199-219.

Szabo, B.J. (1985). Uranium-series dating of fossil corals from marine sediments of southeastern United States Atlantic Coastal Plain. Geological Society of America Bulletin, 96, 398-406.

Szabo, B.J., Ludwig, K.R., Muhs, D.R. \& Simmons, K.R. (1994). Thorium-230 ages of corals and duration of the last interglacial sea-level high stand on Oahu, Hawaii. Science, 266, 93-96.

Taylor, F.W. \& Mann, P. (1991). Late Quaternary folding of coral reef terraces, Barbados. Geology, 19, 103-106.

Toscano, M.A. (1992). Record of oxygen isotope stage 5 on the Maryland inner shelf and Atlantic coastal plain a post-transgressive-highstand regime. In: Fletcher, C.H., III \& Wehmiller, J.F. (Eds), Quaternary Coasts of the United States: Marine and Lacustrine Systems. SEPM (Society for Sedimentary Geology) Special Publication, 48, pp. 89-100.

Toscano, M.A. \& Lundberg, J. (1998). Early Holocene sealevel record from submerged fossil reefs on the southeast Florida margin. Geology, 26, 255-258.

Toscano, M.A. \& Lundberg, J. (1999). Submerged late Pleistocene reefs on the tectonically-stable S.E. Florida margin: high-precision geochronology, stratigraphy, resolution of Substage 5a sea-level elevation, and orbital forcing. Quaternary Science Reviews, 18, 753-767.

Toscano, M.A. \& York, L.L. (1992). Quaternary stratigraphy and sea-level history of the U.S. Middle Atlantic Coastal Plain. Quaternary Science Reviews, 11, 301-328.

Trecker, M.A., Gurrola, L.D. \& Keller, E.A. (1998). Oxygenisotope correlation of marine terraces and uplift of the Mesa Hills, Santa Barbara, California, USA. In: Stewart, I.S. \&
Vita-Finzi,C.(Eds), Coastal Tectonics.London: Geological Society of London Special Publications, 146, pp. 57-69.

Valentine, J.W. (1958). Late Pleistocene megafauna of Cayucos, California and its zoogeographic significance. Journal of Paleontology, 32, 687-696.

Valentine, J.W. (1961). Paleoecologic molluscan geography of the Californian Pleistocene. University of California Publications in Geological Sciences, 34, 309-442.

Valentine, J.W. \& Veeh, H.H. (1969). Radiometric ages of Pleistocene terraces from San Nicolas Island, California. Geological Society of America Bulletin, 80, 1415-1418.

Vedder, J.G. \& Norris, R.M. (1963). Geology of San Nicolas Island California. U.S. Geological Survey Professional Paper, 369, 65 pp.

Veeh, H.H. (1966). $\mathrm{Th}^{230} / \mathrm{U}^{238}$ and $\mathrm{U}^{234} / \mathrm{U}^{238}$ ages of Pleistocene high sea level stand. Journal of Geophysical Research, 71, 3379-3386.

Veeh, H.H. \& Chappell, J. (1970). Astronomical theory of climatic change: Support from New Guinea. Science, 167, 862-865.

Veeh, H.H. \& Valentine, J.W. (1967). Radiometric ages of Pleistocene fossils from Cayucos, California. Geological Society of America Bulletin, 78, 547-550.

Wahrhaftig, C. \& Birman, J.H. (1965). The Quaternary of the Pacific mountain system in California. In: Wright, H.E., Jr. \& Frey, D.G. (Eds), The Quaternary of the United States. Princeton, Princeton University Press, pp. 299-340.

Walcott, R.I. (1972). Past sea levels, eustasy and deformation of the Earth. Quaternary Research, 2, 1-14.

Ward, L.W, Bailey, R.H. \& Carter, J.G. (1991). Pliocene and early Pleistocene stratigraphy, depositional history, and molluscan paleobiogeography of the coastal plain. In: Horton, J.W., Jr. \& Zullo, V.A. (Eds), The Geology of the Carolinas. Knoxville, University of Tennessee Press, pp. 274-289.

Wehmiller, J.F. (1982). A review of amino acid racemization studies in Quaternary mollusks: stratigraphic and chronologic applications in coastal and interglacial sites, Pacific and Atlantic coasts, United States, United Kingdom, Baffin Island, and tropical islands. Quaternary Science Reviews, 1, 83-120.

Wehmiller, J.F. (1992). Aminostratigraphy of Southern California Quaternary marine terraces. In: Fletcher, C.H., III \& Wehmiller, J.F. (Eds), Quaternary Coasts of the United States: Marine and Lacustrine Systems. SEPM (Society for Sedimentary Geology) Special Publication, 48, pp. 317-321.

Wehmiller, J.F. \& Belknap, D.F. (1978). Alternative kinetic models for the interpretation of amino acid enantiomeric ratios in Pleistocene mollusks: examples from California, Washington, and Florida. Quaternary Research, 9, 330-348.

Wehmiller, J.F. \& Belknap, D.F. (1982). Amino acid age estimates, Quaternary Atlantic coastal plain: comparison with U-series dates, biostratigraphy, and paleomagnetic control. Quaternary Research, 18, 311-336.

Wehmiller, J.F. \& Miller, G.H. (2000). Aminostratigraphic dating methods in Quaternary geology. In: Noller, J.S., Sowers, J.M. \& Lettis, W.R. (Eds), Quaternary 
Geochronology, Methods and Applications. American Geophysical Union Reference Shelf, 4, 187-222.

Wehmiller, J.F. \& York, L.L. (2001). Chronostratigraphic and paleoclimatic implications of paired radiocarbon/racemization analyses of Quaternary mollusks from the mid- and southeastern Atlantic coastal plain. Geological Society of America Abstracts with Programs, 33, 6, 171.

Wehmiller, J.F., Belknap, D.F., Boutin, B.S., Mirecki, J.E., Rahaim, S.D. \& York, L.L. (1988). A review of the aminostratigraphy of Quaternary mollusks from United States Atlantic Coastal Plain sites. Geological Society of America Special Paper, 227, pp. 69-110.

Wehmiller, J.F., York, L.L., Belknap, D.F. \& Snyder, S.W. (1992). Aminostratigraphic discontinuities in the U.S. Atlantic coastal plain and their relation to preserved Quaternary stratigraphic records. Quaternary Research, 38, 275-291.

Wehmiller, J.F., York, L.L., Krantz, D.E., \& Gayes, P.T. (1993). Aminostratigraphy of the Wando Fm., Charleston, S.C.: When is an aminozone a valid chronostratigraphic unit? Geological Society of America Abstracts with Programs, 25, 4, 76.

Wehmiller, J.F., York, L.L. \& Bart, M.L. (1995). Amino acid racemization geochronology of reworked Quaternary mollusks on U.S. Atlantic coast beaches: Implications for chronostratigraphy, taphonomy, and coastal sediment transport. Marine Geology, 124, 303-337.

Wehmiller, J.F., Otvos, E., Wingard, G.L. \& Scott, T.M. (1996). Aminostratigraphy of the Gulf Coast Quaternary approaches to correlation of aminozones between Atlantic and Pacific coast sites. Geological Society of America Abstracts with Programs, 28, 2, 49.

Wehmiller, J.F., Krantz, D.E., Simmons, K.R., Ludwig, K.R., Markewich, H.W., Rich, F. \& Hulbert, R.C., Jr. (1997). U.S. Atlantic Coastal Plain late Quaternary geochronology; TIMS U-series coral dates continue to indicate $80 \mathrm{kyr}$ sea level at or above present. Geological Society of America Abstracts with Programs, 29, 6, 346.

Wehmiller, J.F., York L.L., Jones, D.S.\& Portell, R.W. (1999). Racemization isochrons for the U.S. Atlantic coastal plain Quaternary: independent calibration and geochemical implications of results from marginal marine units, central Florida. V.M. Goldschmidt Geochemistry Conference Proceedings Volume, Cambridge, Massachusetts, p. 321.

Wehmiller, J.F., Rodriquez, A.B., Anderson, J.B. \& York, L.L. (2000a). Gulf of Mexico (east Texas inner shelf) Quaternary geochronology based on marine mollusk amino acid racemization data. EOS, Transactions American Geophysical Union, 81, 48, F650.

Wehmiller, J.F., Stecher, H.A., III, York, L.L. \& Friedman, I. (2000b). The thermal environment of fossils: effective ground temperatures (1994-1998) at aminostratigraphic sites, U.S. Atlantic coastal plain. In: Goodfriend, G.A., Collins, M.J., Fogel, M.L., Macko, S.A. \& Wehmiller, J.F. (Eds), Perspectives in Amino Acid and Protein Geochemistry. Oxford, Oxford University Press, pp. 219-250.
Wehmiller, J.F., Lajoie, K.R., Kvenvolden, K.A., Peterson, E., Belknap, D.F., Kennedy, G.L., Addicott, W.O., Vedder, J.G. \& Wright, R.W. (1977). Correlation and chronology of Pacific coast marine terrace deposits of continental United States by fossil amino acid stereochemistry - Technique evaluation, relative ages, kinetic model ages, and geologic implications. U.S. Geological Survey Open-File Report 77-680, $196 \mathrm{pp}$.

Winker, C.D. \& Howard, J.D. (1977). Correlation of tectonically deformed shorelines on the southern Atlantic coastal plain. Geology, 5, 123-127.

Winograd, I.J., Landwehr, J.M., Ludwig, K.R., Coplen, T.B. \& Riggs, A.C. (1997). Duration and structure of the past four interglaciations. Quaternary Research, 48, 141-154.

Woodring, W.P., Bramlette, M.N. \& Kew, W.S.W. (1946). Geology and paleontology of Palos Verdes Hills, California. U.S. Geological Survey Professional Paper 207, 145 pp.

Woodroffe, C.D., Short, S.A., Stoddart, D.R., Spencer, T. \& Harmon, R.S. (1991). Stratigraphy and chronology of late Pleistocene reefs in the southern Cook Islands, south Pacific. Quaternary Research, 35, 246-263.

Yokoyama, Y., De Deckker, P., Lambeck, K., Johnston, P. \& Fifield, L.K. (2001). Sea-level at the Last Glacial Maximum: Evidence from northwestern Australia to constrain ice volumes for oxygen isotope stage 2. Palaeogeography, Palaeoclimatology, Palaeoecology, 165, 281-297.

York, L.L. \& Wehmiller, J.F. (1992a). Molluscan aminostratigraphy of Pleistocene marine deposits offshore of Cape Fear, N.C. and Murrells Inlet, S.C. Geological Society of America Abstracts with Programs, 24, 2, 74.

York, L.L. \& Wehmiller, J.F. (1992b). Aminostratigraphic results from Cape Lookout, N.C. and their relation to the preserved Quaternary marine record of SE North Carolina. Sedimentary Geology, 80, 279-291.

York, L.L., Wehmiller, J.F., Cronin, T.M. \& Ager, T.A. (1989). Stetson Pit, Dare County, North Carolina: An integrated chronologic, faunal, and floral record of subsurface coastal sediments. Palaeogeography, Palaeoclimatology, Palaeoecology, 72, 115-132.

York, L.L., Harris, M.S., Wehmiller, J.F. \& Krantz, D.E. (1999). Implications of TIMS U-series dates for the Late Pleistocene sea level and aminostratigraphic record in the Coastal Plain of central South Carolina. EOS, Transactions of the American Geophysical Union, 80, 46, F585.

York, L.L., Jones, D.S., Martin, E.E., Portell, R.W. \& Wehmiller, J.F. (2000a). Comparison of strontium isotope and amino acid age estimates for Plio-Pleistocene mollusks, Central Florida. Geological Society of America Abstracts with Programs, 32, 7, 20.

York, L.L., Thieler, E.R., Brill, A.L., Riggs, S.R. \& Wehmiller, J.F. (2000b). Aminostratigraphic age estimate for the Suffolk Scarp, North Carolina Coastal plain. Geological Society of America Abstracts with Programs, 32, 2, 85.

York, L.L., Doar, W.R., III \& Wehmiller, J.F. (2001). Late Quaternary aminostratigraphy and geochronology of the St. Helena island area, South Carolina coastal plain. Geological Society of America Abstracts with Programs, 33, 2, 26. 